\title{
Stratigraphic and temporal context and faunal diversity of Permian-Jurassic continental tetrapod assemblages from the Fundy rift basin, eastern Canada
}

\author{
Hans-Dieter Sues $^{1 *}$ and Paul E. Olsen ${ }^{2}$ \\ 1. Department of Paleobiology, National Museum of Natural History, Smithsonian Institution, \\ MRC 121, P.O. Box 37012, Washington, DC 20013-7012, U.S.A. \\ 2. Lamont-Doherty Earth Observatory of Columbia University, 61 Route 9W, Palisades, \\ New York 10964-1000, U.S.A. \\ ${ }^{\star}$ Corresponding author: $<$ suesh@si.edu $>$
}

Date received 30 July 2014 Date accepted 25 November 2014

\begin{abstract}
The Fundy basin in Nova Scotia and New Brunswick is the largest exposed rift basin of the Newark Supergroup and also extends beneath the Bay of Fundy. Its strata can be divided into four tectonostratigraphic sequences (TS). TS I is represented by the probably Permian Honeycomb Point Formation and possibly the Lepreau Formation. TS II includes the Wolfville Formation with the probably Middle Triassic Economy Member and the early Late Triassic Evangeline Member. These members have yielded markedly different assemblages of continental tetrapods. TS III comprises most of the Blomidon Formation, which is Norian to Rhaetian in age. The Blomidon Formation has yielded few skeletal remains of tetrapods to date but many tetrapod tracks. TS IV includes the late Rhaetian top of the Blomidon Formation and the McCoy Brook Formation, which overlies the North Mountain Basalt and is latest Rhaetian and earliest Jurassic (Hettangian) in age. The McCoy Brook Formation has yielded a diversity of continental tetrapods and lacks any of the characteristic Late Triassic forms. Recent work has correlated the Global Boundary Stratotype Section and Point (GSSP) for the base of the Jurassic (Hettangian) to a level above the North Mountain Basalt. Thus most of the tetrapod fossils from the McCoy Brook Formation are latest Rhaetian in age, but the higher horizon with skeletal remains of sauropodomorph dinosaurs may be earliest Hettangian in age. The Fundy basin preserves the only known, stratigraphically tightly constrained record of the profound biotic changes in continental ecosystems across the Triassic-Jurassic transition.
\end{abstract}

\section{RÉSUMÉ}

Le bassin de Fundy, situé en Nouvelle-Écosse et au Nouveau-Brunswick et seetendant sous la baie de Fundy, est le plus important bassin d’effondrement exposé du supergroupe de Newark. Sa strate se divise en quatre séquences tectonostratigraphiques (ST). La première est représentée par la formation de Honeycomb Point, datant vraisemblablement du Permien, et peut-être par la formation de Lepreau. La deuxième comprend la formation de Wolfville ainsi que le membre d'Economy, datant vraisemblablement du Trias moyen, et le membre d'Evangeline, 
datant du début du Trias tardif. On a observé dans ces membres des assemblages sensiblement différents de tétrapodes continentaux. La troisième ST englobe la majeure partie de la formation de Blomidon, qui date du Norien au Rhétien. Jusqu'ici, on a observé dans cette formation peu de restes de tétrapodes, mais beaucoup de traces de ces animaux. Enfin, la quatrième ST comprend le dessus de la formation de Blomidon, qui date du Rhétien tardif, et la formation de McCoy Brook, qui recouvre le basalte du mont Nord et est âgé du Rhétien le plus tardif et du Jurassique le plus précoce (Hettangien). On a observé divers tétrapodes continentaux dans la formation de McCoy Brook, qui ne présente aucune des caractéristiques attribuables au Trias tardif. De récents travaux ont lié le point stratotypique mondial (PSM) établi pour le premier étage du Jurassique (Hettangien) à un niveau supérieur au basalte du mont Nord. Ainsi, la plupart des fossiles de tétrapode relevés dans la formation de McCoy Brook datent du Rhétien le plus tardif, mais l'horizon supérieur, qui présente des restes de dinosaure sauropodomorphe, pourrait dater de l'Hettangien le plus précoce. Le bassin de Fundy est le seul témoin connu soumis à un contrôle stratigraphique strict des profonds changements biotiques survenus dans les écosystèmes continentaux pendant la transition du Trias au Jurassique.

[Traduit par la redaction]

\section{INTRODUCTION}

The early Mesozoic was a time of extreme geography and climate. The supercontinent Pangaea nearly symmetrically straddled the palaeoequator (Fig. 1). With no evidence of polar ice (Sellwood and Valdes 2006), this 'hothouse' world was marked by coal deposition in polar and equatorial regions and by arid conditions in subtropical regions. Soil carbonate $\mathrm{CO}_{2}$ proxies from eastern North American rift basins and elsewhere indicate that Late Triassic background concentrations of atmospheric $\mathrm{CO}_{2}$ were between 2000 and 3000 ppm (Tanner et al. 2001; Schaller et al. 2011, 2012), whereas the leaf stomata $\mathrm{CO}_{2}$ proxies yield lower, but still impressive, concentrations of about $1000 \mathrm{ppm}$ (McElwain et al. 1999; Steinthorsdottir et al. 2011). Despite vast climatic differences compared to the present day there existed a humid equatorial zone of apparently modern dimensions (Kent and Olsen 2000). As Pangaea drifted northward, the Fundy basin passed through the transition zone between this humid region and the arid subtropics to the north, recording the Triassic-Jurassic transition and temporally adjacent events.

The material referred to in this paper is lodged at several institutions, referred to by abbreviations as follows: FGM, Fundy Geological Museum, Parrsboro, Nova Scotia, Canada; MCZ, Museum of Comparative Zoology, Harvard University, Cambridge, Massachusetts, U.S.A.; NSM, Nova Scotia Museum of Natural History, Halifax, Nova Scotia, Canada; ROM, Royal Ontario Museum, Toronto, Ontario, Canada; and YPM VPPU, former vertebrate palaeontology collection of the Museum of Natural History of Princeton University, now housed at the Peabody Museum of Natural History, Yale University, New Haven, Connecticut, U.S.A.

\section{Historical background}

The Canadian Maritimes have a long tradition of geological research. The eminent Canadian geologist John William Dawson was the first to study the geological structure of the region, especially of his home province of Nova Scotia, in a systematic fashion; he also pioneered the collection of fossils from a wide range of strata and localities.
On a field trip with Charles Lyell, Dawson discovered the now-famous occurrence of tetrapods within stumps of Pennsylvanian-age arborescent lycopsids at Joggins, Nova Scotia, in 1852. Later he summarized his observations, as well as data from other researchers, in his classic Acadian Geology, which went through four editions between 1855 and 1891 (Dawson 1855, 1891). Dawson was first to illustrate the complex outcrops of the Triassic-Jurassic rocks along the

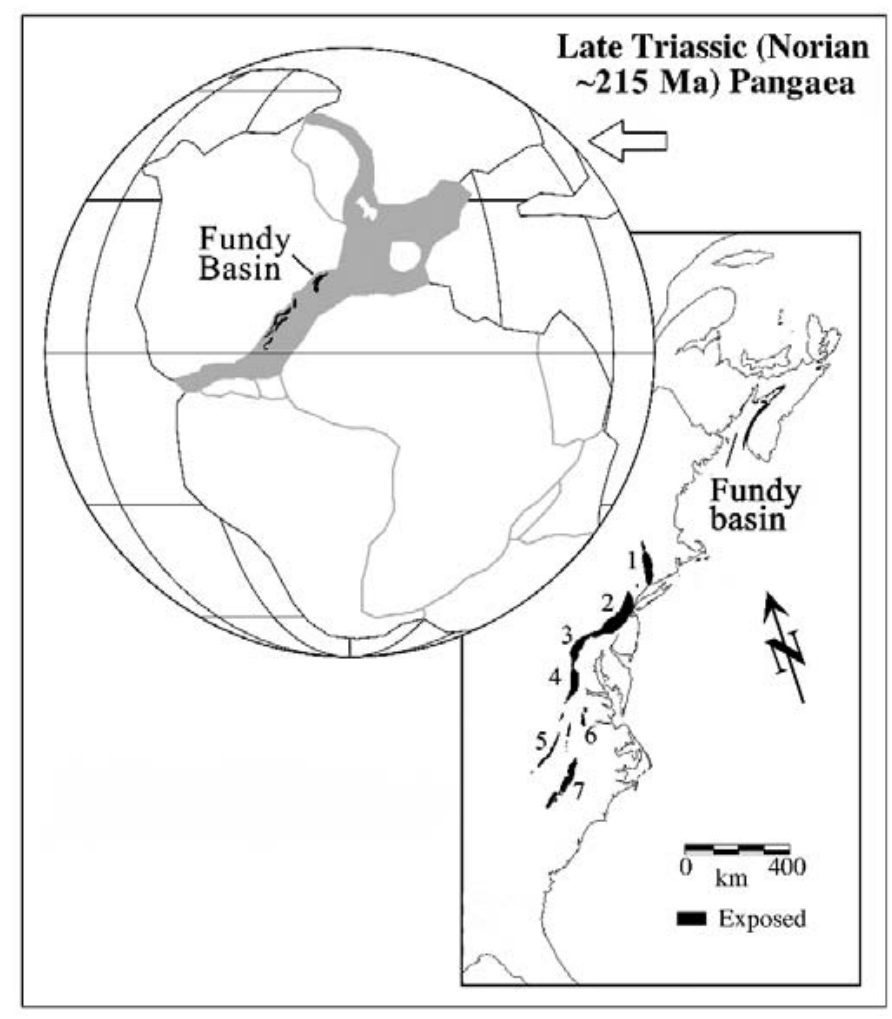

Figure 1. Location of the Fundy basin in Pangaea and eastern North America. The following other major basins of the Newark Supergroup are also indicated: 1, HartfordDeerfield; 2, Newark; 3, Gettysburg; 4, Culpeper; 5, Dan River-Danville; 6, Richmond-Taylorsville; 7, Deep River. Based on Olsen et al. (1996). 
northern shores of the Minas Basin, including Wasson Bluff, a locality that would prove critical to understanding the Triassic-Jurassic transition in continental biotas worldwide.

The next major contribution of significance was the study of the "Acadian Triassic" in Nova Scotia and New Brunswick by Sidney Powers, which resulted in a doctoral dissertation at Harvard University (Powers 1915, 1916). Based on his own extensive fieldwork and careful review of earlier studies, Powers laid the foundation for all subsequent research.

In the late 1950s William Take, then Curator of Geology at the Nova Scotia Museum of Science in Halifax, was the first to discover vertebrate fossils in exposures of the Triassic Wolfville Formation in Hants County, Nova Scotia, in what we term the Evangeline Member (see below). In late 1958 he showed his finds to Donald Baird, then Curator at the Museum of Natural History at Princeton University. Baird and Take followed up on the latter's discovery and collected additional vertebrate remains and other fossils from the Wolfville Formation in 1959 and 1960 (Baird and Take 1959). Although their collaboration did not continue after 1960, Baird continued to collect material from the Wolfville Formation until 1985 (Baird 1963; Baird and Olsen 1983; Sues et al. 2013). In August 1966, Baird discovered another occurrence of Triassic vertebrate fossils near Lower Economy in Colchester County, Nova Scotia, in what we identify here as the Economy Member (see below). Although most of the material from this locality is dissociated and fragmentary, the composition of this faunal assemblage is distinct from that collected by Baird and Take from the Wolfville Formation along the southern margin of the Minas Basin. Baird later collaborated with other researchers to prepare a detailed guidebook for a field excursion to key localities with fossil vertebrates in eastern Canada for the Twenty-Fourth International Geological Congress (Carroll et al. 1972).

Although Baird never published extensively on his discoveries of early Mesozoic tetrapod fossils in Nova Scotia and New Brunswick, he kept meticulous records for most of his active research career, spanning the period from March 1953 through August 1998. In August 2011, Baird's son Andrew and the scientific executor of Baird's estate, Robert Hook, donated five notebooks to the Society of Vertebrate Paleontology Archive at the Smithsonian Institution Archives (SIA Accession Number 12-107) (Sues et al. 2013). These notebooks have continuous pagination, and thus we will cite them in the text as "(Baird MS, page number)".

In August 1976, one of us (PEO) discovered fragments of bone while prospecting exposures of the McCoy Brook Formation near Parrsboro, Cumberland County, Nova Scotia, while travelling with the Baird field party (Baird MS, pp. 574-575). When reassembled, this find proved to be a cervical vertebra of a sauropodomorph dinosaur. In 1984, PEO found a well-preserved partial skull of a sphenodontian reptile near the same spot. Over the years, various researchers, most recently Tim Fedak (Fundy Geological Museum), have collected additional skeletal remains of sauropodomorphs. PEO's discovery prompted a major research effort during the 1980s by teams from Columbia and Harvard universities led by himself and Neil Shubin. The result was the discovery of diverse vertebrates from aquatic to fully terrestrial depositional settings (Olsen et al. 1989, 2005a, b; Shubin et al. 1991, 1994; Sues et al. 1994, 1996). Subsequently, the present authors and others have continued to explore strata of the Wolfville Formation and have recovered numerous important new vertebrate fossils.

Both the published literature and media releases contain many erroneous statements concerning the early Mesozoic continental biotas from the Fundy region; often such statements have been based on cursory examination of unprepared material. This problem, combined with the broader significance of the tetrapod fossils of the Fundy basin - particularly for understanding the end-Triassic mass extinction (ETE) - has provided the impetus for the present review.

\section{Overall geological context}

The Fundy basin is the largest of the exposed rift basins in eastern North America, which together comprise the western part of the conjugate-margin rift system that formed during the Late Permian to Jurassic continental rifting phase of the breakup of Pangaea (Olsen et al. 2000, 2003a, b, 2005a, b; Olsen and Et-Touhami 2008; Fig. 1). The igneous and sedimentary fill of these rift basins represents the Newark Supergroup (Olsen 1978). Continental rifting probably commenced in eastern North America during the Permian, as documented by deposits in New Brunswick described below. It terminated in the Early Jurassic, within a few million years of the major tectonic paroxysm at the end of the Triassic that resulted in the emplacement of basaltic intrusions and extrusions of the Central Atlantic Magmatic Province (CAMP) (Marzoli et al. 1999; Olsen et al. 2003a; Blackburn et al. 2013), which is Earth's geographically most extensive flood-basalt province. The emplacement of CAMP is temporally, and possibly causally, related to the endTriassic extinction.

Structurally, the Fundy basin is a faulted and eroded half-graben, situated on the suture between the Avalon and Meguma terranes (Wade et al. 1996), both of which were accreted to the future North America during the Palaeozoic. It is bounded by the largely normal Fundy fault and Grand Manan fault systems on its northwestern and western sides and the transtensional Cobequid-Chedabucto (or Minas) fault system to the north (Fig. 2). All these systems are reactivated Palaeozoic fault zones (Withjack et al. 1995; McHone 2011). The southern and southeastern margins of 


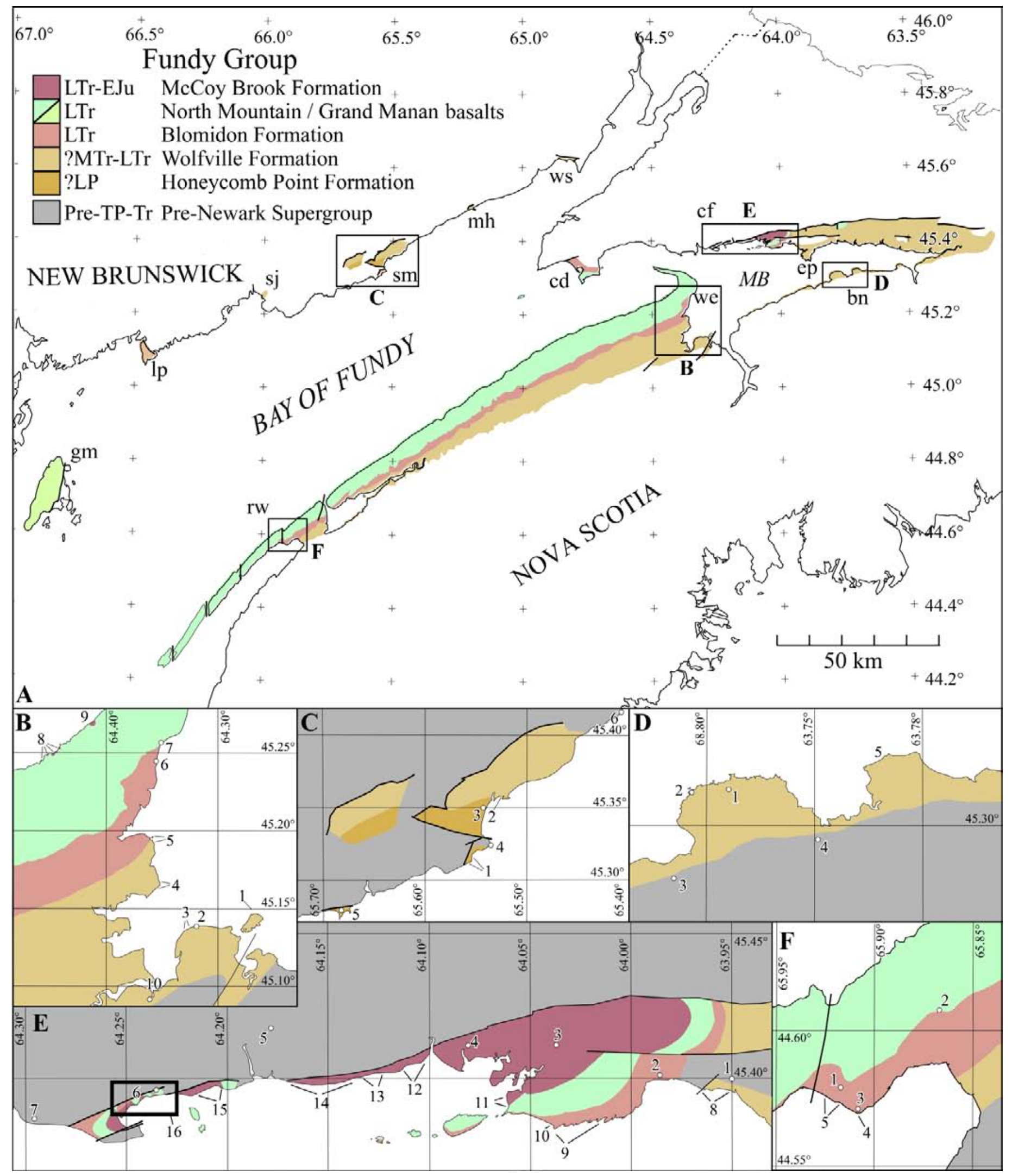


Figure 2. (previous page) Maps of localities in the Fundy basin. (A) Fundy basin. Abbreviations: bn, Burntcoat-Noel Head area; cd, Cape d'Or area; cf, Cape Sharp to Five Islands area; ep, Economy peninsula area; gm, Grand Manan area; lp, Lepreau area; MB, Minas Basin; mh, Martin Head area; rw, Rossway area; sj, Saint John area; sm, St. Martins area; we, Wolfville-Evangeline Beach area; ws, Waterside area. (B) Wolfville-Evangeline Beach area (based on Moore et al. 2009): 1, Boot Island locality of Baird and type locality of Scoloparia glyphanodon (Sues and Baird 1998); 2, Evangeline Beach, Kings County; 3, type section of the Evangeline Member of the Wolfville Formation; 4, outcrops at Longspell Point, Kingston, Kings County; 5, outcrops in vicinity of Paddy Island, Medford, Kings County; 6, Blomidon, Kings County; 7, type section of the White Water Member of the Blomidon Formation, White Water, Kings County; 8, coves with outcrops of the Scots Bay Member of the McCoy Brook Formation (from southwest to northeast: Woodworth Cove, Lime Cove, West Broad Cove and Central Broad Cove, East Broad Cove); 9, Davidson Cove with outcrops of the Scots Bay Member of the McCoy Brook Formation; 10, Wolfville, Kings County. (C) St. Martins area, New Brunswick (Barr and White 2005a, b): 1, Honeycomb Point footprint assemblage at Honeycomb Point; 2, “The Caves", St. Martins; 3, St. Martins, Saint John County; 4, Quaco Head, St. Martins; 5, Robinson Cove, 6, Salmon River, St. Martins, New Brunswick. (D) Burntcoat-Noel Head area, Hants County: 1, Burntcoat; 2, Burntcoat Head and lighthouse; 3, Minasville; 4, Noel; 5, Noel Shore. (E) Cape Sharp to Five Islands area: 1, Carrs Brook; 2, Lower Economy; 3, Five Islands; 4, Lower Five Islands; 5, Moose River; 6, Two Islands; 7, Riverside Beach; 8, location of the type section of the Economy Member of the Wolfville Formation and location of tetrapod remains; 9, location of the type section of the Red Head Member of the Blomidon Formation; 10, Red Head track locality; 11, Five Islands, McCoy Brook, footprint assemblage; 12, Blue Sac east footprint assemblage; 13, Blue Sac west, locality of cf. Protosuchus in basalt breccia; 14, Blue Sac west footprint assemblage; 15, McKay Head footprint assemblage; 16, Wasson Bluff area (see Fig. 28). (F) Rossway area, Digby County: 1, Rossway, Digby County; 2, Rossville, Digby County; 3, Red Head; 4, Red Head phytosaur locality; 5, Red Head footprint assemblage.

the basin are marked by onlap onto hanging-wall rocks of the Meguma terrane and overlying late Palaeozoic strata. The Fundy basin occupies an area about $16500 \mathrm{~km}^{2}$ and is largely covered today by the Bay of Fundy and its inner eastern arm, the Minas Basin. However, extensive outcrops of the basin deposits occur along the shores of west-central Nova Scotia and, to a much lesser extent, on the southeastern shores of New Brunswick. A thickness of at least $4 \mathrm{~km}$ of sedimentary and volcanic rocks is preserved in the deepest parts of the basin along the Fundy and Grand Manan fault zones based on industry seismic lines (Wade et al. 1996; McHone 2011). However, the entire section thins dramatically to the east and south towards the outcrops in Nova Scotia by convergence, onlap, non-deposition and erosion. Similarly, the sections of erosional remnants outcropping in New Brunswick, on the Fundy fault zone on footwall rider blocks, are either much thicker than correlative units on the hanging wall, or represent units unknown on the hanging wall. Along with the divergence of strata towards the Fundy and Grand Manan fault zones revealed by seismic profiles, two deep exploratory drill holes in the Bay of Fundy, and several much shallower cores on the Nova Scotian outcrop belt, the outcrops reflect the growth of the sedimentary basin during at least the early Mesozoic extension along the Fundy and Grand Manan fault zones (Withjack et al. 1995). At the same time much more complex syntectonic basin geometries developed along the transtensional Cobequid-Chedabucto fault system (Olsen et al. 1990).

A major outlier of early Mesozoic rocks crops out on the shores of Grand Manan Island, New Brunswick. McHone (2011) considered it a separate basin, and thus it will not be discussed further in the present paper.

\section{Stratigraphy and age of the Fundy basin}

Powers $(1915,1916)$ established an outline of the stratigraphy of the Fundy basin (Fig. 3) based on extensive fieldwork and review of older literature. He recognized three stratigraphic units:

(1) the basal Annapolis formation, divided informally into a lower, brown and red Wolfville sandstone and an upper, mostly red Blomidon shale; these two units were supposedly separated locally by the Five Islands volcanics;

(2) the lava flows of the North Mountain Basalt;

(3) the largely white and green cherty limestones of the Scots Bay Formation.

Klein $(1960,1962)$ abandoned the term Annapolis formation and established the Wolfville and Blomidon formations for Powers' lower and upper units, respectively. He used the term McKay Head Basalt for the basalt flows and volcanoclastics included by Powers in the supposedly intervening Five Islands volcanics. Klein also included all sedimentary and volcanic rocks of the Fundy basin in the Fundy Group.

Olsen (1978) raised the rank of the Newark Group of Redfield (1856) to Newark Supergroup, to encompass all early Mesozoic rocks of eastern North America, and thus including the Fundy Group. We chose not to apply the group nomenclature of Weems and Olsen (1997) in which the Fundy basin sequence is divided into a lower Chatham Group and an upper Meriden Group, both of which extend across eastern North America, because it requires an explicitly chronostratigraphic, as opposed to lithostratigraphic framework, and the interpreted regional similarities are conceptually better handled within a 


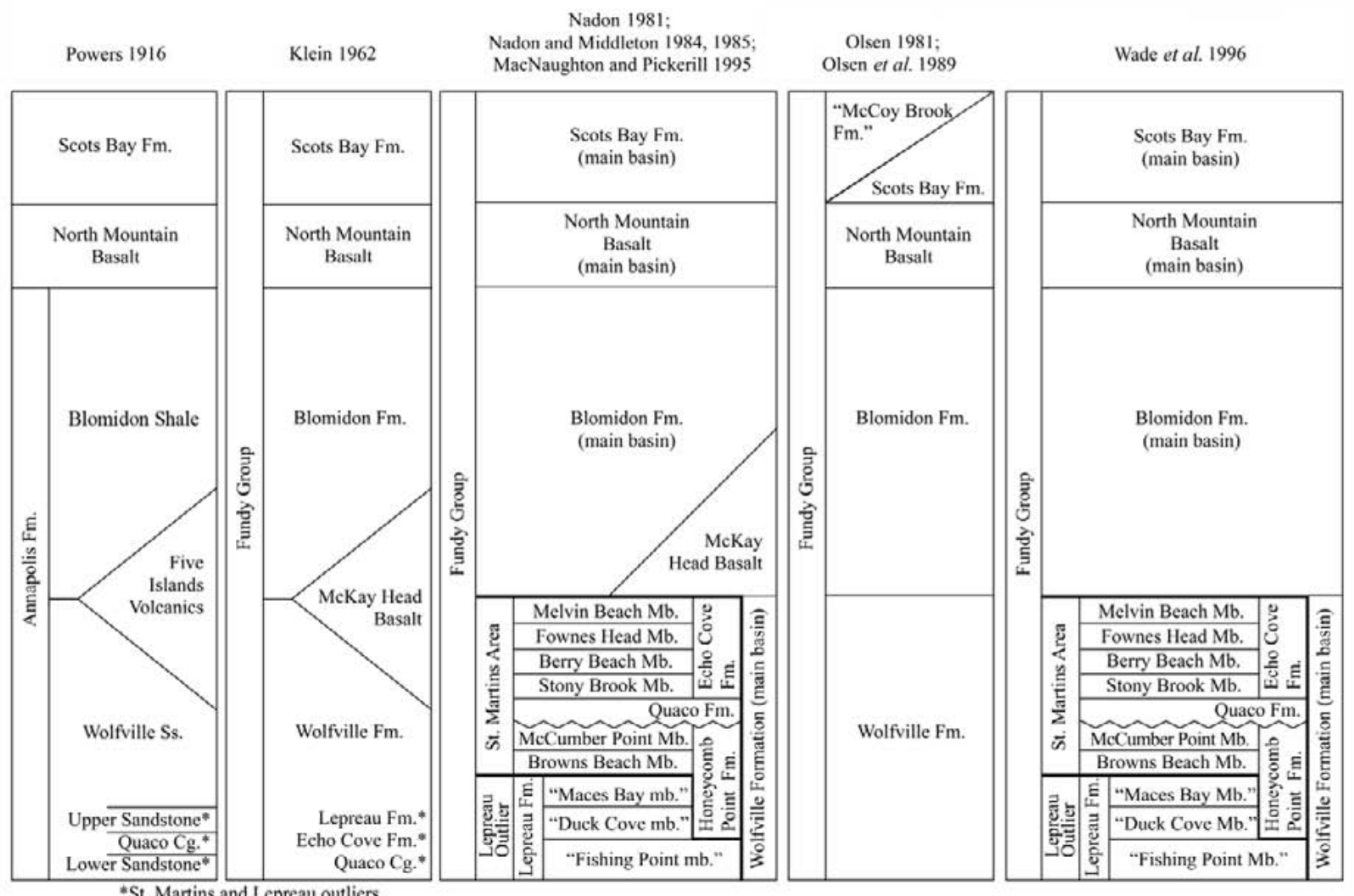

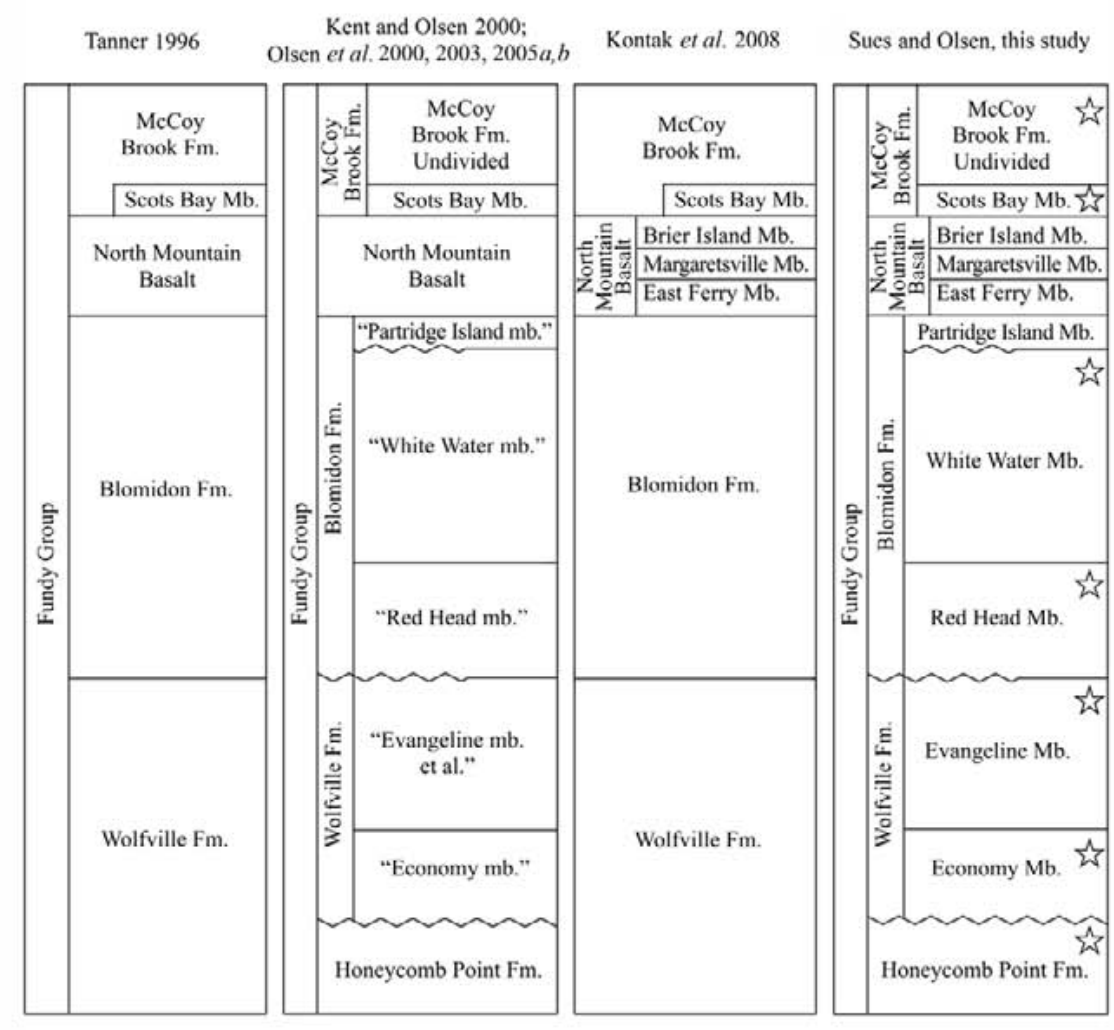

Figure 3. History of the stratigraphic nomenclature of the Fundy Group in the Fundy basin, Nova Scotia and New Brunswick. 
tectonostratigraphic framework (Olsen 1997).

Liew (1976) posited that the strata above the Five Islands volcanics of Powers (1916) were equivalent to the Scots Bay Formation. Using a combined biostratigraphic and facies argument, Olsen (1981) argued that the McKay Basalt and the Five Islands volcanics represent the same set of lava flows as the North Mountain Basalt, concurring with Liew. This interpretation has generally been followed (Stevens 1980, 1987; Williams et al. 1985; Tanner 1996), and the thick, mostly red sedimentary unit above the North Mountain Basalt was informally designated as the McCoy Brook formation on maps and in guidebooks (Donohoe and Wallace 1978, 1982: Keppie 1979: Olsen et al. 1989). Tanner (1996) formalized the McCoy Brook Formation, provided a type section (adjacent to McCoy Brook at McKay Head), and reclassified the Scots Bay Formation as a member of the McCoy Brook Formation.

Outliers of the Fundy Group occur along the Fundy coast of New Brunswick. As summarized by Luttrell (1989), these strata have a complex nomenclatural history, beginning with Powers (1916). We argue that, with two exceptions (Honeycomb Point and Lepreau formations), these units should be recognized as members of the Wolfville Formation (Figs. 3-5; Appendix). These units have yielded sparse and as yet poorly studied but potentially important faunal and floral assemblages.

Olsen et al. (2000) introduced informal names for palaeontologically important members of the Wolfville and Blomidon formations (Fig. 3). Here we formalize these units and provide type sections and brief descriptions (Appendix; Fig. 3). In ascending order, the formally defined units are the Economy and Evangeline members of the Wolfville Formation and the Red Head, White Water, and Partridge Island members of the Blomidon Formation.

The formations of the Fundy basin can be grouped into four tectonostratigraphic sequences (TS I to TS IV; Figs. 5-6), most of which are bounded by unconformities (Olsen 1997) and are thus sequences in the sense of sequence stratigraphy (Christie-Blick and Driscoll 1995). The sequences probably resulted from significant changes in the rate of extension, as opposed to changes in sea level (Olsen 1997). The oldest of these sequences, TS I, is represented by the Honeycomb Point Formation and possibly the Lepreau Formation, and is characterized by fluvial and aeolian strata of Late Permian age (Olsen et al. 2005a, b; see below). The Quaco Member of the Wolfville Formation unconformably overlies the Honeycomb Point Formation. The Wolfville Formation comprises TS II, of possibly Middle to early Late Triassic (Carnian) age based on biostratigraphy (see below), and consists of aeolian, fluvial and possibly lacustrine strata that seem to have been, on the whole, deposited under a more humid climatic regime than strata of TS I. At least locally, TS II is unconformably overlain by TS III, which comprises almost the entire Blomidon Formation. TS III was deposited under relatively arid climatic conditions and is of Norian and Rhaetian age. Its age is constrained by palaeomagnetic correlation to the Newark basin astrochronology and marine sequences (Kent and Olsen 1999; Muttoni et al. 2004; Olsen et al. 2011). TS IV conformably overlies TS III and consists of the late Rhaetian top member of the Blomidon Formation and (overlying the North Mountain Basalt) the McCoy Brook Formation, which is of latest Rhaetian to Hettangian (and possibly younger) age. The dating of the uppermost Blomidon Formation is based on biostratigraphy and palaeomagnetic polarity stratigraphy, whereas the North Mountain Basalt has yielded a series of increasingly more precise zircon ${ }^{206} \mathrm{~Pb} /{ }^{238} \mathrm{U}$ dates (Schoene et al. 2006, 2010) culminating with a chemical abrasion TIMS single-crystal U-Pb date of $201.566 \pm 0.031 \mathrm{Ma}$ (Blackburn et al. 2013). These latest dates are in addition to older K-Ar and ${ }^{40} \mathrm{Ar} /{ }^{39} \mathrm{Ar}$ (Carmichael and Palmer 1968; Armstrong and Besancon 1970; Hayatsu 1979) and zircon U-Pb (Hodych and Dunning 1992) dates. The age of the McCoy Brook Formation is constrained by that of the underlying North Mountain Basalt and by biostratigraphy (see below).

\section{FOSSIL ASSEMBLAGES: VERTEBRATE DIVERSITY AND BIOSTRATIGRAPHIC SIGNIFICANCE}

\section{Tectonostratigraphic Sequence I: Honeycomb Point and Lepreau formations}

The oldest unit of the Fundy Group, the Honeycomb Point Formation, outcrops in the vicinity of St. Martins, New Brunswick, and is the only part of the Group that definitively represents TS I (Fig. 5). To date, the Honeycomb Point Formation has yielded only silicified wood (Powers 1916), trace fossils and possible scraps of bone.

The first-recorded occurrence of tetrapod ichnofossils from the Honeycomb Point Formation is in Baird's field notes for 1959 (Baird MS, pp. 271, 276), in which he mentions footprints in the roof and on the base of the 'caves' at Macs Beach, St. Martins, New Brunswick $\left(45.357467^{\circ} \mathrm{N}\right.$, $65.523531^{\circ} \mathrm{W}$ ). William Take apparently first discovered some of these tracks. PEO also saw one example on the roof of the westernmost cave on a field trip with Baird in 1973 (Baird MS, p. 540), consisting of curved scratch marks in positive hyporelief. Unfortunately, there appear to be no photographic or other records of these occurrences, and PEO has not seen any tetrapod traces at this locality since that time.

Outcrops of Honeycomb Point Formation both east and west of Honeycomb Point proper have yielded a few tetrapod tracks (Olsen and Et-Touhami 2008; Fig. 7). These do not resemble any similar-sized ichnites from the other basins of the Newark Supergroup but are similar to Permian tetrapod ichnotaxa such as Dimetropus or Hyloidichnus in 

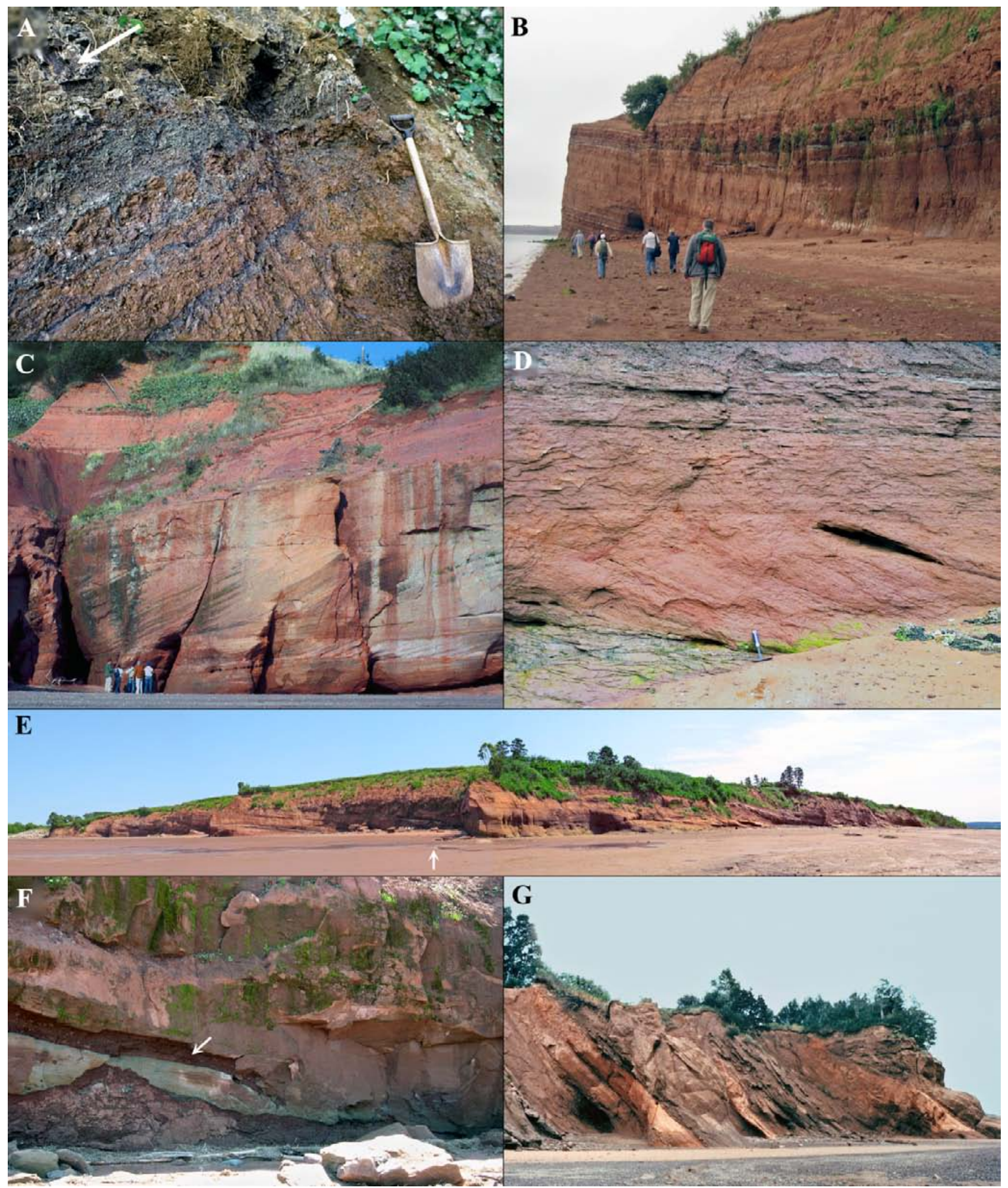
Figure 4. (previous page) Photos of the type sections of the members of the formations in the main Fundy basin (northern and southern shores of the Minas Basin). (A) Alternating red, grey and black mudstones of the type section of the Partridge Island Member of the Blomidon Formation; northwest side of Partridge Island, Cumberland County (arrow marks point to the contact with the overlying North Mountain Basalt; note the deep grey-in-red cracks in the upper part of the section); the shovel is $1 \mathrm{~m}$ long, and the view is to the south at $45.369377^{\circ} \mathrm{N}, 64.336279^{\circ} \mathrm{W}$. (B) Most of the upper third of the type section of the White Water Member of the Blomidon Formation, White Water, Blomidon Provincial Park, Kings County, Nova Scotia (the view is to the southwest from approximately $45.2499^{\circ} \mathrm{N}, 64.3530^{\circ} \mathrm{W}$ ). (C) Aeolian dune sandstones and fluvial sandstones and gravels, uppermost part of the type section of the Red Head Member of the Blomidon Formation, Five Island Provincial Park, Colchester County, Nova Scotia (the view is to the northeast from approximately $45.3834^{\circ} \mathrm{N}, 64.0386^{\circ} \mathrm{W}$ ). (D) Aeolian dune sandstones interbedded with fluvial sandstones, shore section of the Red Head Member of the Blomidon, Paddy Island area, North Medford, Kings County, Nova Scotia at $45.192333^{\circ} \mathrm{N}, 64.358000^{\circ} \mathrm{W}$ (length of hammer: $40 \mathrm{~cm}$ ). (E) Type section of the Evangeline Member of the Wolfville Formation, west part of Evangeline Beach, Grand Pré, Kings County, Nova Scotia (arrow points to position of detail in F) (view is to the south from about $45.1368^{\circ} \mathrm{N}, 64.3300^{\circ} \mathrm{W}$. (F) Portion of the type section of the Evangeline Member (marked by arrow in E) that produced the conchostracan Euestheria minuta (arrow points to a 50-cm-thick conchostracan-bearing unit at $45.135950^{\circ} \mathrm{N}, 64.329233^{\circ} \mathrm{W}$ ). (G) Portion of the type section of the Economy Member of the Wolfville Formation, Carrs Brook, Colchester County, Nova Scotia (view looking east from approximately $45.3962^{\circ} \mathrm{N}, 63.9621^{\circ} \mathrm{W}$ (see Appendix).

being markedly asymmetrical, with medially curved and expanded distal digit imprints. However, the Honeycomb Point tracks are not sufficiently well preserved for confident assignment to any particular ichnotaxon. Furthermore, these tracks are either not readily accessible or cannot be collected, being high on a cliff face in one case or on the underside of a very large boulder in another. Olsen and EtTouhami (2008, fig. 21) published a measured section with these occurrences.

The only possible tetrapod skeletal remains from the Honeycomb Point Formation are apparently unidentifiable fragments of bone that Baird recorded from the north side of Quaco Head in conglomerate and arkose in 1959 (Baird MS, p. 271). These finds were housed at the NSM in 1959, but their current repository is unknown. It is also uncertain whether these remains did in fact derive from the Honeycomb Formation because Carboniferous conglomerate and arkose also crop out at Quaco Head.

Based on published biostratigraphic information, the age of the Honeycomb Point Formation is uncertain. Olsen and Et-Touhami (2008) argued that this formation is Late Permian in age based on facies similarity to the Cap Aux Meules Formation of the Magdalen basin in the Gulf of St. Lawrence. The latter unit is constrained in age by unconformably overlying strata of Early Permian (Sakmarian) age and having a Permian pole position (Tanczyk 1988). Palaeomagnetic data from the Honeycomb Formation indicate largely reverse polarities, with higher strata being of mixed polarity; this is consistent with a Late Permian age (Olsen et al. 2000, 2002), but the details remain unpublished. The upper limit of the age of the Honeycomb Point Formation is based on palynological samples recovered from the unconformably overlying Wolfville Formation (formerly Echo Cove Formation) that indicate an early Late Triassic (Carnian) age. Finally, the tectonostratigraphcally homotaxial Ikakern Formation in Morocco is unquestionably Permian in age based on its vertebrate fossils and other biostratigraphic evidence (Jalil 1999; Jalil and Janvier 2005; Voigt et al. 2010) and can be correlated with the Honeycomb Point Formation based on preliminary palaeomagnetic polarity stratigraphy and pole positions (Olsen et al. 2002a).

The more than $2000 \mathrm{~m}$ thick Lepreau Formation (Fig. 2A), which crops out in an outlier at Lepreau, southwest of Saint John, New Brunswick, is of uncertain age. From an isolated outcrop at Lepreau Falls on the Lepreau River, Sarjeant and Stringer (1978) reported a small tetrapod trackway and referred it to the ichnotaxon Isocampe from the Hartford basin. Sarjeant and Stringer assigned the strata hosting the trackway to the Lepreau Formation and, based on their identification of Isocampe, dated them as Triassic. However, the trackway shows characters diagnostic only at the level of Tetrapoda and thus is not biostratigraphically useful. Subsequently, the strata at Lepreau Falls have been recognized as part of the Carboniferous Balls Lake Formation (McLeod and Johnson 1998; MacNaughton and Pickerill 2010). The main outcrop of the Lepreau Formation is of uncertain age, and no skeletal remains or tetrapod tracks have been reported from it.

\section{Tectonostratigraphic Sequence II: Wolfville Formation}

The Wolfville Formation represents TS II in the Fundy basin, and in it we group not only the Wolfville Formation sensu Klein (1962) but also the Quaco Formation (Powers 1916; Nadon and Middleton 1985) and Echo Cove Formation (Nadon and Middleton 1985) (Fig. 3). To date no tetrapod fossils have been reported from the Wolfville Formation of New Brunswick, and thus we will restrict our discussion primarily to exposures in Nova Scotia, 


\section{Fundy Group}

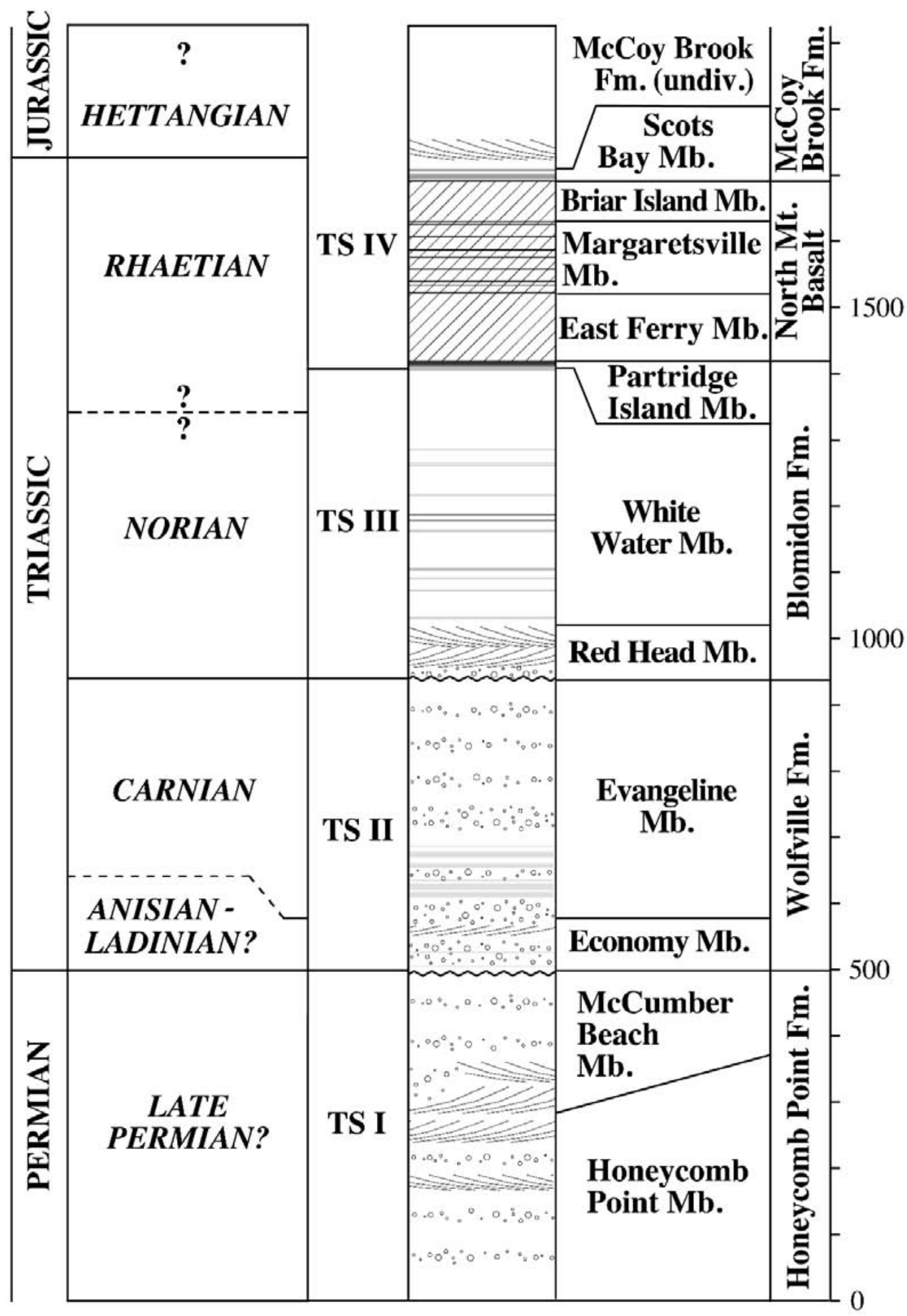

Figure 5. Stratigraphic scheme, tectonostratigraphic (TS) divisions, and age assignments for the Fundy Group in the Fundy basin, as used in this paper. 


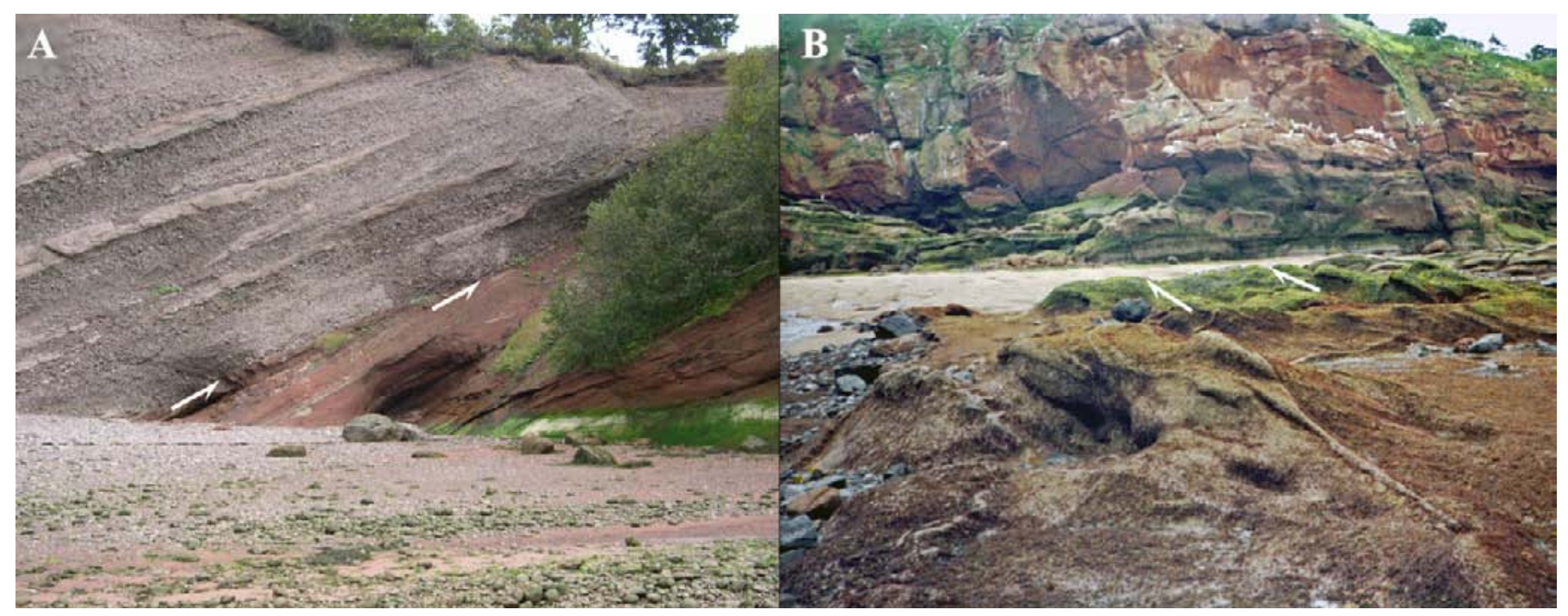

Figure 6. Examples of key tectonostratigraphic sequence boundaries in the Fundy basin. (A) TS I - TS II boundary, with the Quaco Member of the Wolfville Formation (TS II) unconformably overlying the McCumber Point Member of the Lepreau Formation (TS II) (“The Caves”, St. Martins, Saint John County, New Brunswick; $45.3580^{\circ} \mathrm{N}, 65.5236^{\circ}$ W). (B) TS II - TS III boundary, with fluvial and aeolian sandstones of the Red Head Member of the Blomidon unconformably overlying steeply dipping sandstones and conglomerates of the undifferentiated Wolfville Formation (Pinnacle Island, Five Islands, Cumberland County, Nova Scotia; $\left.45.3786^{\circ} \mathrm{N}, 64.1263^{\circ} \mathrm{W}\right)$. Arrows mark truncated bedding of the overlying units.

from which two distinct tetrapod assemblages have been identified: a stratigraphically older assemblage from the Economy Member and a younger one from the Evangeline Member (Fig. 5).

\section{Economy Member}

Strata of the Economy Member (defined in Appendix; Fig. 4G) consist largely of fluvial deposits interbedded with a few significant intervals of aeolian sandstone, which are generally absent in the rest of the Wolfville Formation. The type area at Lower Economy in Colchester County is in a structurally isolated block on the northern side of the Minas Basin. A very similar sequence, including aeolian strata, on the southern shore of the Minas Basin (Leleu et al. 2010) that we place in the Economy Member, is overlain by the middle Wolfville Formation (Evangeline Member) (see Appendix).

Starting in 1966, Donald Baird and his teams prospected coastal exposures of the Economy Member in the Lower Economy area (Fig. 8), recovering dissociated bones and teeth representing a considerable diversity of tetrapods. More recently PEO, Tim Fedak (Fundy Geological Museum) and others have collected additional vertebrate fossils from this section. Unfortunately, most specimens are too fragmentary to permit lower-level taxonomic identification and often even basic anatomical assessment. However, enough material has now been identified to establish that this tetrapod assemblage is distinct from other, younger assemblages in the Newark Supergroup and elsewhere.
Bones occur mostly as isolated clasts in fluvial, calcitecemented intraformational conglomerate and lithicclast, pebbly intraformational conglomerate, along with occasional unionoid bivalves (Fig. 8B). These deposits form dune-scale trough cross-beds.

Temnospondyl stem-amphibians from the Economy Member are referable to two groups, Capitosauroidea and Trematosauroidea, distinguishable on the basis of jaw fragments. The symphyseal portion of a large capitosauroid mandible (FGM998GF8) has a blunt anterior margin and a pair of tusks, followed behind by a row of smaller postsymphyseal teeth (Fig. 9A). The latter feature argues against referral of this jaw fragment to Mastodonsauridae, but it is present in certain other capitosauroids such as Parotosuchus (Schoch and Milner 2000). Additional capitosauroid remains include mandibular fragments (e.g., YPM VPPU 021692; Fig. 9B) and a small piece of the left postorbital region of a skull roof (YPM VPPU 023501).

Welles (1993) referred the trematosauroid cranial remains to the slender-snouted lonchorhynchine Cosgriffius, which was first reported from the Wupatki Member of the Moenkopi Formation (of Olenekian age) in Arizona. The remains reported by Welles include an incomplete left mandibular ramus with 78 preserved tooth positions, many of them still with partial tooth crowns (YPM VPPU 021691) (Fig. 9C). There are no diagnostic features to suggest that the material from the Economy Member is referable to Cosgriffius (as proposed by Welles) rather than another lonchorhynchine taxon. A fragment identified by 


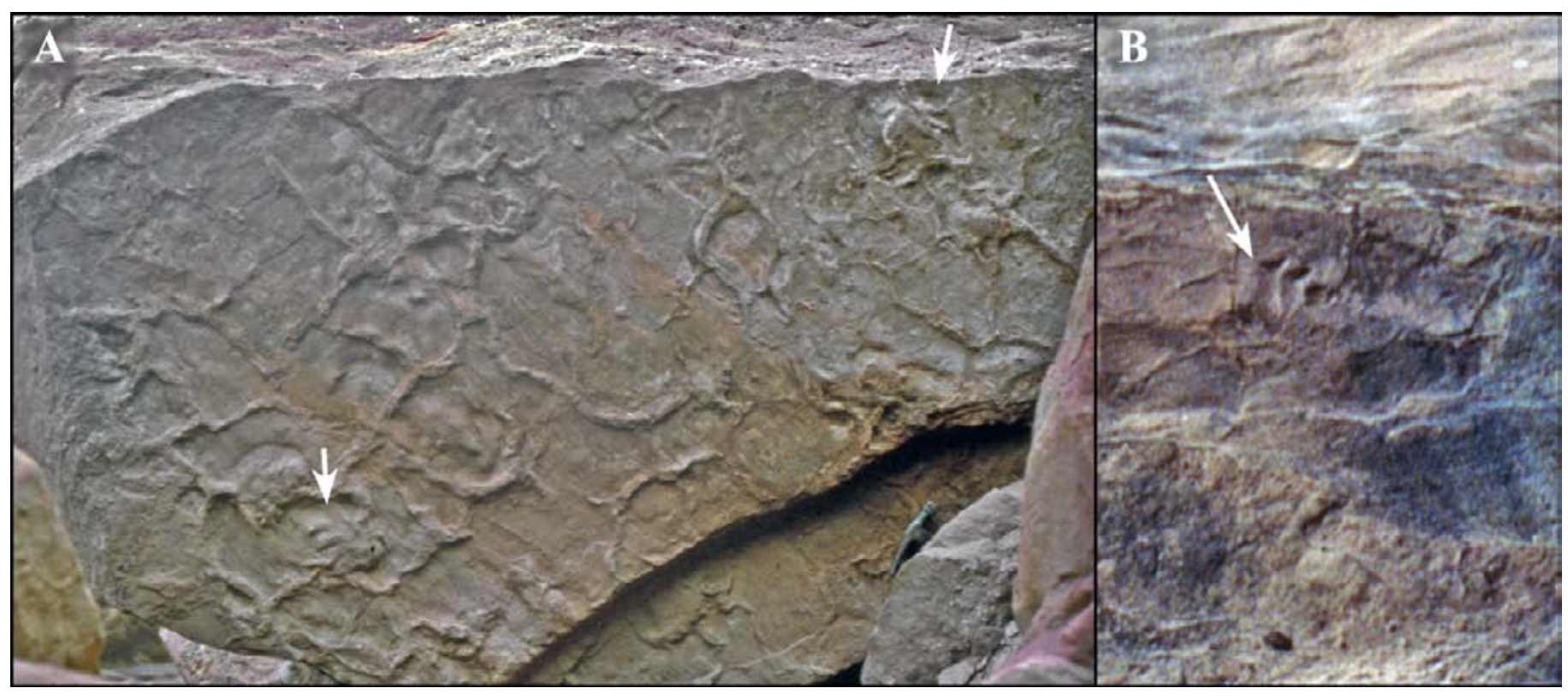

Figure 7. Natural casts of indeterminate tetrapod footprints (not collected) and mud cracks from the Honeycomb Point Formation. (A) Displaced block $\left(45.31579^{\circ} \mathrm{N}, 65.55524^{\circ} \mathrm{W}\right)$. (B) Undersurface of ledge high on exposure $\left(45.31196^{\circ} \mathrm{N}\right.$, $65.55958^{\circ} \mathrm{W}$ ). Arrows point to the most clearly visible footprints (modified from Olsen and Et-Touhami 2008).

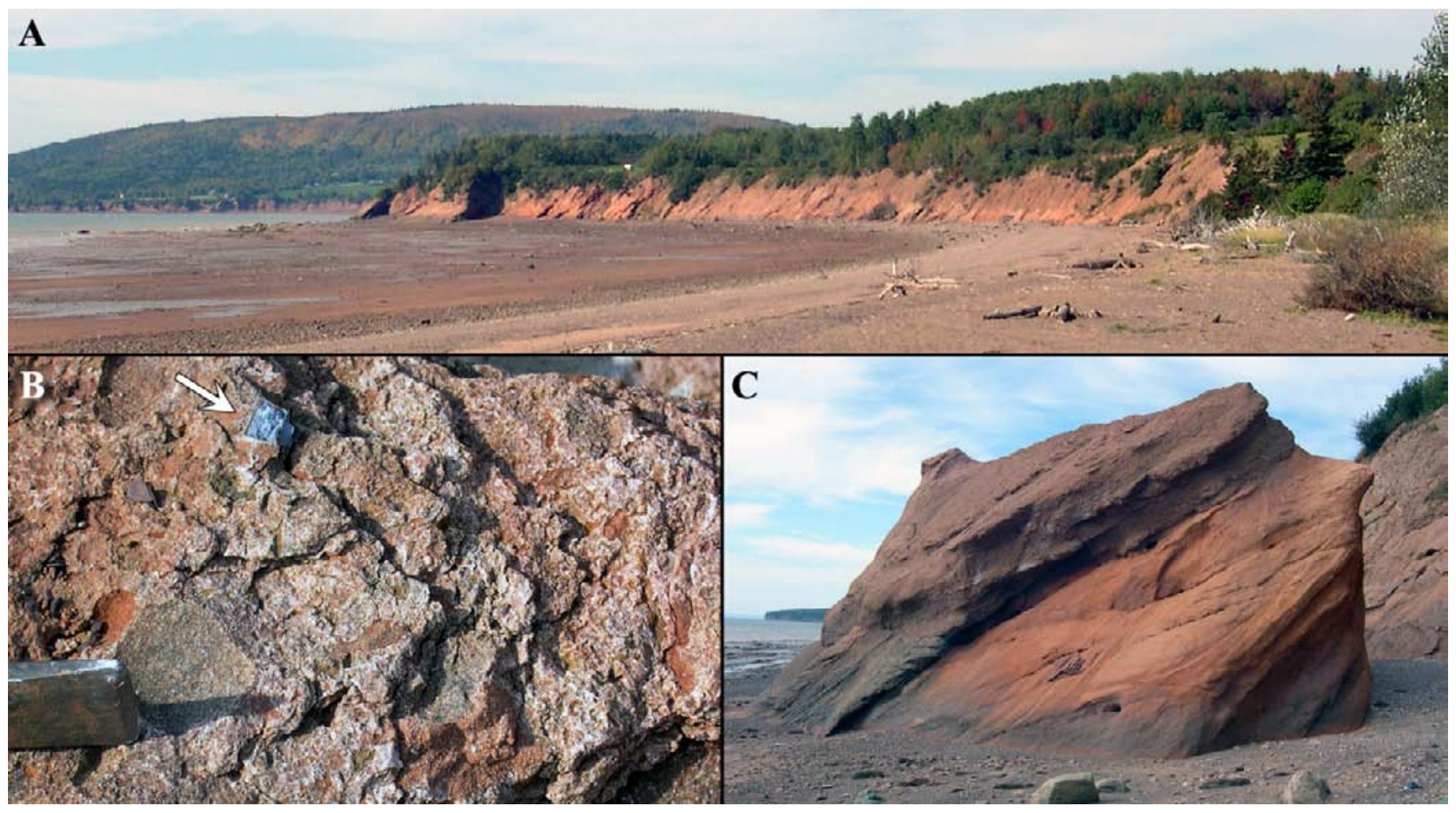

Figure 8. Outcrops of the Economy Member of the Wolfville Formation. (A) Overview of outcrops looking west from $45.394493^{\circ} \mathrm{N}, 63.948962^{\circ} \mathrm{W}$. (B) Typical example of bone fragment (arrow) in calcite-cemented clay-pebble conglomerate $\left(45.396105^{\circ} \mathrm{N}, 63.963333^{\circ} \mathrm{W}\right)$. (C) Interbed of aeolian sandstone, upper part of the Economy Member $\left(45.396002^{\circ} \mathrm{N}\right.$, $\left.63.960578^{\circ} \mathrm{W}\right)$. 


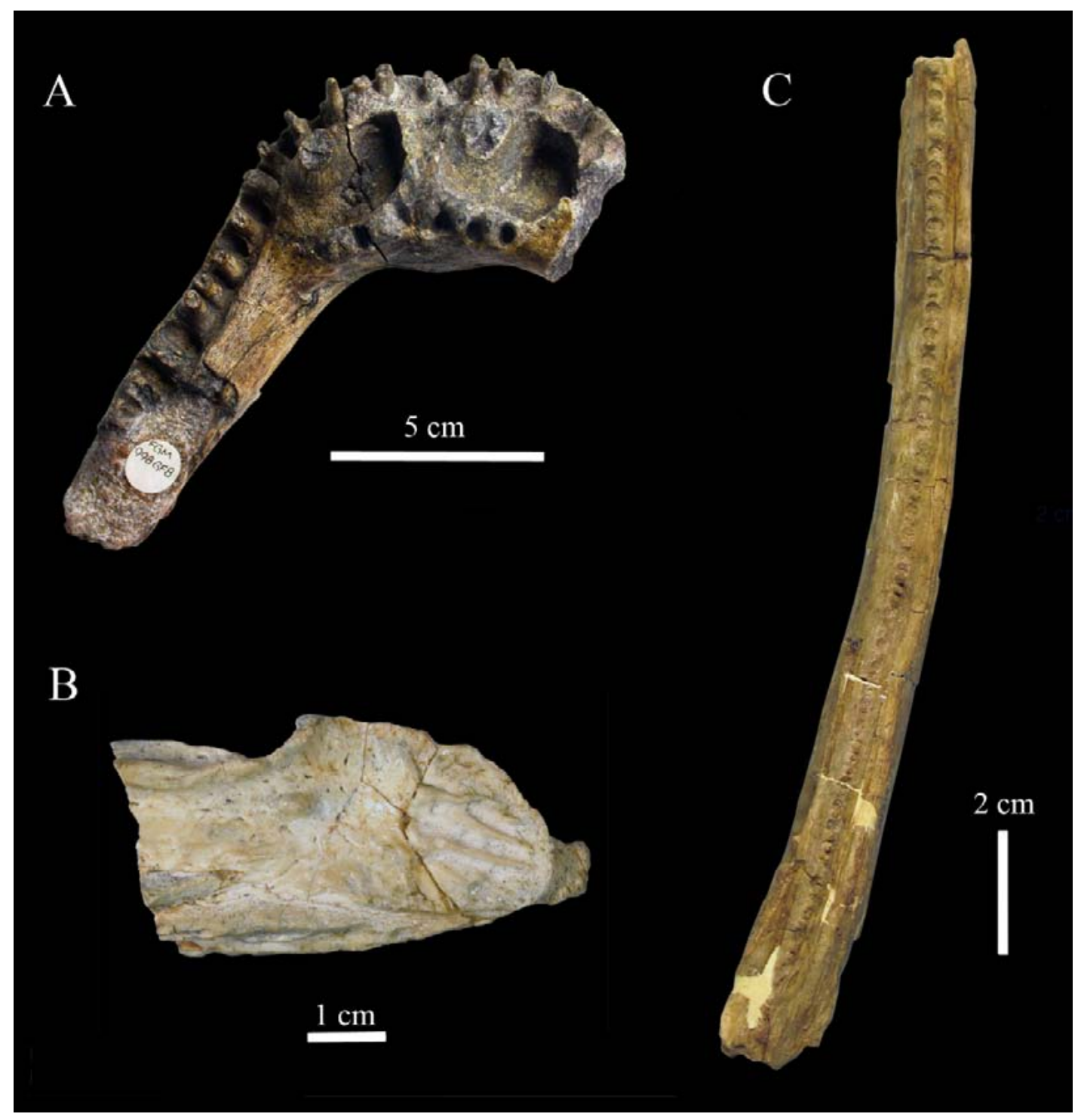

Figure 9. Mandibular remains of temnospondyl stem-amphibians from the Economy Member of the Wolfville Formation at Carrs Brook. (A) Partial mandible of capitosauroid (FGM998GF8) in occlusal view. Image courtesy of Tim Fedak. (B) Incomplete left mandibular ramus of lonchorhynchine trematosauroid (YPM VPPU 021691) in occlusal view. (C) Posterior portion of left mandibular ramus of capitosauroid (YPM VPPU 021692) in lateral view.

Welles (1993) as a left premaxilla (YPM VPPU 023686) is not clearly identifiable as such. The posterior region of a left mandibular ramus (YPM VPPU 021692) assigned to Cosgriffius by Welles (1993) belongs to a capitosauroid based on the long, transversely broad and concave postglenoid region, the shape of its posterior end, and the ornamentation on its lateral surface (Fig. 9C).

Complete or partial jaws with teeth, as well as a few other bones, document the presence of procolophonid parareptiles. The smallest dentaries hold a few simple conical teeth (e.g., NSM012GF032.007), whereas larger ones (e.g., FGM000GF86) have transversely broad, bicuspid teeth more posteriorly. It is not clear whether this difference indicates the presence of multiple taxa or merely different growth stages of a single form. Li (1983) documented ontogenetic change from conical, sometimes labiolingually compressed tooth crowns to transversely wide bicuspid crowns in the Early Triassic procolophonid Eumetabolodon brachycephalus from Inner Mongolia, China. The neural arch of a dorsal vertebra (YPM VPPU 023500; width across prezygapophyses: $40 \mathrm{~mm}$ ) probably belongs to a rather large procolophonid based on its 'swollen' configuration.

Archosauromorph reptiles are represented by at least four groups. An incomplete cervical vertebra (YPM VPPU 022000) represents the first record of a long-necked tanystropheid from North America (Fig. 10). It most 
closely resembles anterior to mid-cervical vertebrae of Tanystropheus spp. from the Anisian to Norian of Europe, the Anisian of the Middle East, and the Ladinian or Carnian of China (Wild 1973, 1980; Rieppel et al. 2010). The neural spine forms a low dorsal ridge, and the postzygapophyses extend posteriorly beyond the posterior end of the centrum. The vertebral centrum is distinctly elongated (length: 76 $\mathrm{mm}$, anterior height: c. $7 \mathrm{~mm}$ ), more so than in more basal tanystropheid taxa (Sennikov 2011), and we thus identify it as cf. Tanystropheus sp.

An isolated tooth crown (NSM012GF032.001) is labiolingually wide (c. $7 \mathrm{~mm}$ ) and has three distinct cusps (with worn or abraded apices) that are linked by low ridges. As preserved, the central cusp is the smallest and one of the outer cusps is larger than the other two cusps. The tooth is proportionally narrower transversely than teeth of the archosauromorph Trilophosaurus (Spielmann et al. 2008) and most closely resembles teeth of the enigmatic Tricuspisaurus thomasi from Late Triassic (Norian) fissure fillings in Wales. The latter taxon has variously been classified as a trilophosaurid (Robinson 1957) or a procolophonid (Fraser 1985).

A well-preserved left pubis with an attached fragment of the ilium (YPM VPPU 021806) has a distinct pubic 'apron' and most likely represents an archosauriform. A partial left mandibular ramus of a small reptile with nine preserved alveoli and teeth (NSM012GF032.002; preserved length: 32 $\mathrm{mm}$ ) is possibly referable to the Archosauriformes based on the distinctive ornamentation of fine ridges and grooves along the ventrolateral surface of the dentary. The dentary is long and low, and its medial surface is concealed by the splenial, which is separated from the dentary by a long, slender coronoid more posteriorly. A similarly long and splint-like coronoid is present in various archosauriform reptiles, but also in the crocodylomorph Sphenosuchus (Gower 2003). The small teeth have simple conical crowns and show thecodont implantation. There are two possibly pathological swellings on the dorsolateral margin of the jaw behind the tooth row and on the ventromedial edge further posteriorly, respectively.

Finally, tall, slender and apically recurved tooth crowns with serrated cutting edges (e.g., YPM VPPU 019909; 4 serrations per $\mathrm{mm}$ ) presumably have archosauriform affinities but cannot be assigned to a particular taxon.

Huber et al. (1993) established the Economian Land Vertebrate Faunachron based on the tetrapod remains from the Economy Member of the Wolfville Formation and considered it Anisian in age. The currently available tetrapod material from the Economy Member, however, is inadequate for a definitive biochronological assessment on its own. Huber et al. (1993) highlighted the presence of what they called cf. Cosgriffius sp. because Cosgriffius campi occurs in the Wupatki Member of the Moenkopi Formation in Arizona (Welles 1993), which has been dated as late

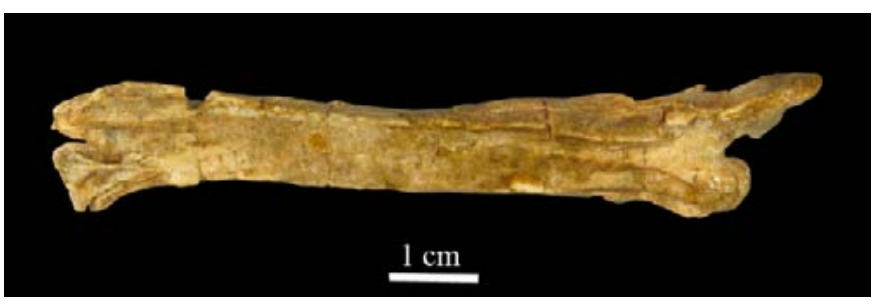

Figure 10. Left lateral view of incomplete cervical vertebra of cf. Tanystropheus sp. (YPM VPPU 022000) from the Economy Member of the Wolfville Formation at Carrs Brook.

Early Triassic (Olenekian) by Lucas and Schoch (2002). Previously reported lonchorhynchine trematosaurids all date from the Early and early Middle Triassic, but two clades of Trematosauridae are now known to range into the Late Triassic (Schoch and Milner 2000; Sues and Schoch 2013). Thus, it is conceivable that the lonchorhynchine from the Economy Member, which is not definitely referable to Cosgriffius, is geologically younger. Tanystropheus has a reported stratigraphic range extending from the late Anisian to the late Norian in Europe (Wild 1980). None of the identifiable tetrapod taxa from the Economy Member has been recorded from the overlying Evangeline Member of the Wolfville Formation, which has yielded at least one taxon (Metoposaurus bakeri) indicating a Carnian age (see below).

Whereas all the identifiable tetrapod taxa from the Economy Member have long ranges that are not diagnostic at the level of age (stage) or even epoch, a sequence of members comparable to that of the Wolfville Formation occurs in the Timezgadiouine Formation of the Argana Basin in the western High Atlas of Morocco, which was deposited at a tropical palaeolatitude similar to that of the Wolfville Formation (Olsen and Et-Touhami 2008). There, the lower part of the Timezgadiouine Formation, the Aglegal Member, has yielded capitosauroids but lacks metoposaurs and is succeeded by the Irohalene Member with abundant metoposaurs and no capitosauroids (Jalil 1999). The Aglegal Member has also yielded unambiguous examples of the pseudosuchian ichnotaxon Chirotherium barthii, which is restricted to Middle Triassic strata elsewhere (Klein et al. 2011). This suggests that the partitioning of the temnospondyl assemblages into an older capitosauroidtrematosaurid and a younger metoposaurid assemblage has temporal significance within the Pangaean tropics, corresponding in a broad way to the similar partitioning of the Early to Middle Triassic temnospondyl assemblages from the Moenkopi Formation and the Late Triassic ones from the Chinle Formation, which were also deposited at tropical palaeolatitudes. However, no such temporal partitioning is evident in the higher-latitude Germanic Basin tetrapod 
assemblages where capitosauroids have a range apparently spanning the entire Triassic Period (Schoch and Milner 2000; Schoch 2011).

\section{Evangeline Member}

The upper part of TS II is made up of the Evangeline Member, the type section of which consists of the coastal outcrops at Evangeline Beach, Kings County (defined in Appendix; Fig. 4E-F). Skeletal remains of tetrapods are quite common in this member, not only as dissociated bones and skulls in the calcite-cemented, pebbly intraformational conglomerate beds as in the Economy Member (found along with unionoid clams) but also as bones and skeletons in the better-sorted sandstones and mudstones. The most important sections for tetrapod fossils in the Evangeline Member are the type section, Burntcoat Head (Burntcoat, Hants County) and near the community of Noel Shore (Hants County) (Fig. 11). Other less productive sites for skeletal remains include Boot Island (Kings County) and Longspell Point (Kingsport, Kings County).

William Take first discovered tetrapod bones in the

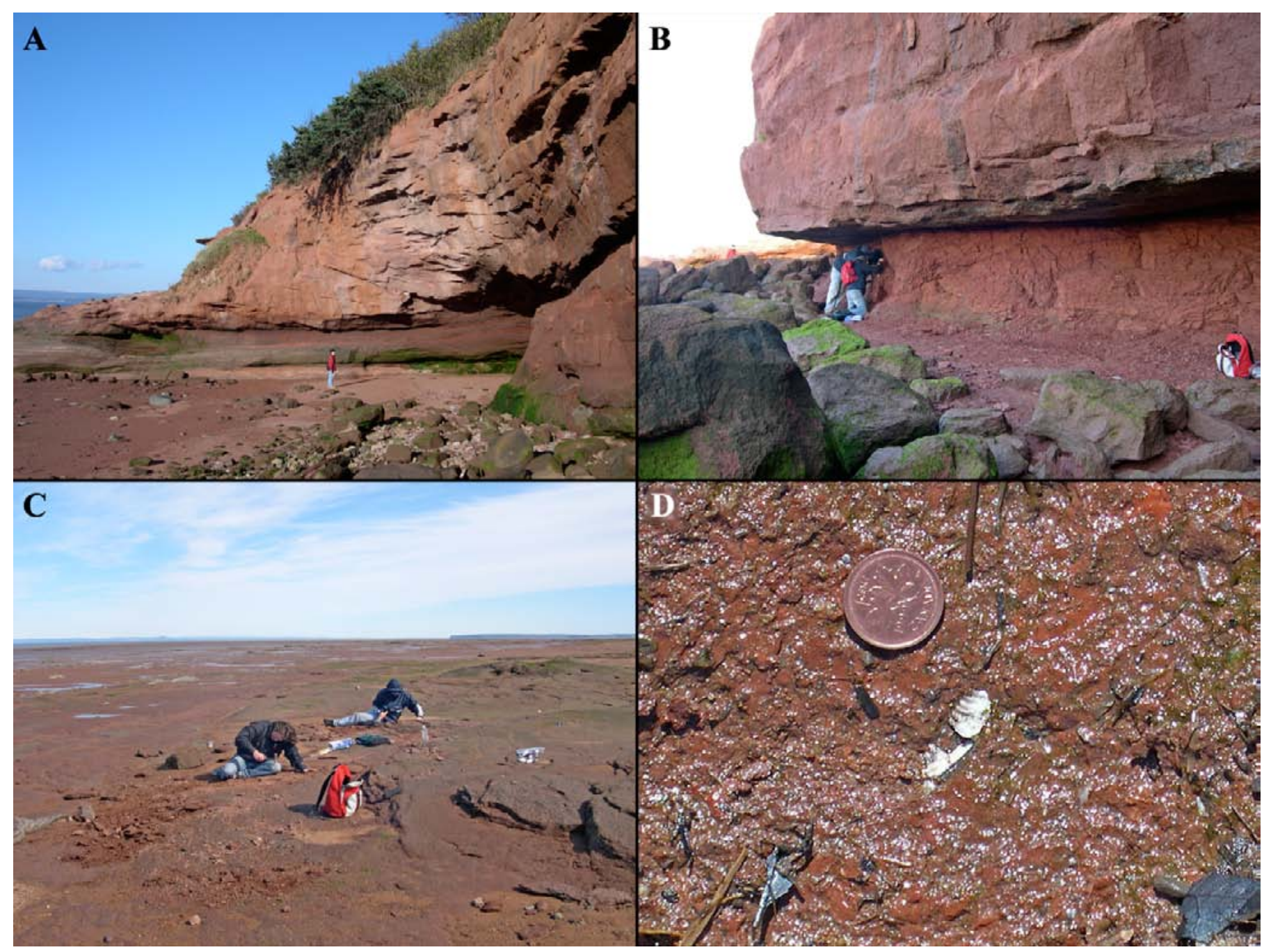

Figure 11. Outcrops of the Evangeline Member of the Wolfville Formation. (A) Burntcoat Head, outcrop of large-scale trough-cross-bedded pebbly sandstone overlying heavily bioturbated muddy sandstone $\left(45.312325^{\circ} \mathrm{N}, 63.805091^{\circ} \mathrm{W}\right)$. Jun Liu (Chinese Academy of Sciences) for scale. (B) Bone-bearing mudstone beneath sandstone, east of Burntcoat Head, East Hants, Hants County, Nova Scotia $\left(45.312971^{\circ} \mathrm{N}, 63.804149^{\circ} \mathrm{W}\right)$; Sterling Nesbitt (Virginia Tech) and Alan Turner (Stony Brook University) for scale. (C) Foreshore outcrops, Evangeline Beach, Grand Pré, Kings County, Nova Scotia $\left(45.138384^{\circ} \mathrm{N}\right.$, $64.323265^{\circ} \mathrm{W}$ ), view looking north; Sterling Nesbitt and Alan Turner for scale. The locality yielded a partial rhynchosaur maxilla and fragmentary postcranial remains of an unidentified small archosaur. (D) Fragment of rhynchosaur dentary embedded in calcite-cemented clay pebble conglomerate; same locality as (C). Canadian one-cent coin is $19.05 \mathrm{~mm}$ in diameter. 
Evangeline Member and brought them to the attention of Donald Baird in November 1958. At first in collaboration with Take (Baird and Take 1959), Baird undertook subsequent palaeontological reconnaissance of the strata of this unit. After 1985 the present authors and others have continued this work.

Although scraps of bone are not uncommon, the dissociated and fragmentary nature of most skeletal remains often renders their anatomical and taxonomic identification difficult, and sometimes impossible. It was only through persistent collecting over more than four decades that sufficient material has been gathered to permit a new scientific evaluation of the tetrapod assemblage from the Evangeline Member. Very rarely, partial tetrapod skeletons and associated but disarticulated bones of tetrapods occur both in sandstones and mudstones. We offer here what is perhaps a conservative assessment of the tetrapod biodiversity in the Evangeline Member, based only on specimens that show derived features diagnostic for particular clades.

To date, temnospondyls are represented only by the metoposaurid Metoposaurus bakeri (originally assigned to "Buettneria" by Case 1931). It occurs as a natural mould of much of a skull roof from Noel Head (YPM VPPU 021742; Baird 1986; Hunt 1993) (Fig. 12). As in specimens of Metoposaurus bakeri from Texas, the elongate lacrimal is excluded from the anterior margin of the orbit by the contact between the prefrontal and jugal (Hunt 1993; Sulej 2007). YPM VPPU 021742 represents an immature specimen based on its small size (length of skull roof along the midline c. $190 \mathrm{~mm}$ ), as well as the relative proportions and pattern of sculpturing of the skull roof, especially in the postorbital region. In addition to this skull roof, the mould of a clavicle with characteristic external sculpturing and isolated vertebral centra provide evidence for the presence of metoposaurid temnospondyls in the Evangeline Member. Metoposaurids have long, dorsoventrally strongly flattened skulls and small orbits that are placed far forward on the cranium. These animals were obligatory aquatic predators. Despite reviews by Hunt (1993) and Sulej (2007), a rigorous phylogenetic assessment of metoposaurid diversity is still needed. For example, Baird (1986), Hunt (1993) and Schoch and Milner (2000) assigned the species bakeri to Metoposaurus, whereas Sulej (2007) still followed Case (1931) in retaining this taxon in "Buettneria" (a preoccupied generic name now replaced by Koskinonodon; Mueller 2007).

By far the most common tetrapod fossils in strata of the Evangeline Member are tooth-bearing jaws of procolophonid parareptiles (Fig. 13). Sues and Baird (1998) formally named and described three taxa diagnosed by their respective dentitions: Acadiella psalidodon, Haligonia bolodon, and Scoloparia glyphanodon. They also re-identified a skull and associated postcranial bones (NSM996GF82.1), earlier referred by Baird and Olsen (1983) to Leptopleuron, which is otherwise known only from the Lossiemouth Sandstone Formation (Late Triassic) of Scotland (Säilä 2010), as an immature specimen of Scoloparia glyphanodon.

Scoloparia glyphanodon is by far the most common procolophonid in the Evangeline Member (Fig. 13A). In addition to numerous jaw elements, it is known from several skulls. The more posterior maxillary and dentary teeth of Scoloparia have transversely aligned, chisel-like tooth crowns that bear three cusps when unworn rather than only two as in most procolophonids. The quadratojugal bears a cluster of long, slender, posterolaterally projecting bony spines. The holotype of Scoloparia glyphanodon (NSM996GF83.1) has a 'nuchal shield' composed of small, polygonal osteoderms, but no other known specimen preserves this distinctive feature (Sues and Baird 1998). Phylogenetic analysis places Scoloparia as a member of Leptopleuroninae, the most derived clade of Procolophonidae, which also includes the Late Triassic (Norian-Rhaetian) Hypsognathus fenneri from eastern North America (Sues et al. 2000). Cisneros (2008) placed Scoloparia glyphanodon as the sister-taxon of the Early to early Middle Triassic Sclerosaurus armatus from the Buntsandstein of Germany and Switzerland based solely on the shared presence of dermal armour. However, this coding ignores the profound differences in the structure of the dermal armour in the two taxa. Unlike Scoloparia, Sclerosaurus has two or three rows of sculptured osteoderms on either side of the midline of the body and lacks a 'nuchal shield' (Sues and Reisz 2008).

The holotype of Acadiella psalidodon comprises an associated right maxilla and partial mandibular ramus as well as part of the pterygoid flange (NSM996GF69.1; Fig. 13B). Its posterior maxillary and dentary teeth have anteroposteriorly rather than transversely aligned crowns with serrated apical ridges (Sues and Baird 1998). Haligonia bolodon, known only from a right maxilla (NSM996GF74.1, holotype) and a left dentary (NSM996GF31.1), has upper and lower tooth rows that have four small teeth followed by a greatly enlarged tooth with a bulbous crown at the back of the jaw. As yet too little is known about the cranial structure of Acadiella psalidodon and Haligonia bolodon to assess their respective phylogenetic positions. Procolophonid parareptiles are superficially lizard-like forms usually less than $50 \mathrm{~cm}$ long. Their structure of their dentition suggests herbivorous or omnivorous habits.

Archosauromorph reptiles are represented in the Evangeline Member by a rhynchosaur, a trilophosaur, diverse pseudosuchians, and a possible ornithodiran (Figs. 14-16).

Baird (in Carroll et al. 1972) reported the presence of two taxa referable to a group of probably herbivorous archosauromorph reptiles, Trilophosauridae. These identifications were based on fragmentary cranial remains and thus are problematical. One of these specimens, a natural mould of a small dentary, is referable to 


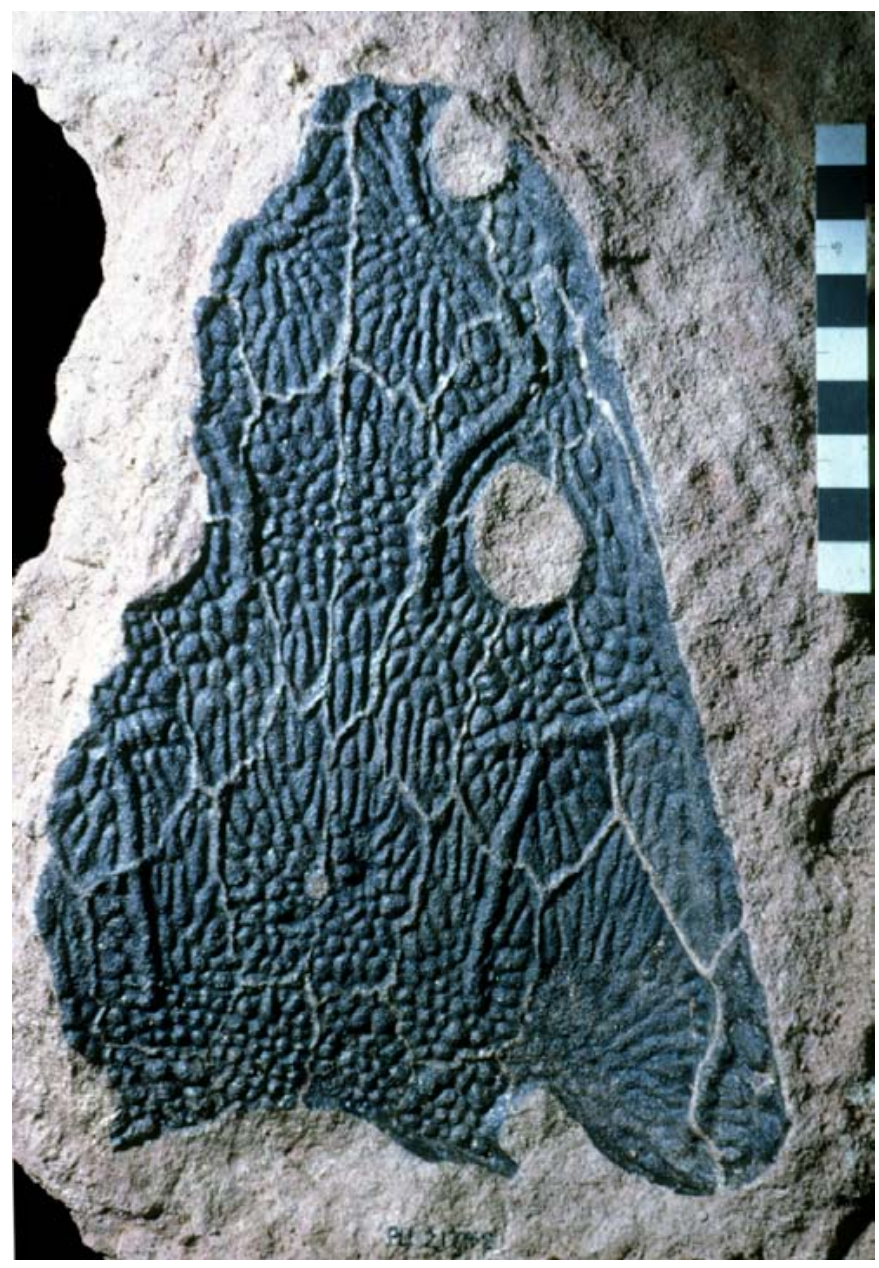

Figure 12. Natural mould of the dorsal surface of a skull roof of Metoposaurus bakeri (YPM VPPU 021742) from the Evangeline Beach Member at Noel Head.

Teraterpeton hrynewichorum, which Sues (2003) named on the basis of an excellently preserved, nearly complete skull and much of the postcranial skeleton collected from Burntcoat Head by the avocational collectors George and Sandy Hrynewich (NSM994GF041; Fig. 14A). As in the Late Triassic Trilophosaurus spp. from the American Southwest (Spielmann et al. 2008), the skull of Teraterpeton hrynewichorum has only large upper temporal fenestrae and an otherwise solid, deep temporal region. Unlike in Trilophosaurus spp., the edentulous premaxillae and symphyseal portions of the dentaries are elongate. The external naris is distinctly longer than the orbit. Both the maxilla and palatine bear teeth whose crowns have bulbous bases, a single tall cusp, and an anterior (mesial) 'heel' whereas the dentary teeth have the reverse configuration with a tall cusp and a posterior (distal) 'heel'. Phylogenetic analysis indicated that Teraterpeton hrynewichorum is most closely related to Trilophosaurus spp. among known

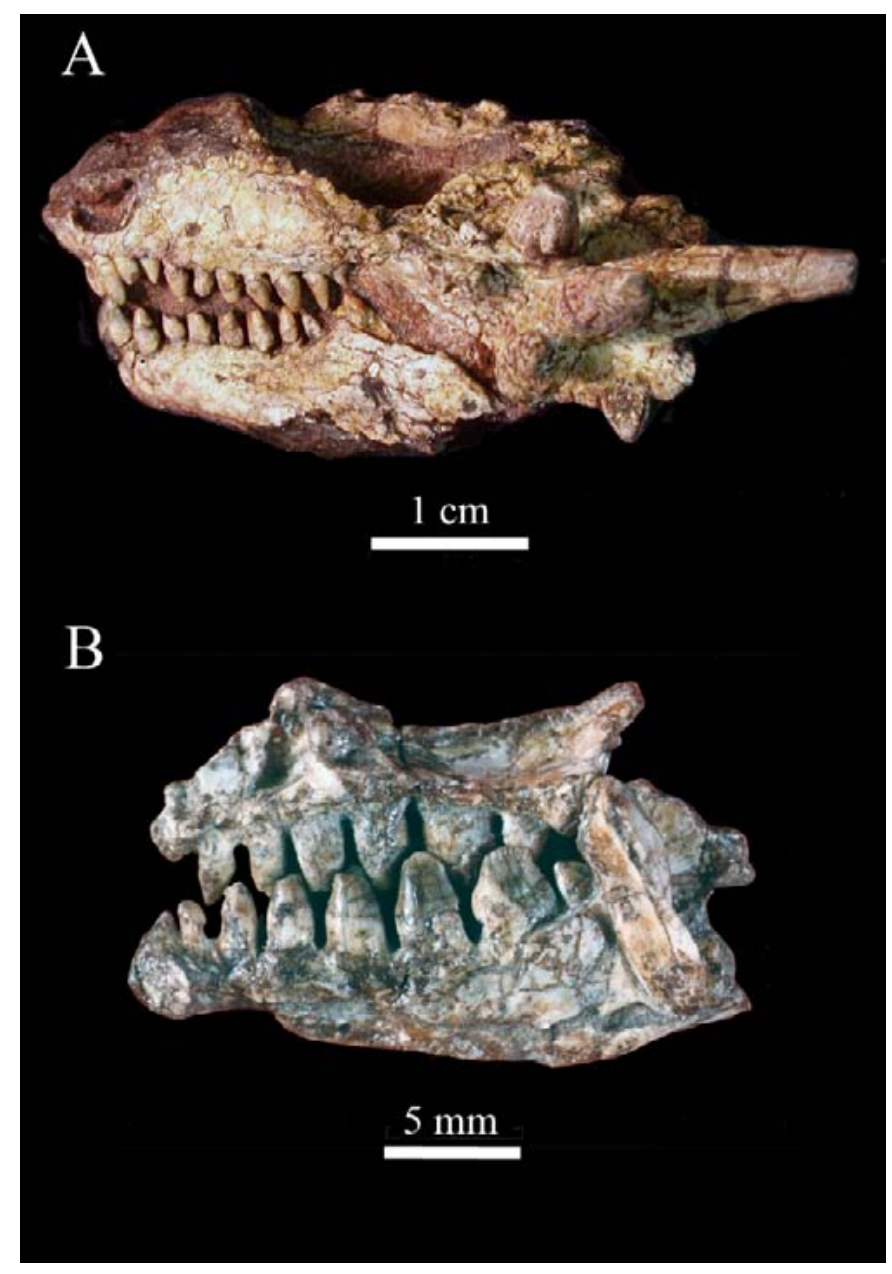

Figure 13. Procolophonid parareptiles from the Evangeline Beach Member. (A) Scoloparia glyphanodon, partial skull (ROM 47484) in left lateral view. (B) Acadiella psalidodon (NSM996GF69.1, holotype), medial view of right upper and lower jaws in occlusion.

archosauromorph taxa (Sues 2003). Like rhynchosaurs, Teraterpeton was presumably herbivorous. The distinctive structure of its jaw joint and its maxillary and palatine teeth indicate fore-and-aft jaw motion of the mandible. The deep, blade-like ungual phalanges and robust pectoral girdle suggest that Teraterpeton hrynewichorum was a burrower (which may well account for the excellent, articulated preservation of the holotype).

Jaw elements of various sizes (Fig. 14B-C), incomplete fused parietals (NSM012GF032.023), and the excellently preserved basicranial portion of a braincase (NSM012GF032.022; Fig. 14D) document the presence of a hyperodapedontine rhynchosaur in the Evangeline Member (Baird 1963). Skeletal remains of this taxon have most frequently been found at Evangeline Beach. As in other rhynchosaurs, the premaxilla (NSM012GF032.024) 


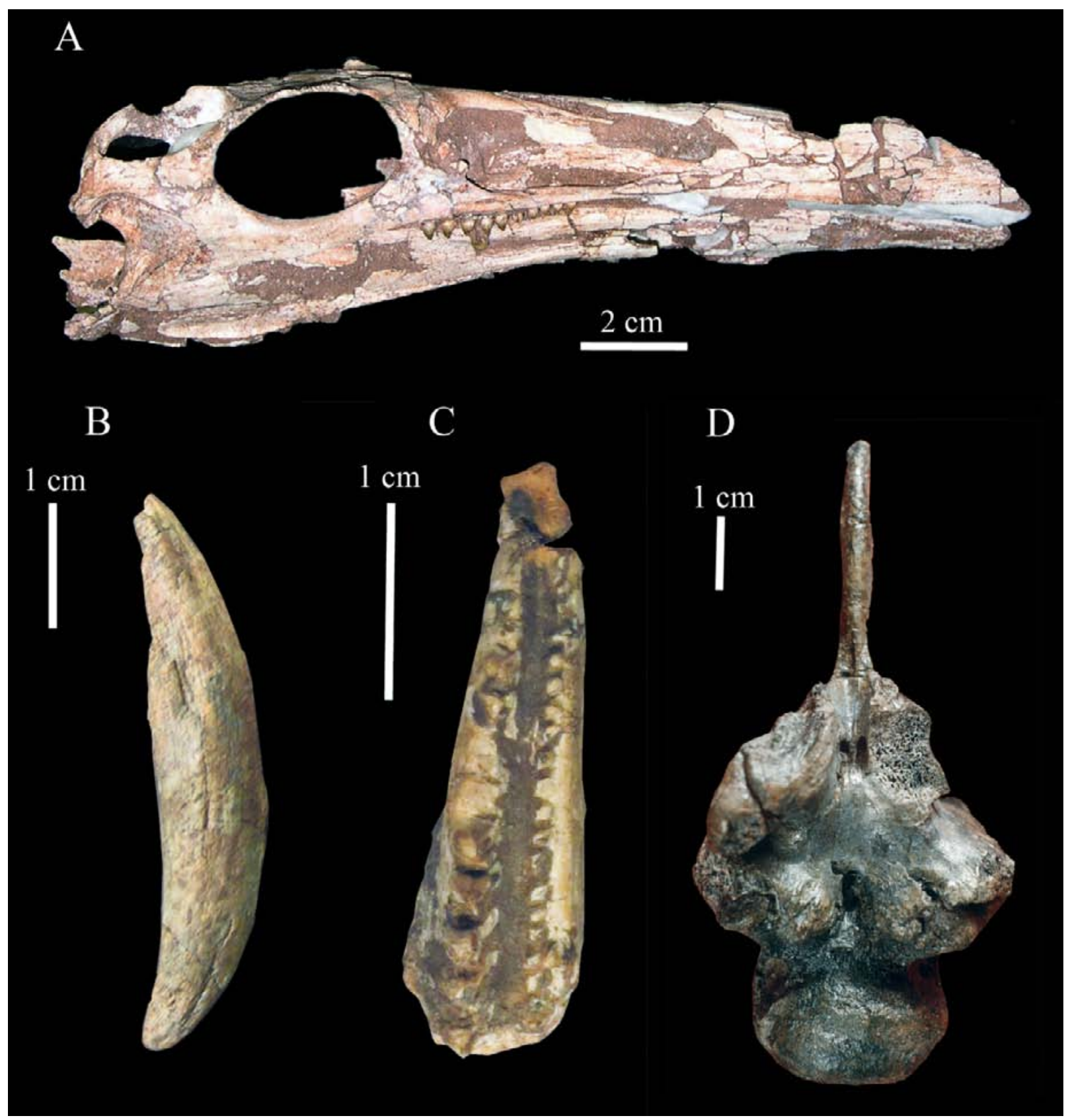

Figure 14. Archosauromorph reptiles from the Evangeline Member of the Wolfville Formation. (A) Skull of Teraterpeton hrynewichorum (NSM994GF041, holotype) from Burntcoat Head in right lateral view. (B) Right premaxilla of a hyperodapedontine rhynchosaur (NSM012GF032.024) from Evangeline Beach east in lateral view. (C) Right maxilla of a juvenile hyperodapedontine (NSM012GF032.026) from Burntcoat in occlusal view. (D) Basioccipital-parabasisphenoid complex of a hyperodapedontine (NSM012GF032.022) from Evangeline Beach in ventral view.

is downturned (relative to the maxilla) and forms an edentulous 'beak' (Fig. 14B). The maxilla has only a single deep longitudinal occlusal groove separating the lateral and medial rows of teeth (1 or 2 each) (Fig. 14C). The lateral teeth are pyramidal. Baird (in Carroll et al. 1972) compared the material to the Hyperodapedon gordoni from the Lossiemouth Sandstone Formation of Scotland. Later authors (e.g., Lucas et al. 2002) referred the Wolfville material to the genus Hyperodapedon without further discussion. The rhynchosaur from the Evangeline Member is distinguished from most other hyperodapedontines by the absence of lingual teeth on the dentary. During the 


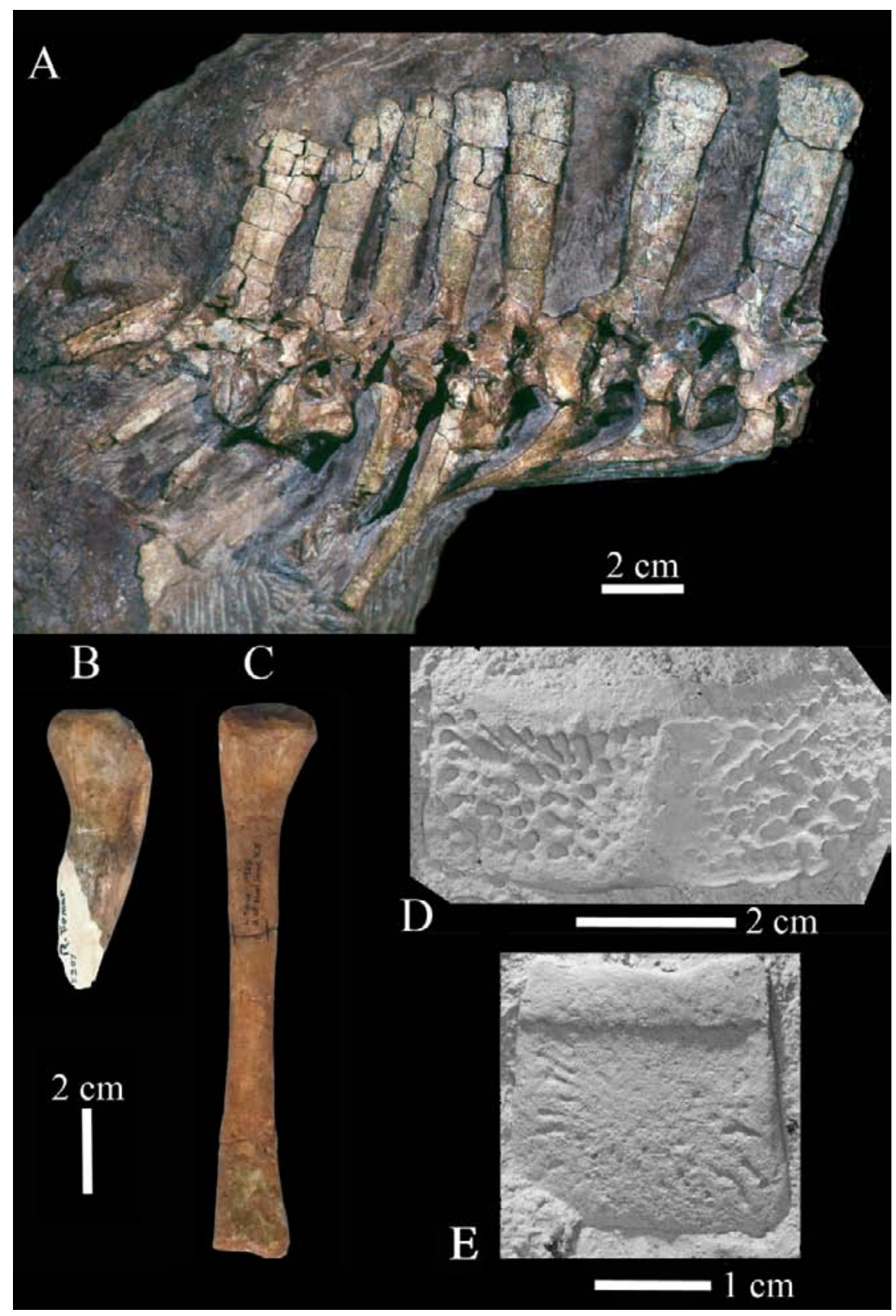

Figure 15. Pseudosuchian archosaurs from the Evangeline Member of the Wolfville Formation. (A) Posterior cervical and anterior dorsal vertebrae with associated ribs of a paracrocodylomorph (NSM998GF46.1) in right lateral view. (B) Proximal end of the right femur of an aetosaur (NSM012GF032.14) in posterior view. (C) Left tibia of a paracrocodylomorph (NSM012GF032.015) in posterior view. (D) Cast of a paramedian dorsal osteoderm of an aetosaurine aetosaur (NSM012GF032.033) in dorsal view. (E) Cast of a ventral osteoderm of an aetosaur (NSM012GF032.032).

Triassic, rhynchosaurs were a widely distributed group of presumably herbivorous archosauromorph reptiles. The maxillae typically bear multiple rows of teeth on either side of a longitudinal groove; some derived taxa have additional grooves between the tooth rows.
Archosaurian reptiles from the Evangeline Member comprise various taxa of crocodile-line archosaurs (Pseudosuchia) (Figs. 15, 16A-B) and a possible representative of bird-line archosaurs (Ornithodira) (Fig. 16C). Several isolated osteoderms with a raised anterior 


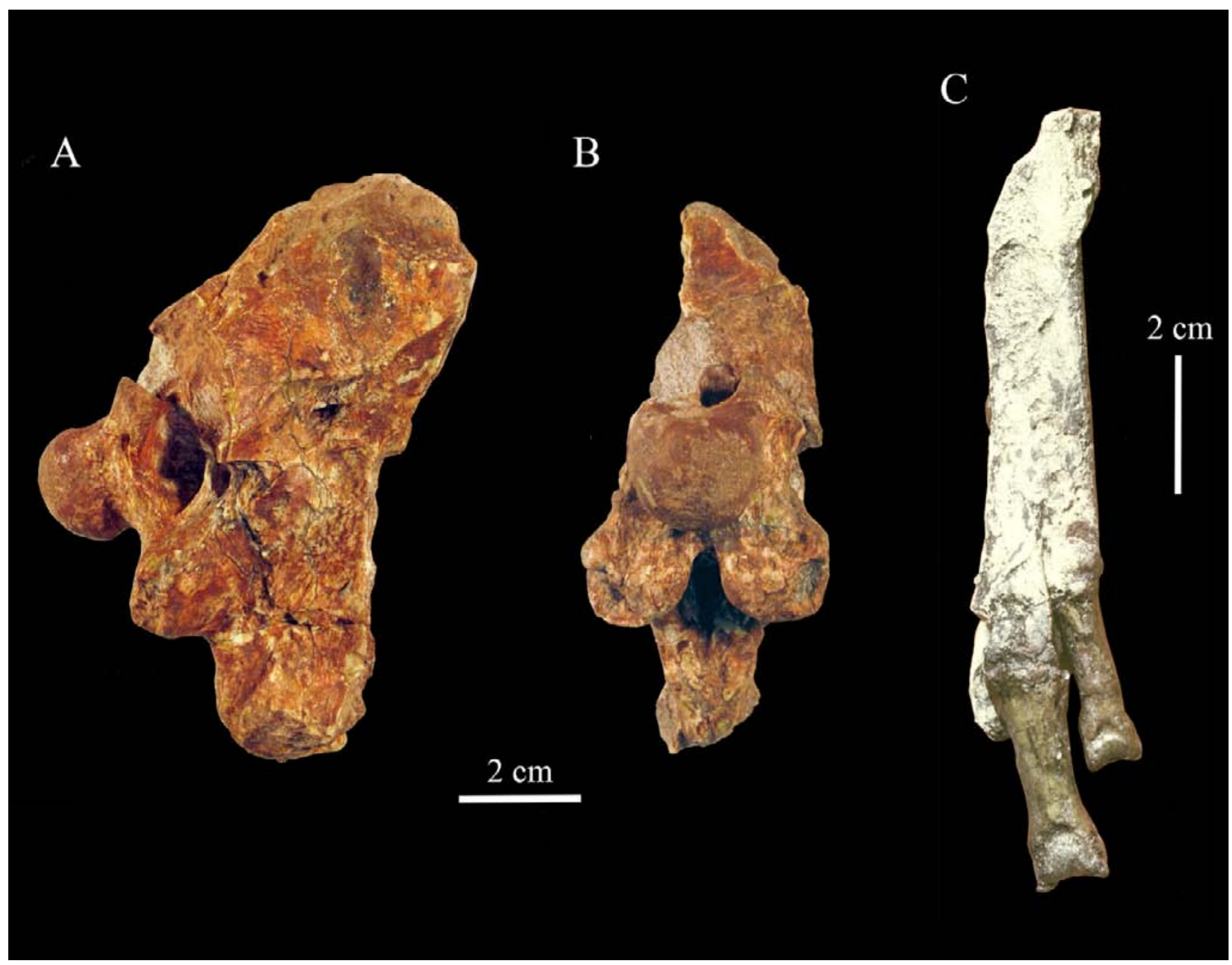

Figure 16. Pseudosuchian and ornithodiran archosaurs from the Evangeline Member of the Wolfville Formation. (A-B) Partial braincase of a paracrocodylomorph (YPM VPPU 020750) in (A) right lateral and (B) occipital views. (C) Right metatarsals II-IV (mostly as plaster cast made from natural mould) and associated proximal phalanges (YPM VPPU 021694) of a possible ornithodiran in dorsal view.

'bar' and radiating ornamentation are typical of Aetosauria, a group of heavily armoured, omnivorous or herbivorous pseudosuchians from the Late Triassic. A paramedian dorsal osteoderm of an aetosaurine (NSM012GF032.033; Fig. 15D; greatest width: $59 \mathrm{~mm}$ ) shows distinct flexure along the midline and well-developed sculpturing composed of closely spaced pits, the more anterior ones of which are elongate and extend anterolaterally. A ventral osteoderm (NSM012GF032.032; Fig. 15E; greatest width: $24 \mathrm{~mm}$ ) has relatively weak, sparse pitting and resembles those of Coahomasuchus kahleorum from the Dockum Group (Late Triassic) of Texas (William Parker, personal communication). The well-preserved proximal portion of a right femur (NSM012GF032.014; Fig. 15B) is referable to aetosaurs based on the large posteromedial tuber on the proximal end and the structure of the fourth trochanter (Nesbitt 2011). Scattered postcranial remains recovered from a mudstone horizon at Burntcoat probably belong to a small aetosaur. The rectangular osteoderms bear sculpturing composed of minute pits.

Mostly incomplete and dissociated skeletal elements document the presence of paracrocodylomorph pseudosuchians (Figs. 15, 16A-B). A set of articulated posterior cervical and anterior dorsal vertebrae with associated ribs (NSM998GF46.1; Fig. 15A) probably belongs to a paracrocodylomorph. The vertebrae have tall neural spines. A left tibia (NSM012GF032.015; Fig. $15 \mathrm{C}$; length: $131 \mathrm{~mm}$ ) has a straight shaft and is gently 
concave posteriorly at its distal articular end. It is probably referable to a paracrocodylomorph. A well-preserved partial braincase (YPM VPPU 020750; Fig. 16A-B) closely resembles that of Postosuchus kirkpatricki from Late Triassic strata in the American Southwest (Weinbaum 2011, fig. 24), especially in the structure of the parabasisphenoid, which is greatly elongated between the basal tubera and has a deep, dorsoventrally extended median recess. However, the parabasisphenoid is less extended vertically, and the prootic has separate foramina for branches $\mathrm{V}^{1}$ and $\mathrm{V}^{2-3}$ of the trigeminal nerve (Fig. 16A).

Surprisingly, the Evangeline Member has not yielded any diagnostic remains of phytosaurs to date. These superficially crocodile-like amphibious predators are very common in other Late Triassic deposits in Europe, Morocco, and North America and are typically found in association with the perennially aquatic metoposaurs. Phytosaurs were long considered early crocodile-line archosaurs but Nesbitt (2011) recently placed them outside crown-group Archosauria.

In contrast to crocodile-line archosaurs, bird-like archosaurs (Ornithodira) are very rare in the Evangeline Member. Baird (in Carroll et al. 1972) reported the presence of dinosaurs in this unit. He identified recurved, labiolingually flattened tooth crowns with finely serrated mesial and distal cutting edges as representing three size classes of theropod dinosaurs. The largest tooth crown in our sample has a mesiodistal diameter of $23 \mathrm{~mm}$ near the base and carinae with 5 serrations per millimetre. There are no features to suggest that any of these teeth are dinosaurian or even ornithodiran, and at least some of them more likely belong to paracrocodylomorph pseudosuchians.

Baird (in Carroll et al. 1972) reported a partial left maxilla containing a single tooth (NSM004GF012.001) as representing a tiny ornithischian dinosaur. Irmis et al. (2007, fig. 5B-D) published drawings of the jaw fragment (made by PEO) and showed that it lacks any features exclusive to ornithischians. Instead they noted similarities to Revueltosaurus callenderi, which was initially known only from isolated teeth from the Bull Canyon Formation (Late Triassic: Norian) of New Mexico that were considered ornithischian in origin. Recent finds of extensive skeletal remains of Revueltosaurus callenderi from the Chinle Formation (Late Triassic: Norian) of Arizona have now established that this taxon is a pseudosuchian closely related to aetosaurs, not an ornithischian dinosaur (Parker et al. 2005; Nesbitt 2011). A well-preserved left ilium lacking only the postacetabular process (NSM012GF032.021) from Evangeline Beach closely resembles those of aetosaurs but is also similar to that of Revueltosaurus (Parker et al. 2005, fig. $3 c$ ) in its possession of a short anterior (preacetabular) process.

To date the only possibly ornithodiran discovery from the Evangeline Member is a specimen comprising an articulated set of incomplete right metatarsals II-IV, each associated with the proximal phalanx of its respective pedal digit (YPM VPPU 021694); this specimen is preserved in part as bone and in part as natural mould that was filled in with plaster to document its former structure (Fig. 16C). On the associated label Baird identified this find as belonging to a small theropod dinosaur. However, there are no diagnostic features to indicate dinosaurian affinities. The metatarsals are long, slender, and appressed for their entire preserved lengths. Although some early crocodylomorphs also have such 'bundling' of the metatarsals these elements are generally not appressed for their entire length (Nesbitt 2011), and thus YPM VPPU 021694 more likely represents an ornithodiran.

Non-mammalian synapsids (therapsids) are represented only by the large traversodontid cynodont Arctotraversodon plemmyridon (Hopson 1984; Sues et al. 1992) and the as-yet-undescribed pelvic bones of a large dicynodont (Tim Fedak, personal communication). Arctotraversodon plemmyridon is known from three partial dentaries and three isolated teeth. The holotype of this taxon (YPM VPPU 019190; Fig. 17) is an incomplete right dentary (with an attached fragment of the left one) from the northeast corner of the Burntcoat headland. Arctotraversodon is readily distinguished by procumbent incisors with coarsely serrated mesial and distal cutting edges (Fig. 17A) and the presence of an enlarged mental foramen on the buccal surface of the dentary (Fig. 17B). Referred molariform postcanine teeth have mesiodistally short tooth crowns (Sues et al. 1992). An isolated lower postcanine (NSM983GF2.1) has three rather than two anterior cusps, a derived feature shared with Boreogomphodon jeffersoni from Late Triassic (Carnian) strata in Virginia and North Carolina, which also shares the presence of an enlarged mental foramen on the buccal surface of the dentary (Sues and Hopson 2010). Baird and Olsen's (1983) report of a dicynodont therapsid was based on the partial braincase (YPM VPPU 020750) reidentified here as that of a paracrocodylomorph pseudosuchian. However, Tim Fedak (personal communication) has found the ilia and sacrum of a large dicynodont, but this material has not yet been fully prepared and studied.

With the exception of Metoposaurus bakeri, all tetrapod remains from the Evangeline Member that are identifiable at lower taxonomic levels to date appear to be restricted to this unit and thus have no biostratigraphic utility. Metoposaurus bakeri itself is a faunal element of the Otischalkian, the oldest of the Late Triassic Land Vertebrate Faunachrons defined by Lucas (1998) in the American Southwest, and the only taxon that may be Carnian rather than Norian in age. Kozur and Weems (2010) reported the presence of a monospecific conchostracan assemblage with Euestheria minuta from Evangeline Beach (based on material collected by PEO). They argued that this species is restricted to what they considered early Carnian (Cordevolian) strata in the more southeastern 
basins of the Newark Supergroup. Presumably this is the same taxon that Powers (1916) reported as Estheria ovata from the Evangeline Member of Long Island (Evangeline Beach; Baird in Carroll et al. 1972) and Boot Island. Based on these faunal elements alone, a more precise dating than late Middle to early Late Triassic is not possible. However, the position of the Evangeline Member assemblage in the lower part of the basin section, well below strata dated as Norian based on magnetostratigraphy (see below), and below the position of the boundary between TS II and TS III, suggests a Carnian age.

Whiteside et al. (2011) argued that the procolophoniddominated Late Triassic tetrapod assemblages from the Newark Supergroup existed under semi-arid climatic conditions, whereas more or less coeval communities dominated by traversodontid cynodonts from Virginia and North Carolina appear to have been restricted to a narrow equatorial zone with more humid conditions. The tetrapod assemblage from the Evangeline Member clearly falls into the former category, with procolophonids representing most of the identifiable fossils. The traversodontid cynodont Arctotraversodon plemmyridon is only known from a few specimens, unlike its close relative Boreogomphodon jeffersoni, which tends to be common where present. Whereas the presence of relatively large, thick-shelled unionoid clams argues for perennial river settings, the presence of abundant palaeosol rhizoliths suggests at least seasonally dry conditions. The relative scarcity of metoposaurs and apparent absence of phytosaurs are consistent with the latter interpretation.

The stratigraphically highest outcrops of the Evangeline Member that have yielded bone are at Longspell Point near Kingsport, Kings County (e.g., Baird MS, p. 253); this occurrence is in calcite-cemented, pebbly intraformational conglomerate, similar in lithology to those outcrops elsewhere in the Evangeline Member that have produced bone. However, at Longspell Point the rest of the upper Wolfville Formation, which we also place in the Evangeline Member, is present in superposition. The upper Evangeline Member as seen here has a somewhat different lithological character, largely lacking the intraformational conglomerates, with generally smaller fluvial bedforms and numerous deeply rooted palaeosols.

\section{Tectonostratigraphic Sequence III: Blomidon Formation}

TS III in the Fundy basin consists entirely of the Blomidon Formation, with the uppermost part of the formation being part of the overlying TS IV. The larger part of the Blomidon Formation constituting TS III consists of a lower, coarser-grained, largely fluvial and aeolian member, the Red Head Member, and a much thicker upper member, the White Water Member (see Appendix for definitions).

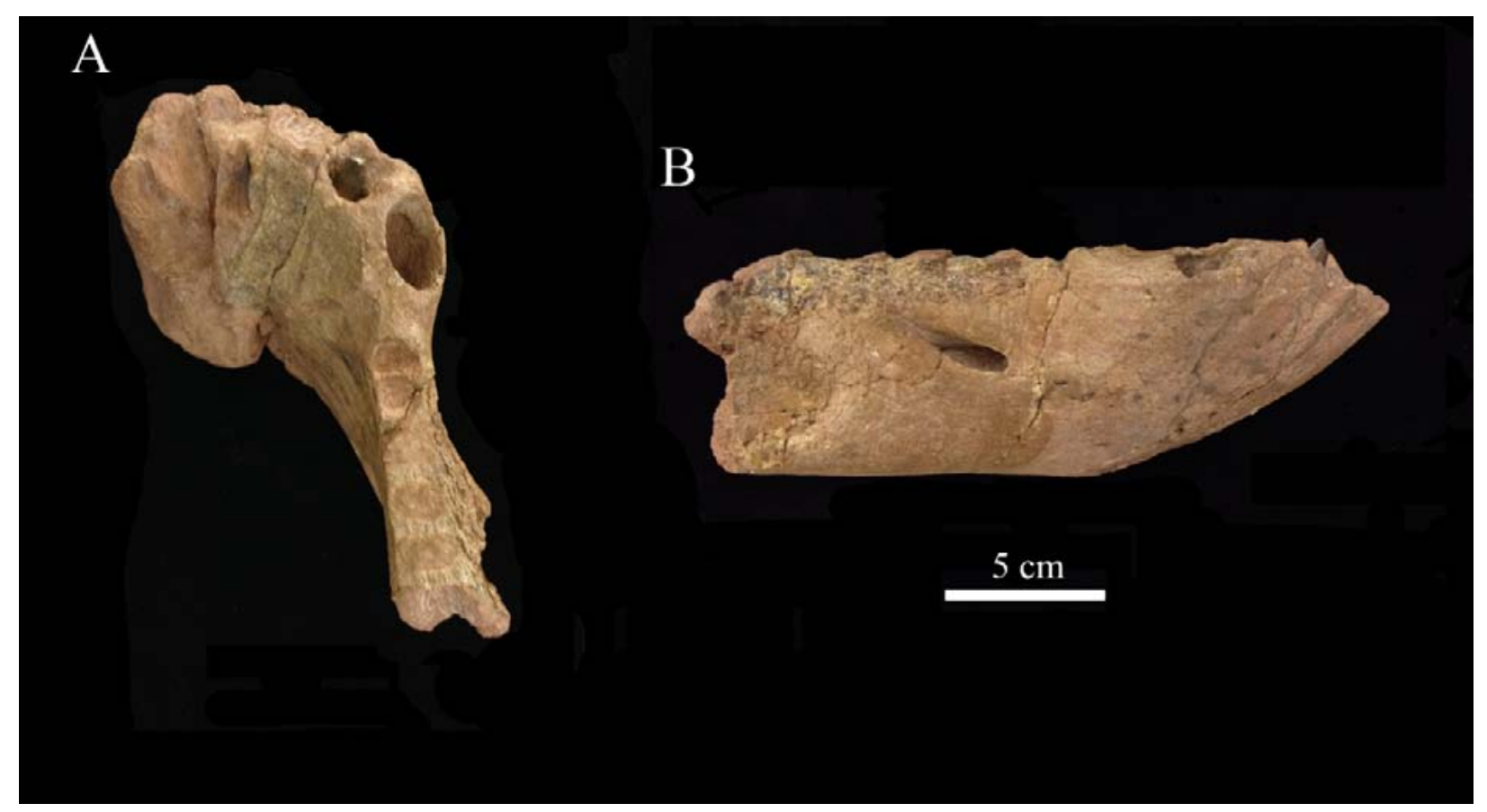

Figure 17. Partial mandible of Arctotraversodon plemmyridon (YPM VPPU 019190, holotype) from the Evangeline Member at Burntcoat. (A) occlusal and (B) right lateral view. 


\section{Red Head Member}

The fluvial and aeolian strata of the Red Head Member are unequivocally exposed in three areas: its type area along the shoreline outcrops of Economy Mountain (Red Head) from Red Head to Lower Economy; at the southern end of Chignecto Provincial Park near Advocate, Nova Scotia; and in the vicinity of Medford, Nova Scotia. Only the last area has yielded tetrapod remains (Figs. 18-19).
Outcrops of the Red Head Member occur in two areas in the vicinity of Medford: on the mainland shore cliffs and foreshore; and at Paddy Island, on the foreshore and along the adjacent mainland shore (Fig. 19). These two areas are separated by a fault with normal displacement of about 30 $\mathrm{m}$ (Olsen et al. 1989). Baird and PEO first discovered the productive areas (Fig. 18A-C) in October 1973 (Baird MS, p. 533). Olsen and Baird (1986) and Olsen et al. (1989, 2005a, b) briefly described these outcrops and their fossil assemblages.
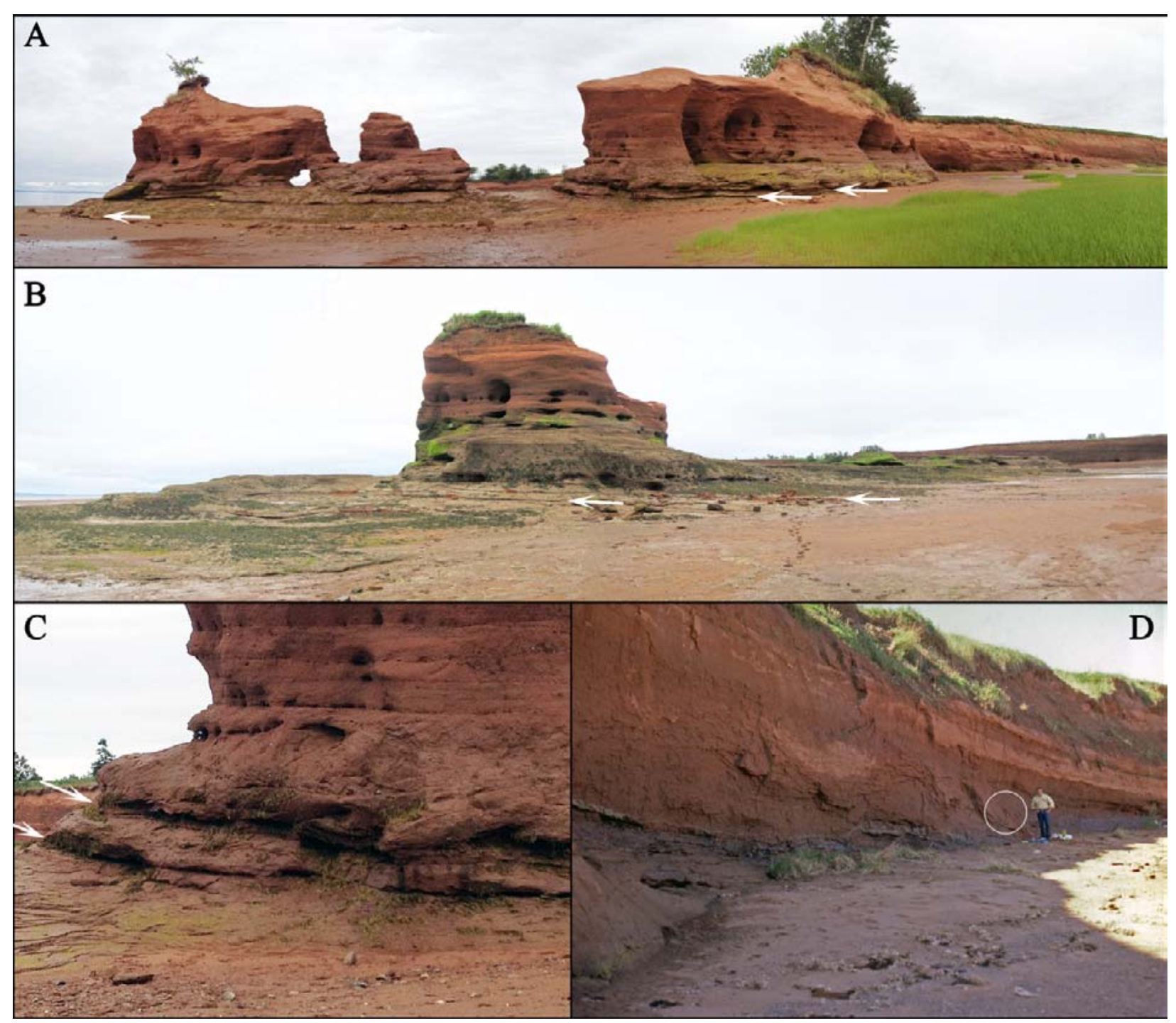

Figure 18. Photos of tetrapod-bearing outcrops of the Red Head Member of the Blomidon Formation along the North Medford shore and Paddy Island. (A) North Medford Shore outcrops with arrows marking three intervals with sandstones bearing abundant tetrapod ichnofossils with the middle layer being the most prolific. (B) Erosional remnant of Paddy Island with arrows marking two intervals with tetrapod ichnofossils, with burrows of the ichnogenus Cynodontipus being the most abundant. (C) Close-up of middle of (A) showing two prominent tetrapod ichnofossil layers, each of which consists of a couplet with red soft mudstone overlying brown sandstone with the lower couplet being the most prolific source of tetrapod ichnofossils. (D) Locality yielding skull and postcranial bones of Hypsognathus cf. H. fenneri (NSM998GF45.1) at the centre of the circle; field trip participant for scale. See Fig. 19B for stratigraphic position of fossil. 


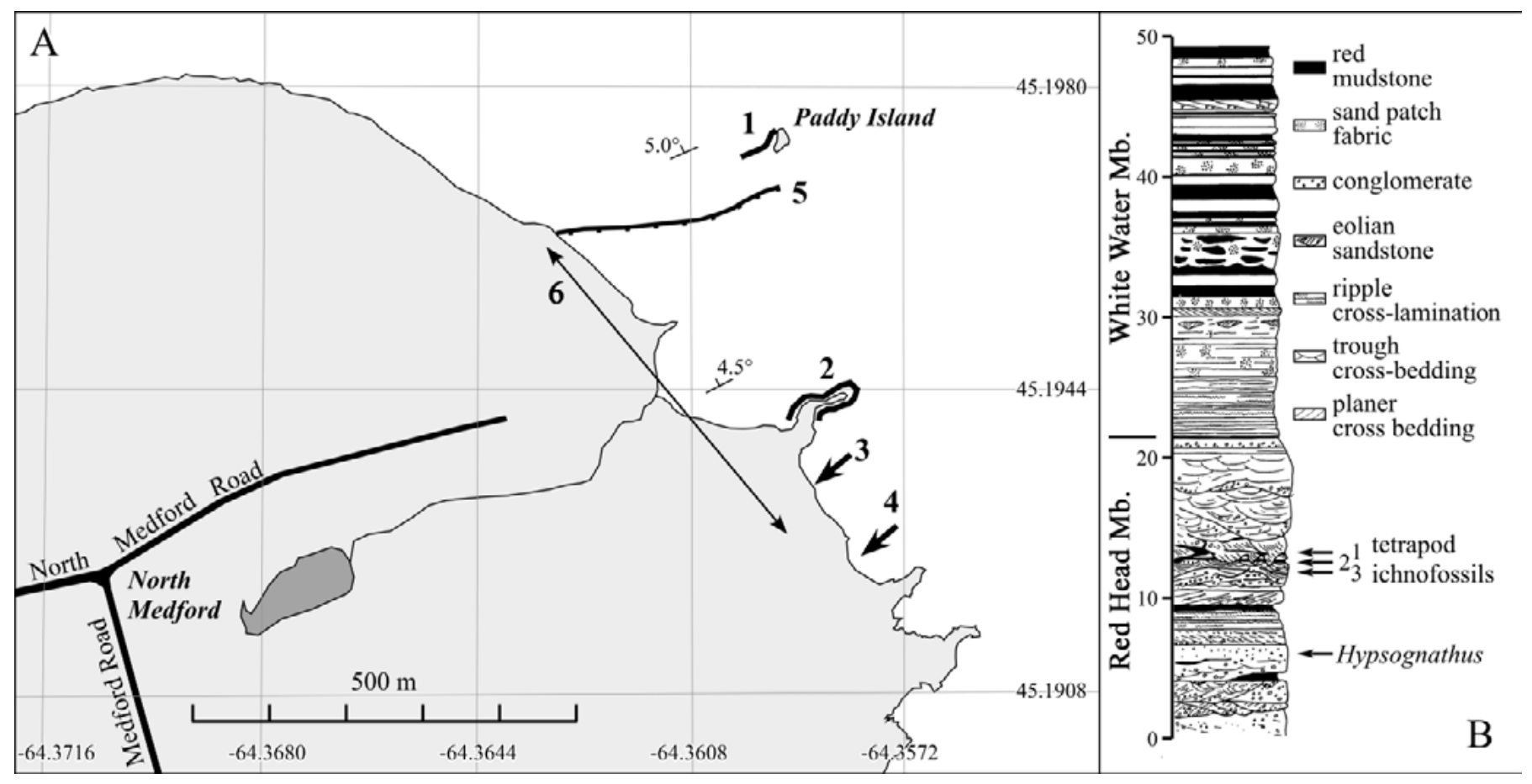

Figure 19. Map and section of North Medford and Paddy Island area. (A) Map of localities (based on Google Earth 2012 image): 1 , tetrapod track localities (thick line) at Paddy Island proper; 2, tetrapod tracks along North Medford shore (thick line, levels 1-3 in [B]); 3, locality with Hypsognathus cf. H. fenneri (NSM998GF45.1); 4, aeolian sand bed (in Fig. 4D); 5, normal fault structurally duplicating track-bearing interval in Red Head Member; 6, scope of section measured along cliff face in (B). All of the fossils are from the intertidal zone. (B) Measured section along North Medford seacliff face: 1, 2 and 3 are track-bearing sandstone-mudstone couplets, with couplet 2 being the most prolific source for footprints (modified from Olsen et al. [1989]).

Locality A, in the Medford cliff outcrops (Fig. 18D), has yielded a skull and a few associated postcranial fragments (including a nearly complete interclavicle) of the leptopleuronine procolophonid Hypsognathus cf. $H$. fenneri (NSM998GF45.1; Sues et al. 2000). Aside from its smaller size, the skull is distinguished from other specimens of Hypsognathus fenneri from the Newark Supergroup in having relatively small quadratojugal 'horns', a proportionately shorter snout, and more open cranial sutures, all of which suggest that it is a juvenile. The specimen was discovered by Alton Brown (then of Arco Petroleum) and collected by PEO during a field trip led by Martha Withjack and PEO in 1983.

Localities $\mathrm{B}$ and $\mathrm{C}$ have yielded a relatively diverse assemblage of trace fossils consisting of both tetrapod burrows and footprints. Cynodontipus was originally considered the track of a hirsute cynodont (Ellenberger 1976), but is now known to represent a tetrapod burrow (unpublished work by PEO, Mohammed Et-Touhami, and Jessica Whiteside). Baird first recorded the presence of this ichnotaxon in 1959, identifying it as a "...problematic double-gouge ichnite...” in his field notes (Baird MS, p.
254). Both terminal burrow bases formed where the animal ended its burrow at a recalcitrant dry mud layer. There are also bedding-parallel traces, where the burrower tunnelled along the interface between dry mud and sand (Fig. 20). The size of burrows varies considerably. The simplest hypothesis is that the burrows were made by Hypsognathus because procolophonids have long been considered burrowing animals (e.g., Groenewald 1991) and this taxon is known from the same horizon. However, especially in view of the variation in size, other burrowing tetrapods may have been involved. Perhaps Cynodontipus-type burrows were made by a variety of tetrapods and represent plesiomorphic digging behaviour at the level of Amniota, using synapomorphybased trace-maker identification (Olsen 1995a; Carrano and Wilson 2001).

Tetrapod tracks from the Red Head Member include Atreipus acadianus (Fig. 21A), Brachychirotherium cf. B. parvum (Fig. 21A), Evazoum sp. (Fig. 21B), and Rhynchosauroides cf. R. brunswickii (Fig. 21C). Most of these tracks occur as natural casts because the underlying mudstones that bear the actual impressions are destroyed during the discovery process. These ichnites are very similar 


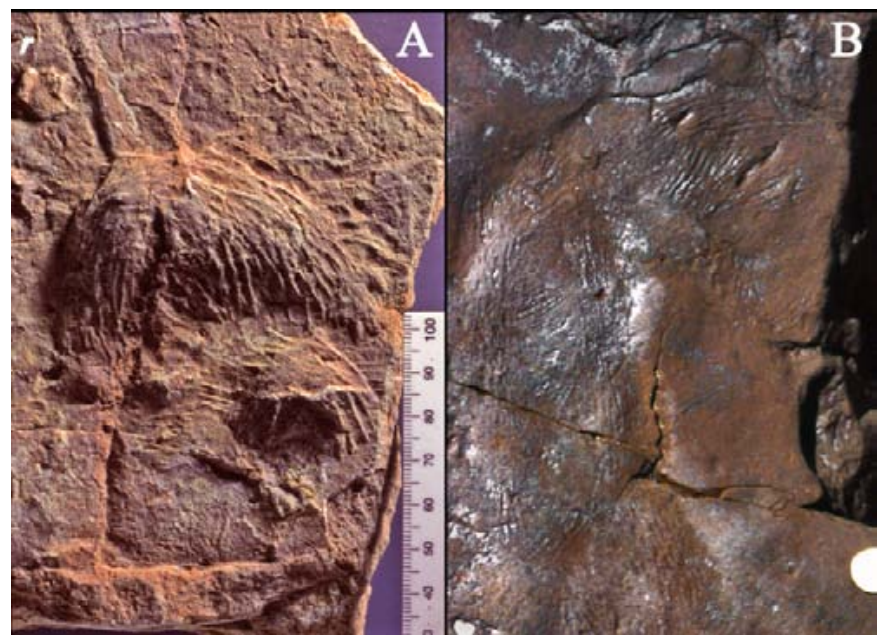

Figure 20. Burrows of Cynodontipus from the Red Head and White Water members of the Blomidon Formation. (A) YPM VP 008264 (in hyporelief), collected by PEO and Donald Baird in 1983 on the North Medford cliff edge ( 2 in Fig. 16A) from the Red Head Member. (B) Uncollected slab from fallen block of the White Water Member, Rossway, Nova Scotia.

to those from the lower and middle Passaic Formation in the Newark basin of New Jersey and Pennsylvania, and several could be conspecific. However, pending a modern revision of the Passaic Formation material, the identifications proposed here must be considered tentative with the exception of Atreipus acadianus, the holotype of which was collected from the Red Head Member at locality C (Olsen and Baird 1986).

The smallest tetrapod tracks from the Red Head Member (Fig. 21C) are virtually indistinguishable from those of Rhynchosauroides brunswickii (Ryan and Willard 1947, as Kintneria; Baird 1957; Olsen and Flynn 1989). Rhynchosauroides cf. R. brunswickii from the Red Head Member is a quadrupedal trackway with a manus impression smaller than that of the pes, although very similar in digital proportions and with the pes generally being less distinctly impressed. The impressions of manual and pedal digit IV generally project the most, with digits III, II, and I being progressively shorter and digit $\mathrm{V}$ short and with a tendency to be recurved. None of the existing specimens shows enough detail to ascertain the phalangeal formula, but, based on other examples of Rhynchosauroides, the phalangeal formulae for both manus and pes are probably 2-3-4-5-3 (e.g., Baird 1957), which is the plesiomorphic count for Amniota. The manus is distinctly smaller than the pes, however, and this appears to be a synapomorphy for Diapsida. Given what we know about Late Triassic continental tetrapods, the most plausible hypothesis is that the trackmaker is a lepidosauromorph such as a rhynchocephalian (Baird 1957) or a small early

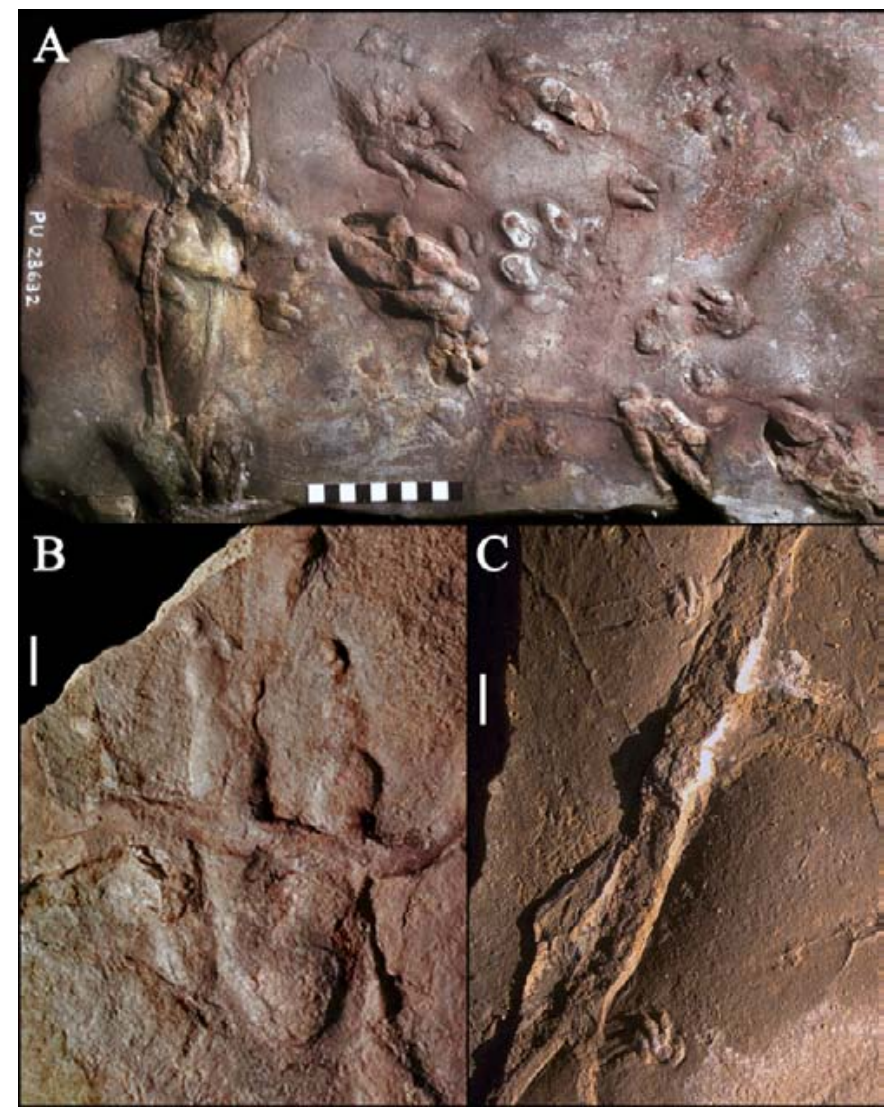

Figure 21. Tetrapod footprints from the Red Head Member of the Blomidon Formation at the North Medford shore outcrops (locality 2 in Fig. 16A). (A) YPM VPPU 023632, collected by PEO party in 1984, with multiple manus-pes sets of Atreipus acadianus (part of topotype; Olsen and Baird 1986), right manus-pes set of Brachychirotherium cf. B. parvum, and poorly preserved ?Rhynchosauroides sp. (scale $=10 \mathrm{~cm}$ : photograph courtesy of the late Donald Baird). (B) Evazoum sp., left pes impression, natural cast (NSM14GF014.008). (C) Rhynchosauroides brunswickii (scale $=1 \mathrm{~cm})$, left manus impressions, natural cast (scale $=1 \mathrm{~cm})$.

archosauromorph. Rhynchosauroides cf. $R$. brunswickii is the most common ichnotaxon in the Red Head Member.

Possible pseudosuchians are represented by quadrupedal trackways very similar to Brachychirotherium parvum (Hitchcock 1889; Baird 1957; Haubold 1971) (Fig. 21A). Baird (1957, p. 473) diagnosed Brachychirotherium parvum as follows: "... phalanges of pes digit $\mathrm{V}$ reduced and included in the metatarso-phalangeal pad; pes digit IV and V clawless; narrow, curved claws on pes digits I to III borne high above the thickly padded plantar surface and divergent laterally; metatarso-phalangeal pads III and IV coalesced."

To this, Baird added this description, "the pedal 
metatarso-phalangeal pads form a straight line of low bosses across the posterior edge of the sole; pedal digit $\mathrm{V}$ is encased in a single pad with no claw; and at least digits IV and V of the manus lacked claws." We identify the tracks from the Red Head Member as Brachychirotherium cf. B. parvum because they resemble Brachychirotherium parvum from the Newark basin in overall proportions and share at least the first three nominally diagnostic characters listed by Baird. The tracks from the Red Head Member appear to have separate metatarso-phalangeal pads for pedal digits III and IV but are smaller than any specimen of Brachychirotherium parvum from the Newark basin; it is possible that the difference in pad shape is size-related. The interpretation of the presence of claws on the manus is complicated by the large number of burrow penetrations on the slabs, some of which occur in positions that could be mistaken for impressions left by manual or pedal claws. However, the best-preserved specimens apparently lack claws on manual digits IV and V. The relatively large manus seems to place both the Red Head specimens and Brachychirotherium parvum from the Newark basin in the 'large manus group' of chirotheriid tracks.

Both the absence of claws of pedal digits IV and V and manual digits IV and V are characters seen minimally in Crocodylomorpha. The distribution of these character states outside that clade is poorly documented, because of both the inadequate preservation of known manus and pedes for many taxa and the difficulty of determining whether a small ungual bore a claw. However, claws were definitely present on digits IV and V of the manus and pes of phytosaurs (as evident in the ichnotaxon Apatopus from the Newark basin) and possibly on pedal digit $\mathrm{V}$ in the early Middle Triassic archosauriform Euparkeria capensis. The minute ungual phalanges of manual digits III through $\mathrm{V}$ and unguals of pedal digits IV and V of the Late Triassic paracrocodylomorph Postosuchus alisonae (Peyer et al. 2008) appear too small and blunt to have borne claw sheaths. The absence of claws on digits IV and V of both manus and pes may represent synapomorphies at some level within the Archosauria, perhaps at the level of Pseudosuchia to the exclusion of Phytosauria.

Unfortunately, the coalescence of manual and pedal phalangeal pads in Brachychirotherium parvum and the Red Head specimens of Brachychirotherium cf. B. parvum precludes determination of the phalangeal formula. However, some members of Pseudosuchia can be ruled out as track makers because of the size of the manus relative to the pes. In at least some paracrocodylomorphs, such as Postosuchus alisonae (Peyer et al. 2008), the manus is relatively smaller than seen in the forms in question. In the Aetosauria, the manus appears relatively larger, although confusion concerning the association of the best manus and pes specimens (see Lucas and Heckert 2011) prevents definitive assessment. Thus the simplest inference is that
Brachychirotherium parvum and the Red Head specimens of Brachychirotherium cf. B. parvum represent either crocodylomorphs or another group of pseudosuchians.

A non-dinosaurian dinosauromorph is represented by the tracks of Atreipus acadianus, the type material of which comes from the Red Head Member at locality C (Olsen and Baird 1986; Fig. 21A). Atreipus acadianus was produced by a habitually quadrupedal tetrapod with a tridactyl pes and a functionally tetradactyl manus. No hallux is evident, even in the deepest impressions, as is also the case in the other North American ichnospecies of Atreipus. Olsen and Baird (1986) argued on phylogenetic grounds that Atreipus was made by either an ornithischian or a member of the sister-group of Dinosauria, which we would now term a non-dinosaurian dinosauromorph. Haubold and Klein (2000), Carrano and Wilson (2001) and Irmis et al. (2007) concurred with this assessment. Subsequently, with the discovery of the dinosauriform Silesaurus from the Late Triassic of Poland (Dzik 2003), it became apparent that at least North American examples of Atreipus also share a potential synapomorphy with Silesaurus to the exclusion of Dinosauria and non-dinosauriform dinosauromorphs. This feature is the distinct reduction in the length of digit I well beyond that seen in basal saurischian dinosaurs but present in the pes of Silesaurus as well as in deeply impressed prints of Atreipus that always lack traces of a hallux. In contrast, deep impressions of Triassic-Early Jurassic brontozoid tracks (sensu Rainforth 2005; traditionally classified as Anchisauripus, Eubrontes and Grallator) always show a trace of the hallux. This suggests that the trackmaker of Atreipus was a member of Dinosauriformes including Silesaurus but excluding Marasuchus, and may well have been a silesaurid, a group now known to have attained a wide geographic distribution during the Triassic (Nesbitt 2011).

Smaller examples of Atreipus acadianus sometimes lack manus impressions, as well as the metatarso-phalangeal impression of pedal digits II and IV that is usually present in North American specimens of Atreipus. Such tracks are easily confused with brontozoid footprints. However, intergradations between all these forms occur even within individual trackways, and thus we think that brontozoid tracks have not yet been found in the Red Head Member and that there is no evidence of coelophysoid theropods in this unit.

The only possible dinosaurian ichnites from the Red Head Member are functionally tridactyl or even didactyl tracks with an unusually elongate digit IV and an apparent trenchant claw on digit II assigned to the ichnogenus Evazoum (Lockley and Lucas 2013; Fig. 21B). This form has previously been referred to as Coelurosaurichnus sp. B (Olsen et al. 1989), "?saurischian dinosaurian track 'new genus 1'" (Olsen and Rainforth 2003) and a 'new dinosaur-like ichnogenus' (Olsen et al. 2005a, b). Lockley et al. (2006) noted the similarity between this form and the 
ichnogenera Evazoum and Kalosauropus. However, in terms of synapomorphy-based reasoning, this similarity is largely based on retention of plesiomorphic features below the level of Dinosauria, in combination with pedal digitigrady and with bipedality. Lockley and Harris (2011) suggested Evazoum was made by a sauropodomorph, but again the resemblances are all symplesiomorphies below the level of the Dinosauria. Without any distinct pedal synapomorphies relating it to a specific group, we can only conclude that Evazoum might represent an early dinosaur, perhaps even a basal saurischian or a gracile sauropodomorph, but nondinosaurian affinities cannot be ruled out.

The overall assemblage of tetrapod tracks from the Red Head Member is very similar at the level of ichnogenus to that from the middle Passaic Formation of the Newark basin. Most ichnospecies from the Red Head Member are also shared with the middle Passaic except for Atreipus acadianus, which is thus far known only from the Red Head Member. Assemblages from the Passaic Formation also include the presence of Evazoum - CU 170.3 and CU 170.4 were figured and misidentified as coming from the Wolfville Formation by Lockley and Lucas (2013) but are actually from Lyndhurst, New Jersey (Olsen and Rainforth 2003). Based on palaeomagnetic polarity stratigraphy, the Red Head Member is coeval with the middle Passaic Formation (Kent and Olsen 2000), and thus a close correspondence in ichnotaxa is not unexpected.

Outcrops along the shores of Economy Point may pertain to the Red Head Member. Eric Leighton found a single archosauriform tooth crown with serrated edges (NSM014GF023.003) at Thomas Cove (at approximately $45.360042^{\circ} \mathrm{N}, 63.917850^{\circ} \mathrm{W}$ ). The strata along this section lie above the unconformity visible on the Consolidated Beacon Resources Ltd. Line 10 seismic profile described in Withjack et al. (2010) and therefore should belong to the Red Head Member. The abundant mud-cracked bedding-plane surfaces in these strata are consistent with this interpretation, although the tooth-producing unit is a calcite-cemented intraformational conglomerate resembling units in the Wolfville Formation.

\section{White Water Member}

Overlying the Red Head Member is the White Water Member (defined in Appendix), which crops out at multiple localities along the shores of the Minas Basin and St. Mary's Bay. Through most of its extent, the White Water Member consists of rhythmically bedded sedimentary packages called sand-patch cycles (Smoot and Olsen 1988; Olsen et al. 1989), which formed largely in playas with efflorescent halite crusts. These rhythmic sediments are devoid of tetrapod remains except for one poorly preserved, possible dinosauromorph track (cf. Atreipus; Fig. 22). However, in the shore outcrops on the north side of St. Mary's Bay, especially at Rossway (Figs. 23-24), the sedimentary cycles have much less development of sand-patch fabric and the section is far more fossiliferous, especially with respect to tetrapods; however, all but one locality there have yielded only trace fossils.

Cynodontipus burrows found in the Rossway section may have been produced by procolophonid parareptiles. One particularly informative specimen, found by Jessica Whiteside but unfortunately not collected because of its large size, intertidal location and time constraints, resembles the complex burrow systems reported by Voigt et al. (2011) from the Aglegal Member of the Timezgadiouine Formation of the Argana Basin in Morocco. The Rossway specimen, though, also had clear Cynodontipus-type crescent-shaped scratch marks in positive hyporelief directly attached to the burrows, demonstrating their connection.

One example of Rhynchosauroides sp. was found but not collected by PEO and figured by Olsen et al. (2005a, b; Fig. 24F). It is larger than specimens of Rhynchosauroides brunswickii from the Red Head Member, but additional material is needed for more precise ichnotaxonomic identification. As is the case with the tracks from the Red

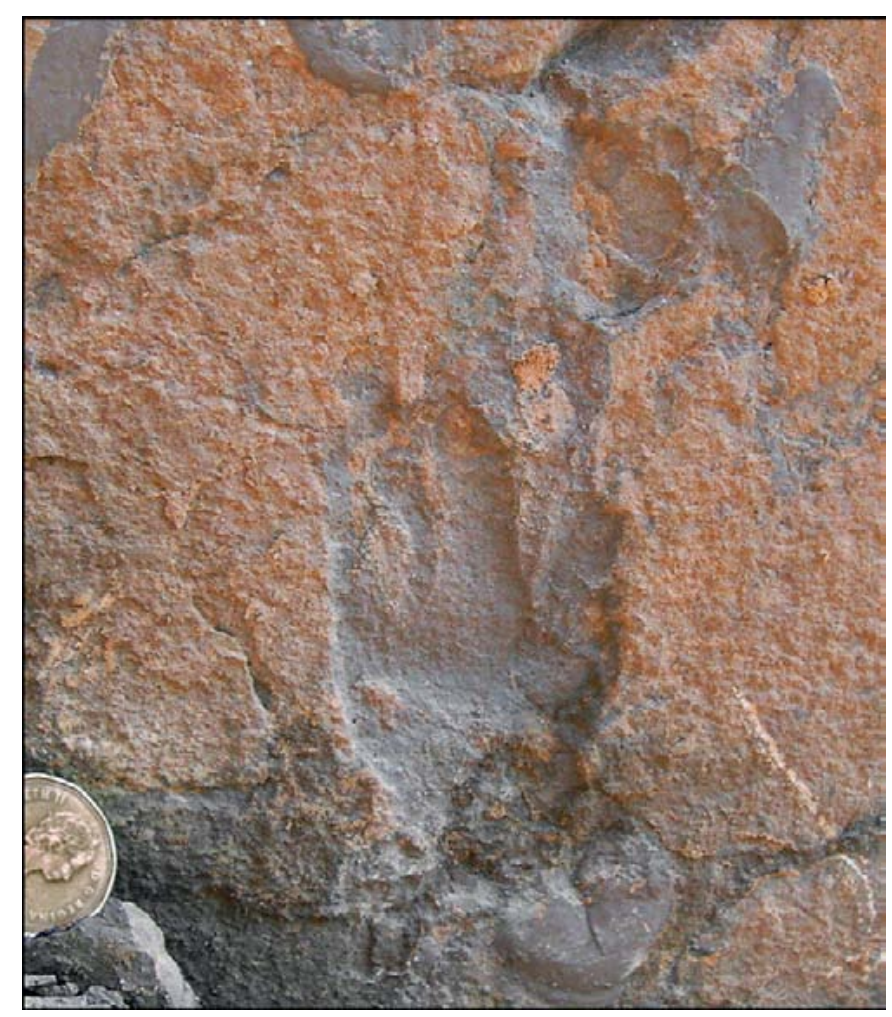

Figure 22. Possible dinosauromorph footprint from fallen block of the White Water Member of the Blomidon Formation of Five Islands (Red Head) found by Jessica Whiteside in 2006. Canadian one-dollar coin is $26.5 \mathrm{~mm}$ in diameter. 


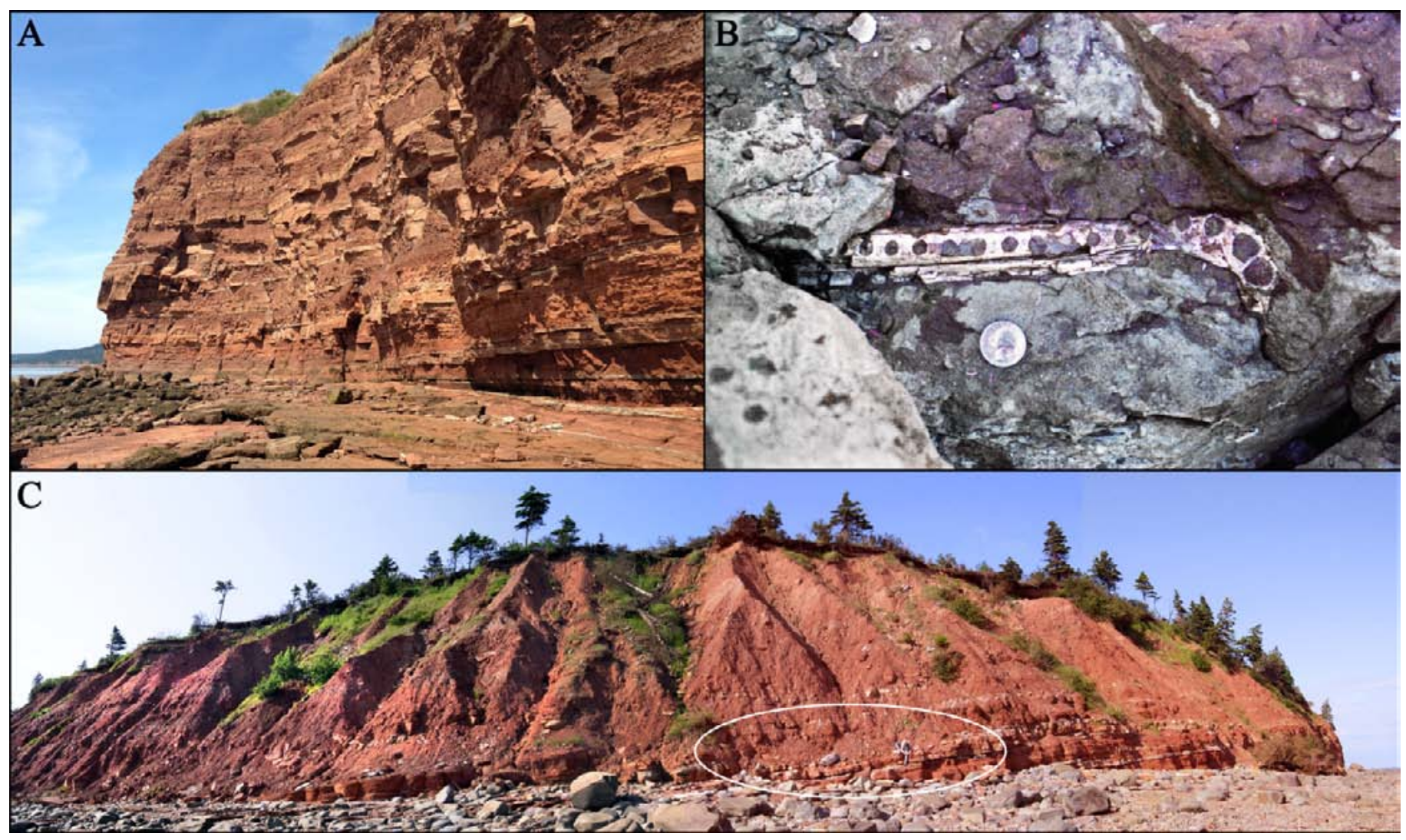

Figure 23. Outcrops of the cyclical, largely lacustrine White Water Member of the Blomidon Formation at Rossway, on St. Mary's Bay, Digby County, Nova Scotia. (A) Cliff exposures at $44.5740^{\circ} \mathrm{N}, 65.9202^{\circ} \mathrm{W}$. This is the main area for tetrapod ichnofossils from multiple levels, mostly in fallen blocks, but sometimes in situ in the intertidal zone (locality 5 in Fig. 2F). (B) partial phytosaur jaw as preserved in situ in 1974. (C) composite photo of phytosaur locality, with Jessica Whiteside for scale (in oval at $44.569828^{\circ} \mathrm{N}, 65.908300^{\circ} \mathrm{W}$ : locality 4 in Fig. $2 \mathrm{~F}$ ).

Head Member, Rhynchosauroides sp. from the White Water Member may represent the tracks of a lepidosauromorph.

The prenarial portion of the cranium of a slendersnouted phytosaur (YPM VPPU 007920), with an associated osteoderm and bone fragments, was found by PEO, Bob Salvia and A. Heimlich in 1974 and represents the only skeletal tetrapod remains yet found from the White Water Member (Fig. 25). This is the only known specimen of a phytosaur from the Fundy basin and the first record of this group from Canada. It is a phytosaurid and was initially identified as Rutiodon sp. (Olsen et al. 1989). However, no synapomorphies have been identified to date that would link the specimen from the Blomidon Formation with the geologically considerably older Rutiodon carolinensis.

One example of cf. Brachychirotherium sp. (Fig. 24E) suggests the presence of Pseudosuchia in the White Water Member, but this specimen is rather indistinctly preserved and not identifiable at a lower ichnotaxonomic level.

Possible silesaurid ornithodirans are represented by several pes impressions. These closely resemble Atreipus milfordensis in their distinctive 'tulip' shape (Fig. 24D). However, they all lack definitive manus impressions, and thus identification is somewhat uncertain.

The Rossway locality is noteworthy for having yielded the only definitive brontozoid footprints from strata below the basalt in the Fundy basin, and thus they represent the only pre-basalt evidence for theropod dinosaurs in this region. Two large slabs were found (PEO, Amy Litt, and Louise Roth in August 1976; PEO and Dan Simanek in July 1978), but neither could be collected (Fig. 24A-B). The brontozoid tracks have a proportionately long pedal digit III, with (when well-preserved) well-developed pads, especially the most distal, a relatively narrow pes with low angulation, and a tendency for the metatarso-phalangeal pad of digit IV not to leave an impression. Following the classification of Lull (1953), these tracks would be identified as Anchisauripus sillimani or Anchisauripus tuberosus but, as Olsen et al. (1998) argued, the proportional features traditionally employed to differentiate the ichnogenera Anchisauripus, Grallator and Eubrontes are size-related along 


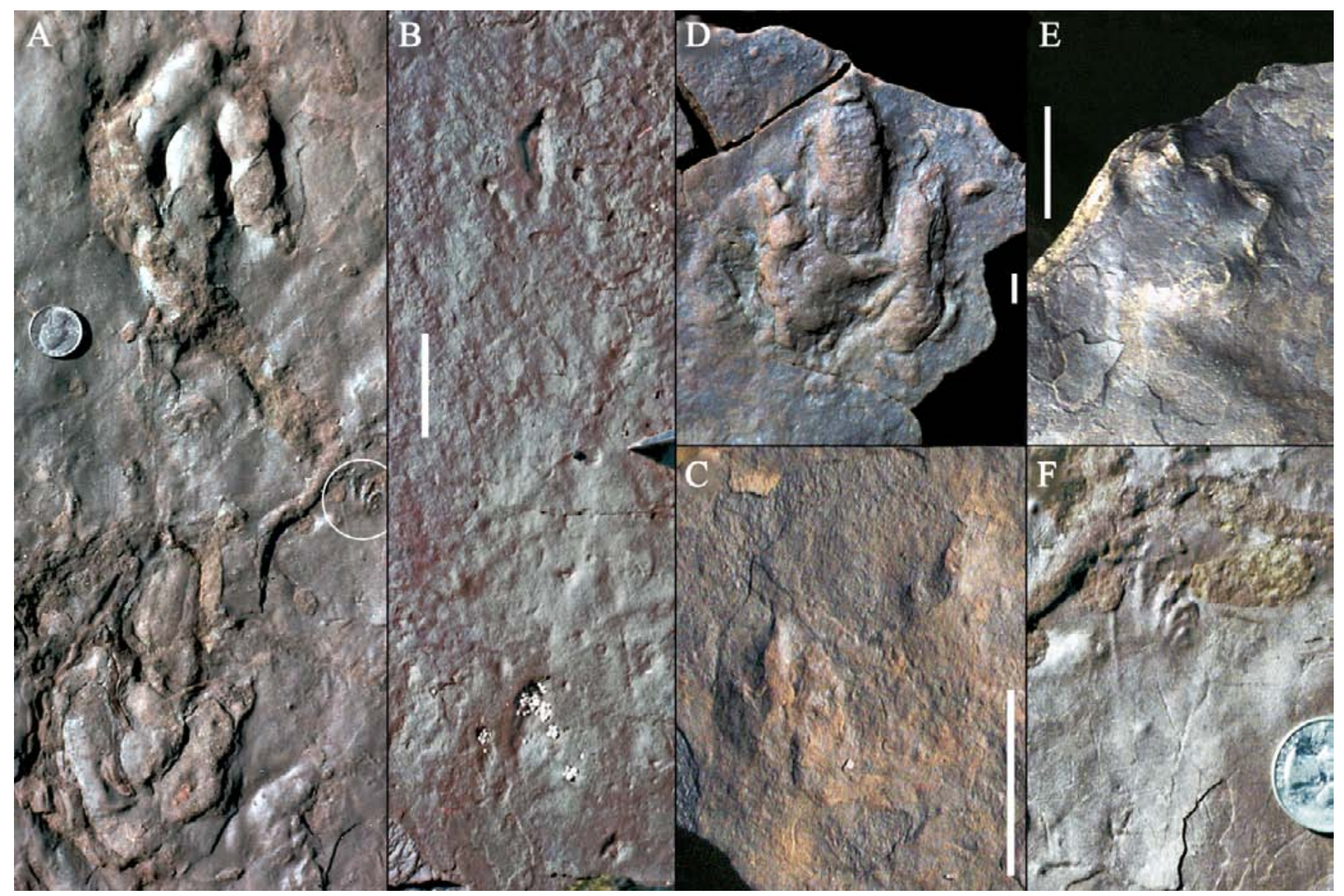

Figure 24. Tetrapod ichnotaxa from the White Water Member at Rossway, Nova Scotia (locality 5 in Fig. 2F). (A) Brontozoid footprints (Anchisauripus cf. A. tuberosus) (US 25-cent coin is $24.26 \mathrm{~mm}$ in diameter), circle shows position of footprint enlarged in (F) in natural cast on fallen block (not collected). (B) small possibly brontozoid (Grallator) footprints in situ in intertidal zone (not collected). (C) small, possibly brontozoid (Grallator) footprints, natural cast in fallen block (scale $=10$ $\mathrm{cm}$ ). (D) Atreipus cf. A. milfordensis, pes impression, natural cast, fallen block (scale $=1 \mathrm{~cm})$. (E) cf. Brachychirotherium sp., manus impression, natural cast (scale $=5 \mathrm{~cm}$; NSM014GF014.006). (F) Rhynchosauroides sp., detail of (A) (scale as in A).

a morphological continuum. Identification as theropod tracks is based on their functionally tridactyl nature, with a distinct hallux (not actually seen in these specimens), and full bipedality. However, it is possible that some as yet unknown non-dinosaurian dinosauriforms had a similar foot structure that, based on tracks, might not be separable from that of theropods. However, the fact that identical footprints occur in Early Jurassic strata from which no nondinosaurian dinosauriforms are known and in which the only plausible makers of brontozoid tracks are theropod dinosaurs lends support to the original identification.

In overall composition, the footprint assemblage from the Rossway locality most closely resembles that from the lower part of the upper Passaic Formation (roughly between the Metlars Member and Member OO; Olsen et al. 1996) in the presence of medium-sized brontozoid tracks but with
Atreipus still present. This would correlate with the lower to middle White Water Member on the Medford shore, east at Blomidon, above the level of the Red Head Member track assemblage. There is as yet no independent test for this hypothesized correlation.

Tectonostratigraphic Sequence IV: uppermost Blomidon and McCoy Brook formations

\section{Partridge Island Member}

The top of the Blomidon Formation consists of a less than $10 \mathrm{~m}$ thick but distinctive set of beds here named the Partridge Island Member (see Appendix). Although no evidence of tetrapods has been recovered yet from this 


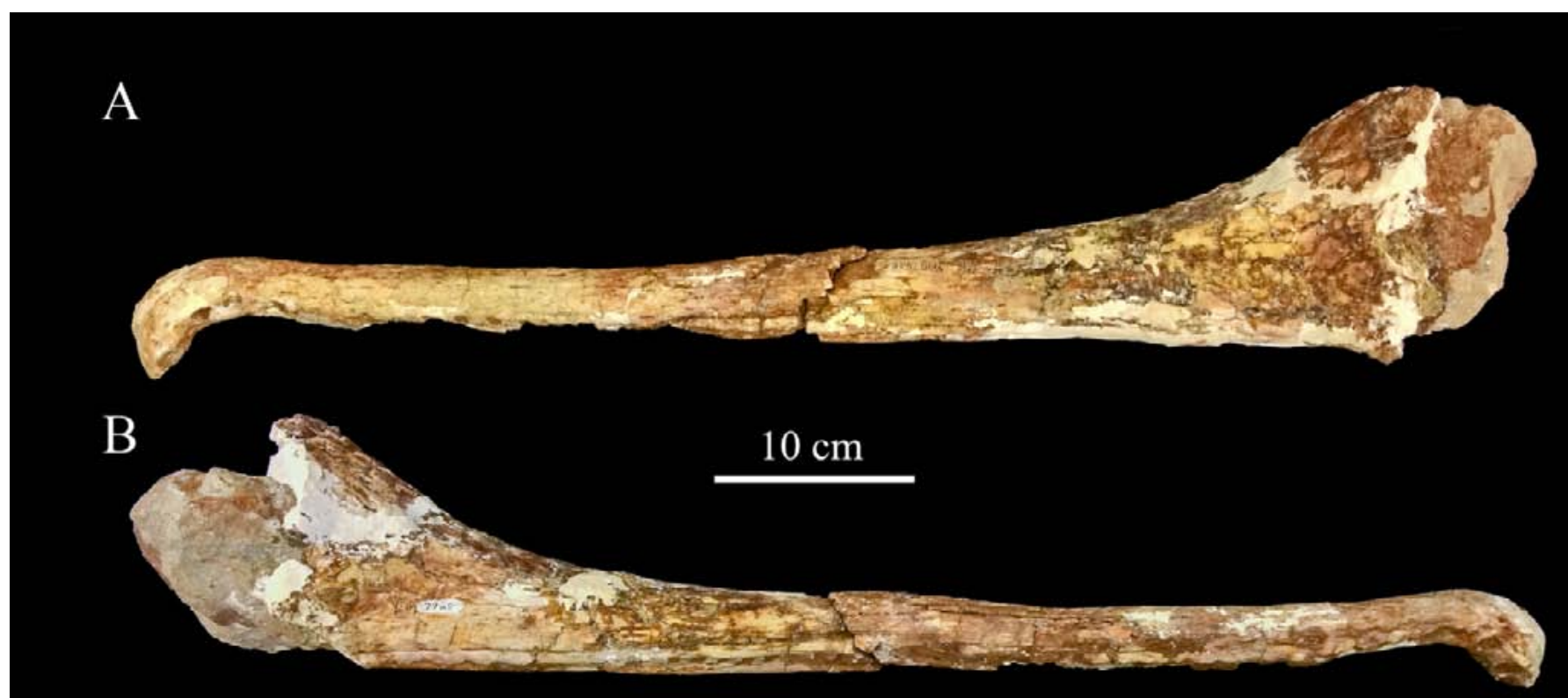

$\mathrm{C}$

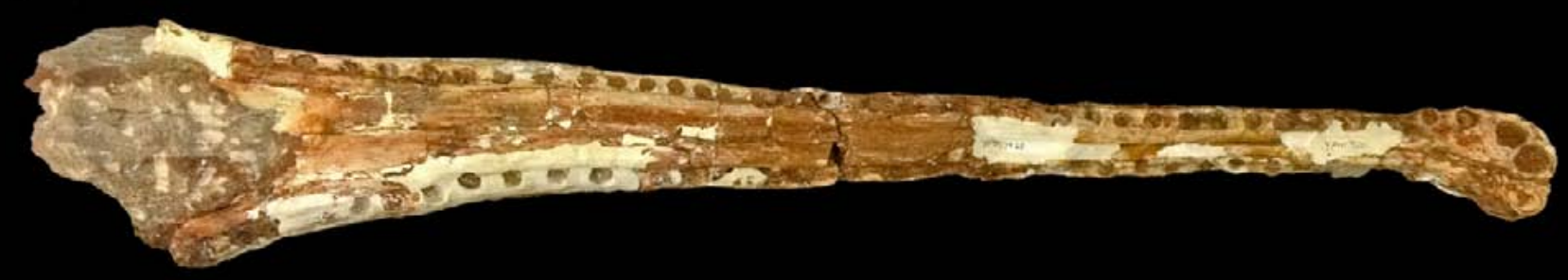

D

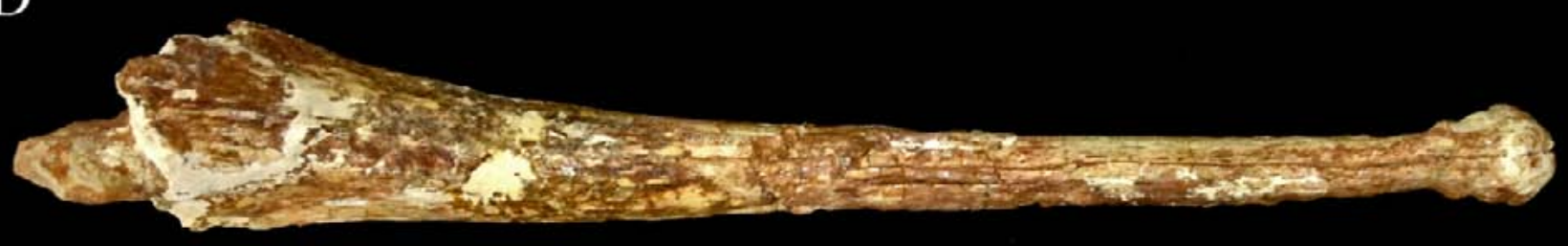

Figure 25. Prenarial portion of the cranium of a longirostrine phytosaur (YPM VPPU 007920) from the White Water Member of the Blomidon Formation at Rossway, on St. Mary's Bay, Digby County, Nova Scotia (locality 4 in Figs. 2F). (A) Left lateral, (B) right lateral, (C) ventral and (D) dorsal views.

unit, it requires some discussion because it is important in understanding the chronology of faunal changes across the Triassic-Jurassic transition. At its type section, the Partridge Island Member consists of about $1 \mathrm{~m}$ of interbedded red, purple, grey, and black (variegated) mudstone and minor carbonates that have proven critical to the interpretation of the end-Triassic extinction (e.g., Blackburn et al. 2013). The unit contains pollen and spores at several levels, documenting the initial phase of the end-Triassic extinction (Fowell and Traverse 1995; Whiteside et al. 2007; Cirilli et al. 2009), has three modest iridium anomalies (Tanner and Kyte
2005; Tanner et al. 2008; Kyte et al. 2008), and contains the upper part of palaeomagnetic polarity chron E23r (Deenen et al. 2011), which extends downward into the uppermost portion of the White Water Member (see Appendix). Based on zircon U-Pb dates, the age of the Partridge Island Member is latest Rhaetian at $201.564 \pm 0.015 \mathrm{Ma}$ (Blackburn et al. 2013). Although Olsen (1997) and Olsen et al. (2005a, b) interpreted the Partridge Island Member as comprising the base of TS IV, it rests conformably on the underlying Blomidon Formation (contra Kozur and Weems 2010) as shown by the position of E23r (Deenen et al. 2011) (see 
discussion in Appendix).

Facies typically bearing pollen and spores indistinguishable from the type section characterizes the Partridge Island Member over a large area of the Fundy basin - minimally $460 \mathrm{~km}^{2}$ as described by Olsen and EtTouhami (2008) and contra Kozur and Weems 2010 (see Appendix). However, at some localities such as just east of the The Old Wife in Five Islands Provincial Park, the overlying North Mountain Basalt metamorphosed strata of this unit (which Kozur and Weems 2010 interpreted as a palaeosol - see Appendix). Although locally beds in this member appear promising for the presence of tetrapod tracks, no footprints have been found to date.

\section{North Mountain Basalt}

There are no exposures of definitive sedimentary interbeds within the North Mountain basalt, with all known possible examples being more parsimoniously identified as void fillings within or between flows (Olsen et al. 2012) that postdate the basalt and hence are considered part of the McCoy Brook Formation (see below). Consequently, there are no occurrences of tetrapods from this basalt formation. However, the basalt does contribute to the chronology of events through the Triassic-Jurassic transition because it is one of the few CAMP units for which there are highprecision U-Pb dates $(201.566 \pm 0.031 \mathrm{Ma}$; Blackburn et al. 2013).

\section{McCoy Brook Formation}

Although Donohoe and Wallace (1978) first used the name McCoy Brook Formation it was formally defined by Tanner (1996), who provided a measured type section. The formation consists primarily of red clastic rocks and conformably overlies the North Mountain Basalt. However, a widespread, generally grey, white, green, and purple carbonate-rich unit, the Scots Bay Member (Powers 1916; Tanner 1996), forms the base of the formation at most outcrops and below much of the Bay of Fundy.

Locally, especially along the Minas fault zone, the relationship between the McCoy Brook Formation and
North Mountain Basalt is complex not only due to postdepositional faulting but also because of sedimentation during faulting (Olsen et al. 1989; Olsen and Schlische 1990; Tanner and Hubert 1991). Probably related to the syntectonic sedimentation is the fact the McCoy Brook Formation is by far the most tetrapod-rich stratigraphic unit of the Fundy Group, with every major outcrop yielding tetrapod bones, or tracks, or both. From west to east along the north shore of Minas basin and then to the south to Scots Bay, important localities with outcrops of the McCoy Brook Formation are: 1) Wasson Bluff Protected Area; 2) McKay Head; 3) Blue Sac west; 4) Blue Sac east; 5) Five Islands Provincial Park; and 6) coves along the southern shore of Scots Bay. et al.

Wasson Bluff Protected Area. Cliff and foreshore outcrops between Wasson Bluff and Swan Creek contain by far the greatest wealth of early Mesozoic tetrapod remains in the Fundy basin. Dawson (1855, fig. 7) illustrated this section, which he had studied in 1846 and 1850. Describing the Wasson Bluff to Swan Creek section, Dawson (1855, p. 87) wrote, "...the coast exhibits the interesting and complicated appearances which I have endeavoured to represent in [his] Fig. 7." (We reproduce Dawson's diagram here as Fig. 26.) His description is easy to follow, and he noted a place of special interest at Wasson Bluff: "Opposite the Two Islands, the fissures of the trap are lined with fine crystals of analcime and natrolite; and the fissures and vacant spaces of the trap conglomerate in the same neighbourhood contain a reddish variety of chabasie [chabasite] in rhombohedrons, often of large size" (Dawson 1855, p. 89). The latter clearly refers to the basalt talus breccias at locality a (Figs. 28-29), which is the most consistently fossiliferous location in the Wasson Bluff area. However, Dawson did not report fossils from this section.

PEO first discovered postcranial remains of a sauropodomorph dinosaur in sandstones of the McCoy Brook Formation at Wasson Bluff in August 1976 as part of a team from Princeton University led by Donald Baird (Fig. 27). Following his find of an incomplete but excellently preserved skull of a sphenodontian lepidosaur in 1984 (Fig. 31A), PEO and Neil Shubin (then at Harvard University) secured funding for more extensive reconnaissance. This effort led to the discovery of several vertebrate-bearing

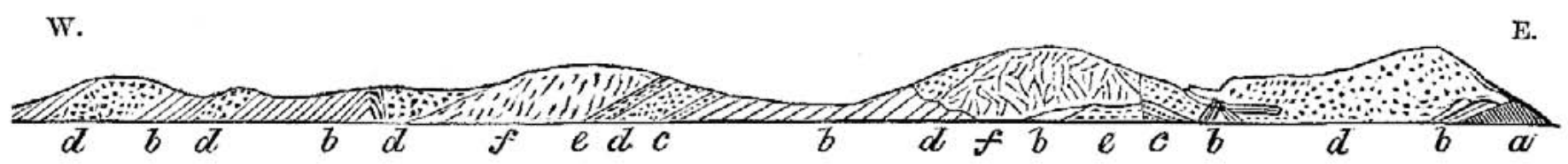

(a) Shales and Sandstone of Carboniferous System, dip. E.N.E.

(b) New Red Sandstone, dips to S.W. (d) Trap Conglomerate and Brecia. (c) New Red Sandstone with fragments of Trap.

(e) Amygdaloidal Trap. $\quad(f)$ Crystalline Trap.

Figure 26. Dawson's (1855, fig. 7) diagram of the section from Wasson Bluff to Swan Creek. 

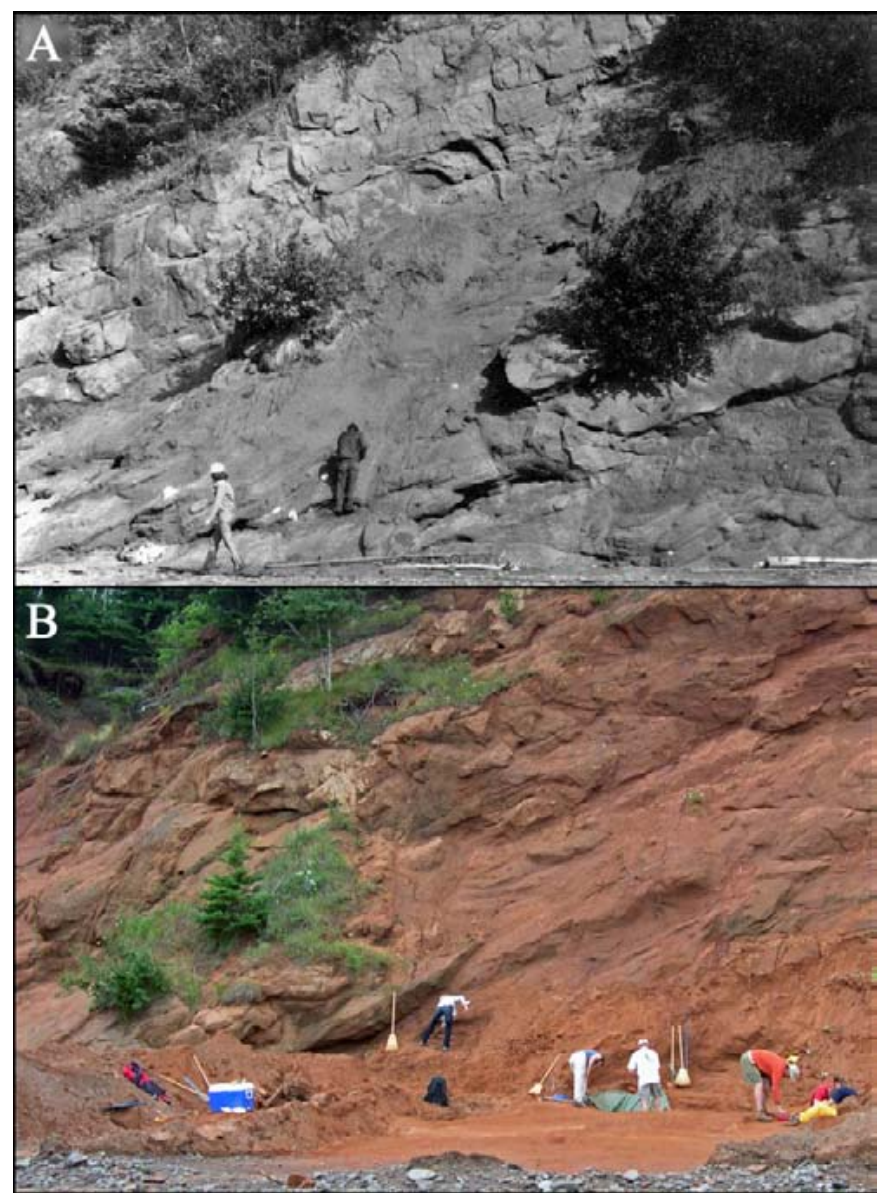

Figure 27. The main sauropodomorph locality at Wasson Bluff: (A) being worked by Baird team including Jack Horner (leaning against cliff) and PEO (wearing hard hat) in 1976 (photo by the late Donald Baird): and (B) being developed as a quarry by a team led by Tim Fedak in 2006. This area is locality $\mathrm{f}$ in Fig. 28A.

deposits at Wasson Bluff (Fig. 28) between 1985 and 1988; important new material continues to be found there on a regular basis. Seven stratigraphic levels representing as many major distinct depositional environments occur in the section. The oldest is an orange aeolian sandstone overlain by a basalt talus slope breccia with red sandy mudstone deposited in the eastern micro-graben against fault scarps of the North Mountain Basalt (Fig. 28A, locality a). The basal sandstone has yielded a few sphenodontian bones (cf. Clevosaurus), but the stratigraphically highest exposed talus breccias (first discovered by William Amaral, Chuck Schaff, Neil Shubin, and H-DS in July 1985) have yielded hundreds of mostly fragmentary but often well preserved bones (Figs. 29C, 32C). Particularly common are skeletal elements and osteoderms of the crocodyliform Protosuchus micmac, including the holotype (Sues et al. 1996), followed by rare remains of the tritheledontid cynodont Pachygenelus cf. $P$. monus (Shubin et al. 1991).

A small right maxilla was tentatively attributed to Crocodylomorpha (Shubin et al. 1994), but its affinities remain uncertain because it lacks diagnostic features. Possible dinosaurian remains have also been found. This is the easternmost chabasite locality labelled 'c' by Dawson (1855, fig. 7) (Fig. 26).

The crocodyliform Protosuchus micmac is known from an incomplete skull (FGM999GF64; Fig. 32A-B), a well-preserved braincase (MCZ 9115), isolated cranial and postcranial bones including numerous osteoderms (Sues et al. 1996). Diagnostic features separating it from other species of Protosuchus include the consistent presence of two caniniform teeth (rather than one) in each dentary and the slender rather than deep anterior process of the jugal extending below the orbit (Clark 1986; Gow 2000). The type species, Protosuchus richardsoni, is known from the upper part of the Dinosaur Canyon Member of the Moenave Formation (Early Jurassic) of Arizona (Colbert and Mook 1951; Clark 1986). A closely related species, Protosuchus haughtoni, occurs in the Upper Elliot and Clarens formations (Early Jurassic) of southern Africa (Busbey and Gow 1984; Clark 1986; Gow 2000).

The tritheledontid Pachygenelus cf. P. monus is known from incomplete cranial and mandibular elements, as well as isolated postcanine teeth from the talus breccia (Shubin et al. 1991). Its postcanine teeth are virtually indistinguishable from those of Pachygenelus monus from the Upper Elliot Formation of southern Africa (Gow 1980). The upper postcanines have a tall principal cusp that is flanked by a smaller, slightly lingually displaced cusp mesially and distally. A labial cingulum links the two smaller cusps. A previously unreported partial right maxilla (MCZ 9137) preserves a canine, five postcanine teeth and two empty postcanine alveoli. The labiolingually compressed lower postcanines have a principal cusp that is followed by smaller accessory cusps distally, and a lingual cingulum (Fig. 33).

Overlying the talus-slope breccia in the middle minigraben, as we interpret it, are largely tabular, lacustrine sandstones, mudstones, and limestones of the Scots Bay Member. At one important locality in the western minigraben (Fig. 28A, locality c), the Scots Bay Member laps onto a faulted basalt surface (Fig. 30). Over most of its extent at Wasson Bluff, the Scots Bay member has a single bed of purple green and white limestone and calcareous sandy mudstone that contains disarticulated remains of the holostean fish Semionotus and unidentified palaeonisciforms, teeth of hybodont sharks, and coprolites. However, where this unit intersects the faulted basalt, there is a talus-slope breccia, the matrix of which is a red and purple mudstone rich in fish bones and scales and with relatively common isolated tetrapod remains. The most common tetrapod fossils are teeth referable to small ornithischians 


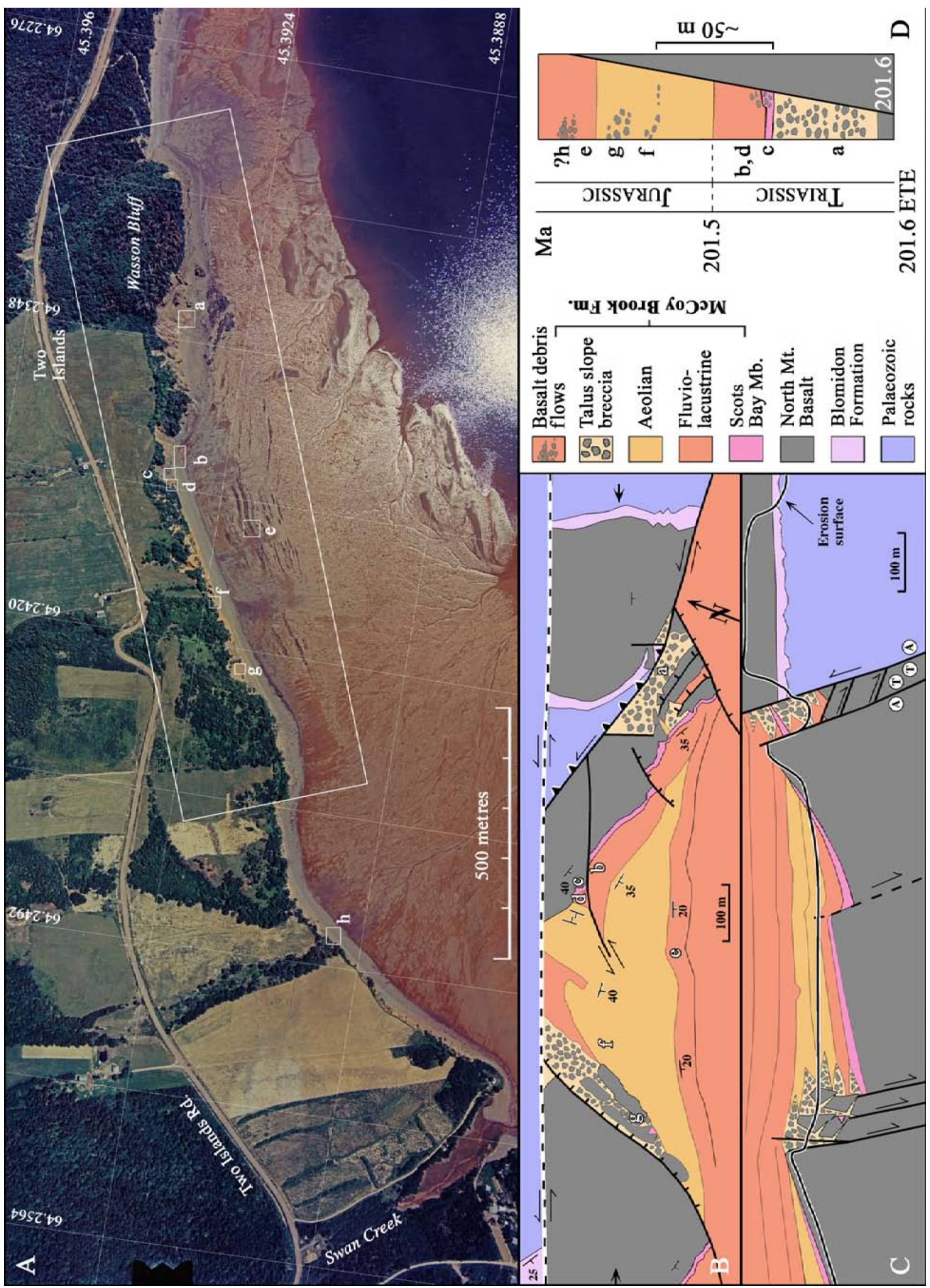


Figure 28. (previous page) Maps, cross-section and columnar section of Wasson Bluff area between the east side of Wasson Bluff and Swan Creek. (A) Aerial photograph with scale and latitude and longitude from Google Earth showing locations of major tetrapod occurrences denoted by boxes and letters (same letters also used for B and D in this figure): a, basalt talus deposit dominated by remains of Protosuchus micmac (including holotype); b, fluviolacustrine sandstone dominated by Clevosaurus bairdi (including two partial skeletons) and Protosuchus micmac (including the skull illustrated in Fig. 32); c, Scots Bay Member onlap onto faulted North Mountain Basalt with talus-slope breccia dominated by disarticulated remains of the holostean fish Semionotus sp., but also producing ornithischian teeth, possible small theropod teeth, protosuchid bones, a tooth-bearing dentary fragment of the tritylodontid Oligokyphus, cynodont postcranial bones, teeth and fin spines of hybodont sharks, and fragments of unidentified palaeonisciform fishes; $d$, same sandstone sequence as b (but offset by east-striking left lateral fault) dominated by Clevosaurus bairdi (including the holotype) and Protosuchus micmac, with much less common remains of Pachygenelus cf. P. monus; e, foreshore outcrops of fluviolacustrine sandstone producing brontozoid (cf. Anchisauripus) tracks attributed to theropod dinosaurs; f, interdune deposit with sauropodomorph dinosaurs discovered in 1976; g, interdune and basalt talus breccia with fragmentary probable sauropodomorph dinosaur with gastroliths; $h$, location of piece of float bearing articulated ventral osteoderms of a protosuchid, lithologically similar to adjacent red palaeosol intervals interbedded with basalt debris flows. (B) Map of eastern three-quarters of outcrops at Wasson Bluff including the eastern mini-graben (around a) and the middle mini-graben (b-f) (lithology key in D; left and right arrows show position of cross-section shown in C) (modified from Olsen et al. 2005a, b, with corrected scale). (C) Interpretive cross-section (left and right arrows in B) (modified from Olsen et al. 2005a,b). (D) Key and synthetic composite section of Wasson Bluff area. Note that nowhere does this complete section occur with all its components in superposition; rather they are tied together by the Scots Bay Member, which occurs at all the sections (ages derived from Blackburn et al. 2013 and rounded to the nearest $100 \mathrm{ka})$.

and possible theropods, followed by bones and osteoderms of Protosuchus, and bones of cynodont therapsids including a tritylodontid dentary and limb bones.

Fedak et al. (in press) described a fragment of a right dentary with a molariform postcanine tooth followed by two empty alveoli posteriorly (NSM012GF014.006). This specimen is referable to the tritylodontid cynodont Oligokyphus based on the presence of two longitudinal rows with three distinct cusps each on the molariform. The tooth closely resembles those of Oligokyphus sp. from the Kayenta Formation (Early Jurassic: Pliensbachian) of Arizona (Sues 1985) in the presence of a distinct cingular cusp at the anterior (mesial) end of each row of cusps and pronounced perikymata on the enamel. Originally known only from two isolated postcanine teeth from the RhaetoLiassic of southern Germany (Hennig 1922), Oligokyphus has subsequently been recorded from Early Jurassic strata in southwestern Britain (Kühne 1956), Arizona (Sues 1985), and Yunnan (China; Luo and Sun 1994). Fedak et al. (in press) also reported on a right humerus (NSM014GF014.002; Fig. 33C) and a partial right ulna (NSM014GF014.003; Fig. 33D) first illustrated by Olsen et al. (2005a, fig. 20G-H) closely resemble the corresponding bones in Oligokyphus (Kühne 1956). The deltopectoral crest and entepicondylar end of the humerus (length: $37 \mathrm{~mm}$ ) are damaged, but the element is otherwise well preserved. The humerus lacks an ectepicondylar foramen, a condition shared by Tritylodontidae and Mammaliaformes, but not Tritheledontidae (Martinelli et al. 2005). The ulna (preserved length: $22 \mathrm{~mm}$ ) lacks its distal end and the radial facet. It has a well-developed olecranon process and a distinct insertion scar for the brachialis muscle just distal to the sigmoid notch. This ulna could belong to a tritylodontid, a tritheledontid or a mammaliaform. Finally, the proximal portion of a small right ischium (NSM014GF014.004; Fig. $33 \mathrm{E})$ has an acetabular facet that is separated from the articular contact with the pubis by a deep, narrow groove. Based on this feature, this bone can also be referred to a tritylodontid, a tritheledontid or a mammaliaform.

Although two different groups of very mammal-like non-mammalian cynodonts are known from the McCoy Brook Formation, no diagnostic skeletal remains of mammaliaforms have yet been recorded from this unit. Their presence would not be unexpected because mammaliaforms occur in more or less coeval strata elsewhere.

The fish-scale-rich, tetrapod-bearing mudstone matrix around basalt clasts is most simply interpreted as a wavesorted shoreline lag. A remnant of probably the same unit was preserved in a small (metre-scale) pocket attached to a giant basalt clast on the westernmost edge of the middle mini-graben, evidently as part of a rider block on the master fault on the west side of the half graben (Olsen et al. 2005a, b).

Isolated tooth crowns from the fish-scale-rich mudstone of the Scots Bay Member (tooth: NSM014GF014.001, Fig. 34C; impressions of teeth: YPM VP 008668, VP 008691) closely resemble those of the teeth of the basal ornithischian dinosaur Lesothosaurus diagnosticus from the Upper Elliot Formation of southern Africa (Sereno 1991). However, these resemblances are plesiomorphic in nature (Sereno 1991), and the teeth from the Scots Bay Member cannot be identified more precisely than Ornithischia. Some 


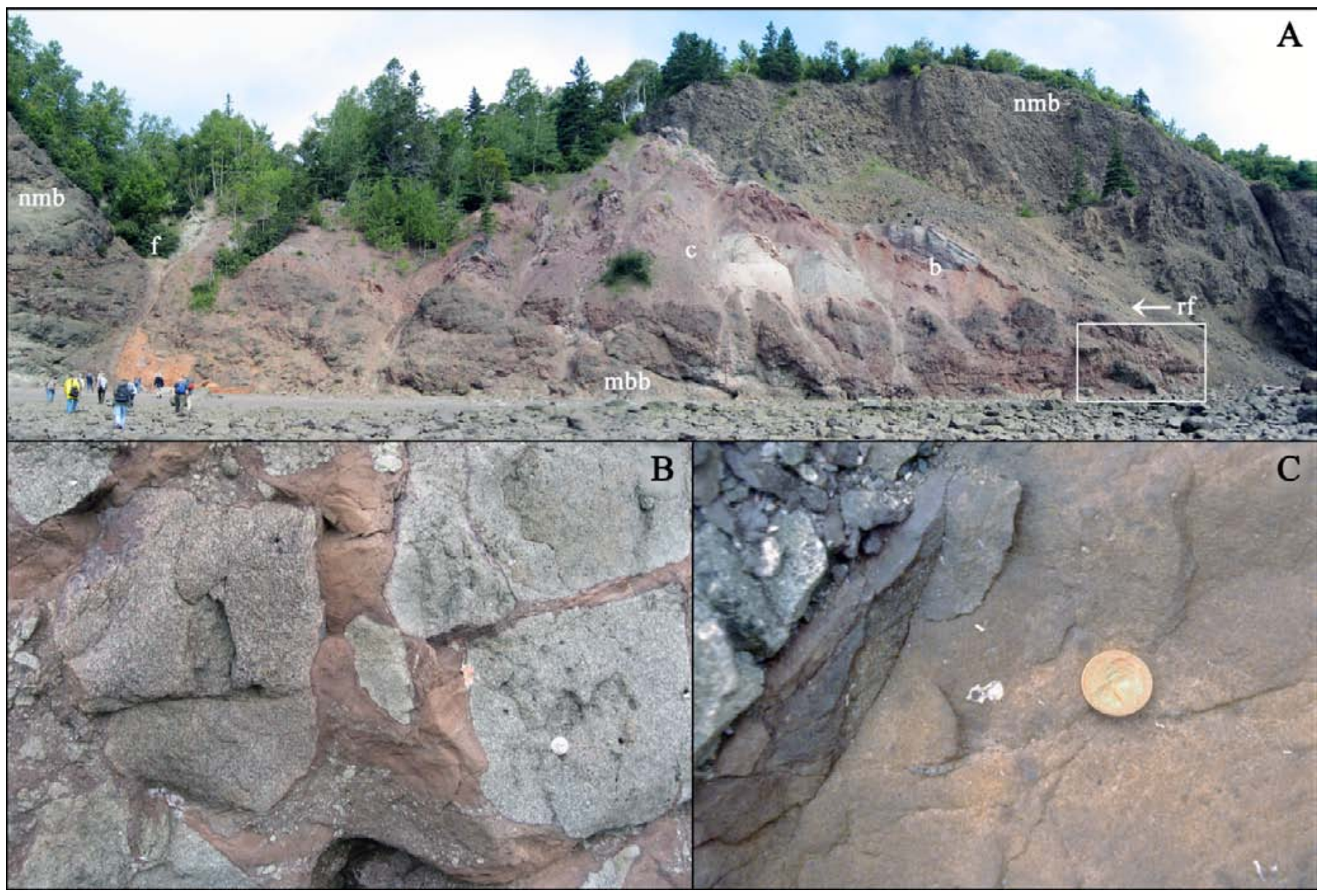

Figure 29. Talus-slope breccia in eastern mini-graben. (A) Panorama looking north at the main outcrops of talus-slope breccia of the McCoy Brook Formation with inset showing most productive area; mbb, talus-slope breccia of North Mountain Basalt clasts in McCoy Brook Formation; b, Partridge Island Member of the Blomidon Formation (brick-red sandstones and conglomerate overlain by grey and variegated sandstone, mudstone, and minor conglomerate) unconformably overlying Carboniferous strata; c, highly deformed Carboniferous clastics and gypsum; f, fault forming western edge of eastern mini-graben; nmb, flows of the North Mountain Basalt; rf, reverse fault in back (north) of breccia. (B) Close-up of breccia showing bedding in the basalt-bearing sandstone between blocks of basalt talus from the easternmost outcrop in (A) (Canadian 25-cent coin is $23.88 \mathrm{~mm}$ in diameter). (C) Close-up of vertebra and other bone fragments in sandy matrix between basalt clasts in breccia from the most productive area within inset in (A) (Canadian one-cent coin is $19.05 \mathrm{~mm}$ in diameter).

postcranial bones originally assigned to ornithischian dinosaurs on their specimen labels, such as vertebral centra (YPM VP 008693a, b) and possible rib fragments (YPM VP 008694, VP 008695), show no features supporting such an identification. The ornithischian teeth represent the oldest definitive skeletal remains of dinosaurs known to date in Canada. Finally the fish-scale-rich mudstone has yielded small, recurved tooth crowns with finely serrated edges. These crowns are referable either to crocodylomorphs or to theropod dinosaurs (Olsen et al. 2005a, fig. 20F).

Overlying the Scots Bay Member are fluviolacustrine red and brown sandstones and mudstones, which are well exposed in the cliffs and on the foreshore (Fig. 28A, localities $\mathrm{b}$ and $\mathrm{c}$ ). These deposits contain abundant dissociated and occasional articulated material of (in order of abundance) the sphenodontian lepidosaur Clevosaurus bairdi (including the holotype, NSM988GF1.1; Fig. 31A), the crocodyliform Protosuchus micmac (Fig. 32A-B), and the cynodont Pachygenelus cf. P. monus (Fig. 33A-B).

Other than protosuchid osteoderms, well-preserved skeletal remains of the sphenodontian lepidosaur Clevosaurus bairdi are the most commonly found tetrapod fossils in the fluviolacustrine strata (Sues et al. 1994). This taxon is represented not only by a number of isolated 


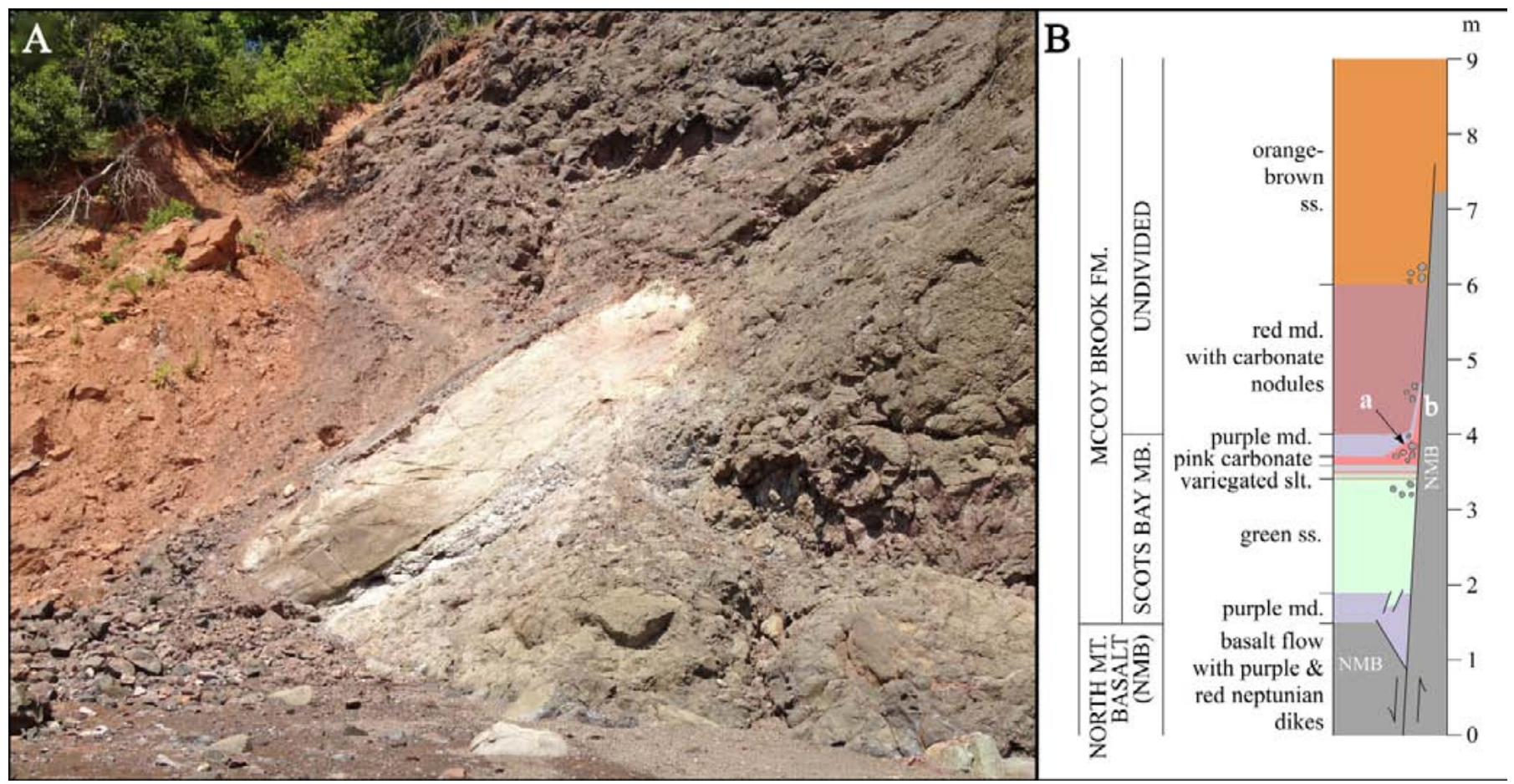

Figure 30. Faulted onlap relationship between the Scots Bay Member of the McCoy Brook Formation and the North Mountain Basalt. (A) Photograph looking north towards outcrop of onlap at $45.393483^{\circ} \mathrm{N}, 64.237833^{\circ} \mathrm{W}$ (locality c in Fig. 28A). (B) Measured section at same location with (a) Scots Bay Member facies producing fossils of tetrapods (McCoy Brook lithologies have basalt clast talus adjacent to fault and Scots Bay units are smeared out on fault plane (b), which is oblique relative to the sedimentary bedding) (measured by PEO on 20 July 2012).

dentaries and maxillae but also two incomplete skulls and two partial skeletons, one of which (FGM996GF050) includes much of the skull (Fig. 31B-C). Referral of the specimens to Clevosaurus is based on the presence of a lateral contact between the ectopterygoid and palatine, which excludes the maxilla from the margin of the suborbital fenestra, and the presence of a long, posteriorly extending dorsal process of the jugal (Sues et al. 1994; Jones 2006). As in other clevosaurs, the snout is proportionately short. Clevosaurus bairdi has more teeth than the Late Triassic type species of Clevosaurus, Clevosaurus hudsoni, from southwestern England (Fraser 1988), and its skull appears relatively more robust. Clevosaurus was widely distributed across Pangaea and ranged from the Late Triassic to the Early Jurassic (Sues et al. 1994; Bonaparte and Sues 2006).

The tritheledontid Pachygenelus cf. $P$. monus is represented by a few incomplete cranial and mandibular elements from the fluviolacustrine strata (Shubin et al. 1991; Fig. 33A-B).

Thick orange-brown aeolian dune sandstones and less common brown interbedded interdune sandstones and red fluviolacustrine mudstones overlie the fluviolacustrine red and brown sandstones (Fig. 28A, locality f). Tetrapod elements are generally rare in these deposits and comprise mostly isolated bones of Clevosaurus; a significant exception is a bone bed with articulated, as well as dissociated, skeletal remains of sauropodomorph dinosaurs preserved with basalt clasts (Fedak 2007) in what is plausibly interpreted as an interdune clastic deposit in close proximity to a fault scarp of basalt.

Locality f has produced several associated sets of skeletal remains of sauropodomorph ('prosauropod') dinosaurs. Following PEO's initial discovery of a cervical vertebra in August 1976, several vertebrae and limb-bone fragments (YPM VPPU 022196) were recovered during two subsequent visits by teams from Princeton University led by Don Baird (Fig. 34). Ken Adams, former Curator of the Fundy Geological Museum, and George Hrynewich later collected much of another postcranial skeleton (FGM994GF69). This specimen is smaller (femur length less than $30 \mathrm{~cm}$ ) than the original find (estimated femur length about $45 \mathrm{~cm}$ ). Further work by Tim Fedak at this site in 1997 led to the discovery of a third partial skeleton (FGM998GF9; femur length about $50 \mathrm{~cm}$ ) from the Princeton quarry. Further excavations recovered a left complete femur, tibia, and fibula, the distal end of a right femur, several vertebrae, a nearly complete ischium, and several bones of the forelimbs. In 1998, a large, articulated specimen was discovered (FGM998GF13_I). 


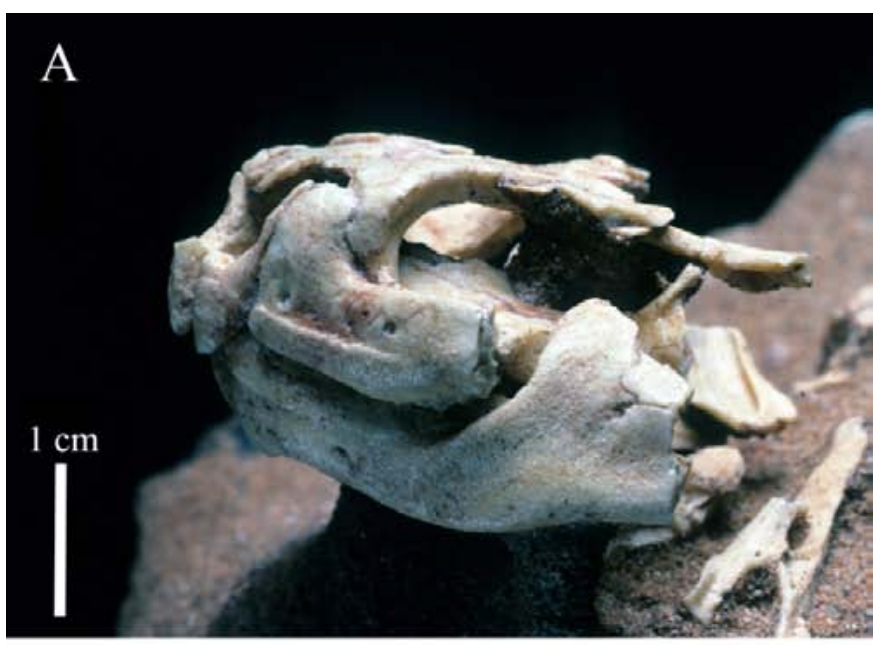

B
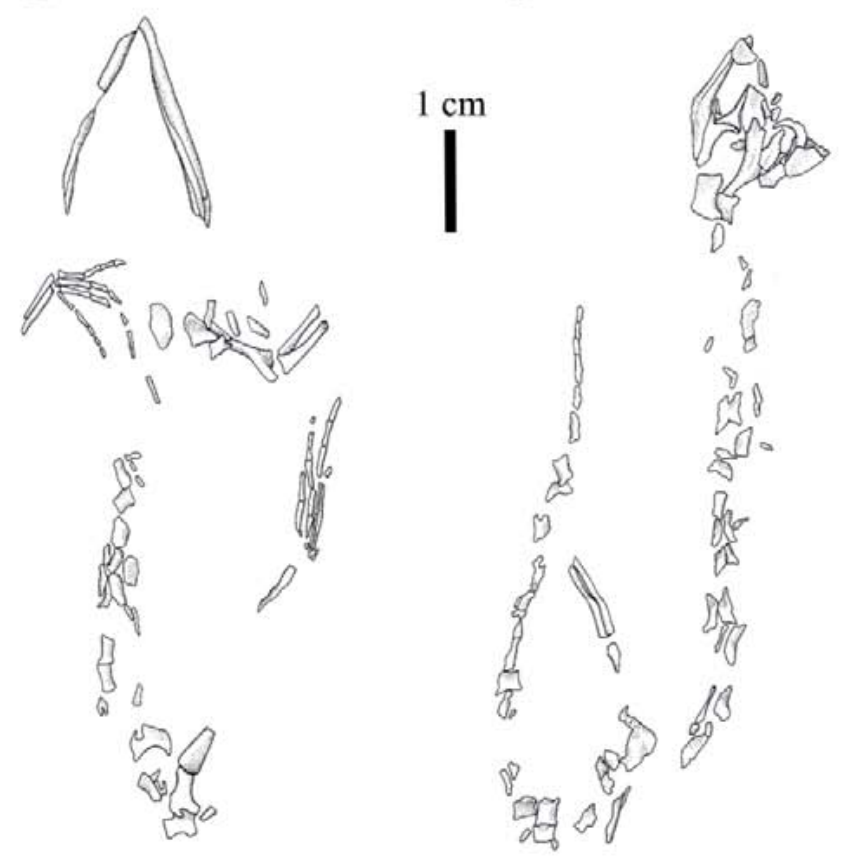

C

Figure 31. Clevosaurus bairdi from the McCoy Brook Formation at Wasson Bluff. (A) Partial skull in oblique left lateral view (NSM988GF1.1, holotype). (B-C) Incomplete skull and skeleton (FGM996GF050) in (B) ventral and (C) dorsal views.

During subsequent excavations to recover this material, two additional sets of skeletal remains (FGM998GF13_II and FGM998GF13_III) were found, including much of a dissociated skull. This material has yet to be published in detail. The specimens have previously been cited as cf. Ammosaurus sp. (Shubin et al. 1994). However, their affinities remain uncertain because many of the bones were affected, often severely, by tectonic deformation, and perhaps more than one taxon is represented.

One partial, badly deformed and fragmentary skeleton (NSM005GF009 and FGM998GF46; Fedak 2007), probably a sauropodomorph, was found below the talus-slope breccia on the western side of the middle mini-graben (Fig. 28A, locality g). This specimen is important because it preserves gastroliths (Whittle and Onorato 2000; Fedak 2007). The stones themselves can be identified as gastroliths not only because of their position inside the ribs and gastralia fragments, but more importantly because they comprise mostly rounded quartz clasts, a lithology otherwise completely absent from the McCoy Brook Formation in the Wasson Bluff region. Therefore, transport to the fossil site in the gastric mill of the dinosaur from another region seems the only reasonable explanation for their occurrence. This find provides further evidence that at least some sauropodomorphs apparently used a gastric mill (cf. Wings 2005). The apparent absence of similar gastroliths in other sauropodomoph specimens from Wasson Bluff may reflect postmortem loss or basalt gastroliths that have gone unnoticed due to the abundance of other basalt clasts in the matrix. In addition, a mandibular ramus of Clevosaurus was found associated with the gastroliths (PEO, personal observation), which led Barrett (2000) to argue that 'prosauropods' were omnivorous. Possible alternative explanations are that the small reptile bone was deliberately ingested for nutrients (Esque and Peters 1994; White 2011), or that the bone was accidentally associated with the dinosaurian remains (Fedak 2007).

The youngest strata in the middle mini-graben are exposed at low tide in the foreshore (Fig. 28A, locality e) and consist of tabular sandstone beds, which have yielded small brontozoid footprints (Anchisauripus sensu Lull 1953). These tracks unfortunately disintegrated before they reached a repository (Fig. 35).

The western mini-graben contains yet another distinctive sequence (Fig. 28A, locality h), which is difficult to correlate with that in the middle mini-graben except that the section includes the Scots Bay Member at its base (Fig. 36A). The only tetrapod material recovered from this area to date is a small block of purplish calcareous mudstone preserving a patch of abdominal dermal armour probably referable to Protosuchus (FMG007GF1) and found by Gustaf Olsen in 2007 (Fig. 36B). The matrix closely resembles the calcareous stringers found in palaeosols interbedded with the basalt debris flows.

McKay Head. Outcrops between the North Mountain Basalt headland of McKay Head and Wasson Bluff (Fig. 36) have yielded an important footprint assemblage from the foreshore of the type-section of the McCoy Brook Formation. PEO discovered the first tracks in 1978. Subsequently, PEO, his associates, and the collector Eldon 

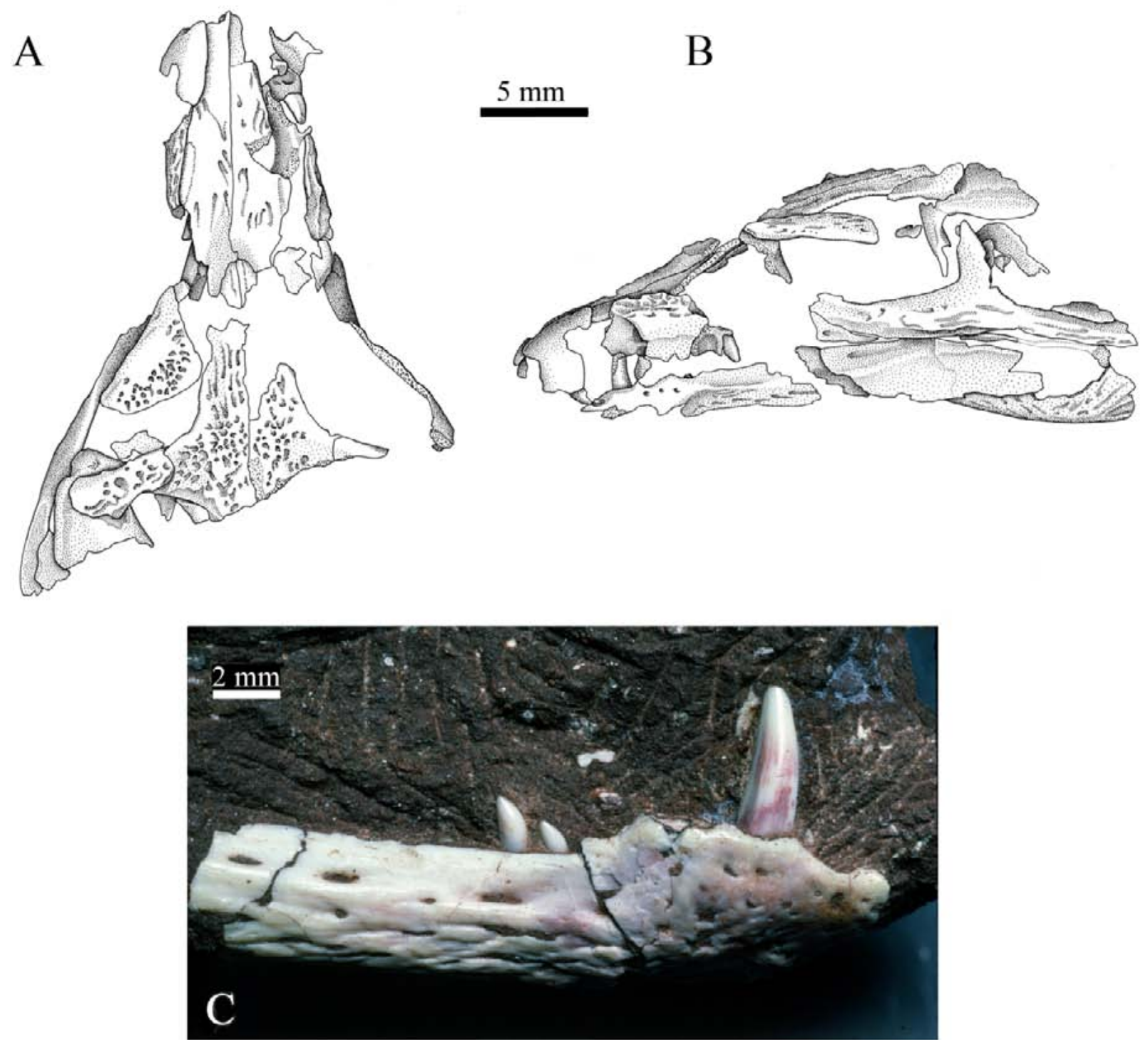

Figure 32. Protosuchus micmac from the McCoy Brook Formation at Wasson Bluff. (A-B) Partial skull (FGM999GF64) in (A) dorsal and (B) left lateral views. (C) Right dentary (NSM988GF7.1, holotype) in lateral view.

George from Parrsboro have collected significant additional material. The deposits appear to represent fluvial crevasse splays, although a marginal lacustrine setting cannot be ruled out. The footprints are recovered only as natural casts (positive hyporelief) in sandstone because the impressions in mudstone disintegrate during the collecting process.

Crocodylomorphs are represented by abundant small to large tracks of Batrachopus, the trackmaker attribution being closely similar to that of Batrachopus deweyii and Batrachopus dispar (Olsen and Padian 1986) (Fig. 37C). Theropod dinosaurs produced small (e.g., YPM VP 008668, YPM VPPU 23631) to minute brontozoid tracks (Anchisauripus and Grallator in the classification by Lull
1953). The media have touted the smallest specimen (also on slab YPM VPPU 023631; Fig. 37D) as the smallest known dinosaur footprint in the world, but tracks of comparable size are also known from other Newark Supergroup deposits (Olsen 1995b; Olsen et al. 1998). Numerous tracks of Anomoepus scambus document the presence of ornithischian dinosaurs (Olsen and Rainforth 2003; Figs. 37H, 38A). Particularly noteworthy is the relative abundance of the ichnotaxon Otozoum moodii, which has been plausibly attributed to sauropodomorphs (Rainforth 2003) and some of which are beautifully preserved. Eldon George donated a particular noteworthy partial trackway of Otozoum to the Nova Scotia Museum of Natural History 


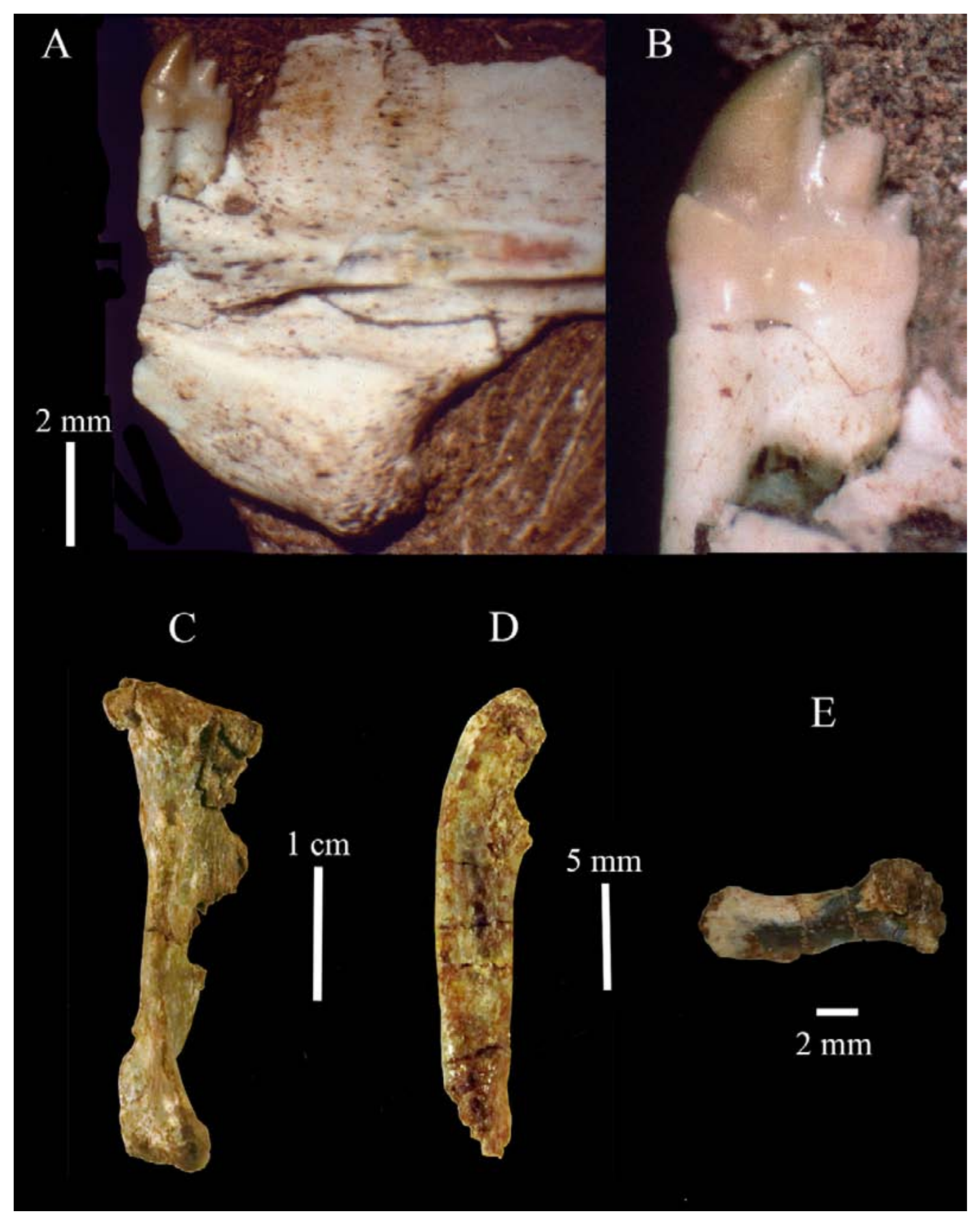

Figure 33. Cynodonts from the McCoy Brook Formation at Wasson Bluff. (A) Posterior portion of right dentary of Pachygenelus cf. P. monus (MCZ 9139) with posterior postcanine tooth in medial (lingual) view. (B) Enlarged view of the posterior postcanine tooth in (A). (C) Right humerus of tritylodontid (NSM014GF014.002) in dorsal view. (E) Incomplete right ulna of cynodont (NSM014GF014.003) in lateral view. (F) Partial right ischium of cynodont (NSM014GF014.007) in lateral view.

(Grantham 1996). The absence as yet of large brontozoid tracks such as Eubrontes is striking.

Blue Sac west. Cliff and foreshore outcrops between Blue Sac Road and Moose River have yielded a few protosuchid osteoderms from talus-slope breccias and a significant footprint assemblage from fluviolacustrine strata (Fig. 37). Outcrops of basalt talus-slope breccias of the McCoy Brook Formation occur at the more eastern outcrops 


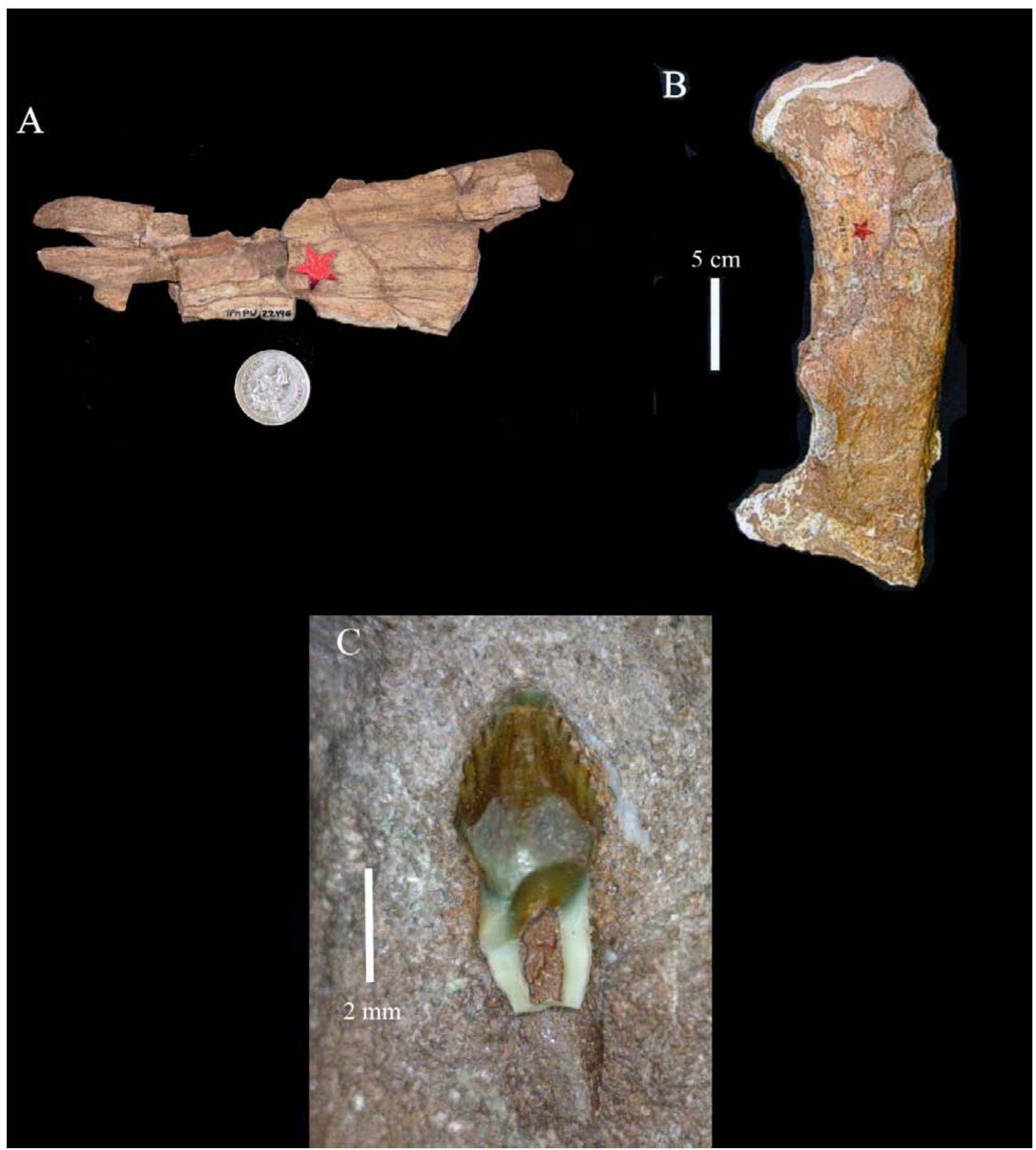

Figure 34. (A-B) Bones of the first sauropodomorph skeleton (YPM VPPU 022196) recovered from the McCoy Brook Formation at Wasson Bluff in 1976. (A) Incomplete cervical vertebra in left lateral view (Canadian 25-cent coin is 23.88 $\mathrm{mm}$ in diameter). (B) Proximal portion of femur. (C) Ornithischian tooth crown with attached partial root (and impression of root) (NSM014GF014.001).

and have yielded the osteoderms (rediscovered on 2 July 2014 at $\left.45.401530^{\circ} \mathrm{N}, 64.135475^{\circ} \mathrm{W}\right)$. These breccias do not occur in proximity to any known actual basalt flow outcrops, the palaeocliffs of which were presumably lifted to a higher structural level and subsequently eroded. More westerly outcropping strata presumably occur at a higher 


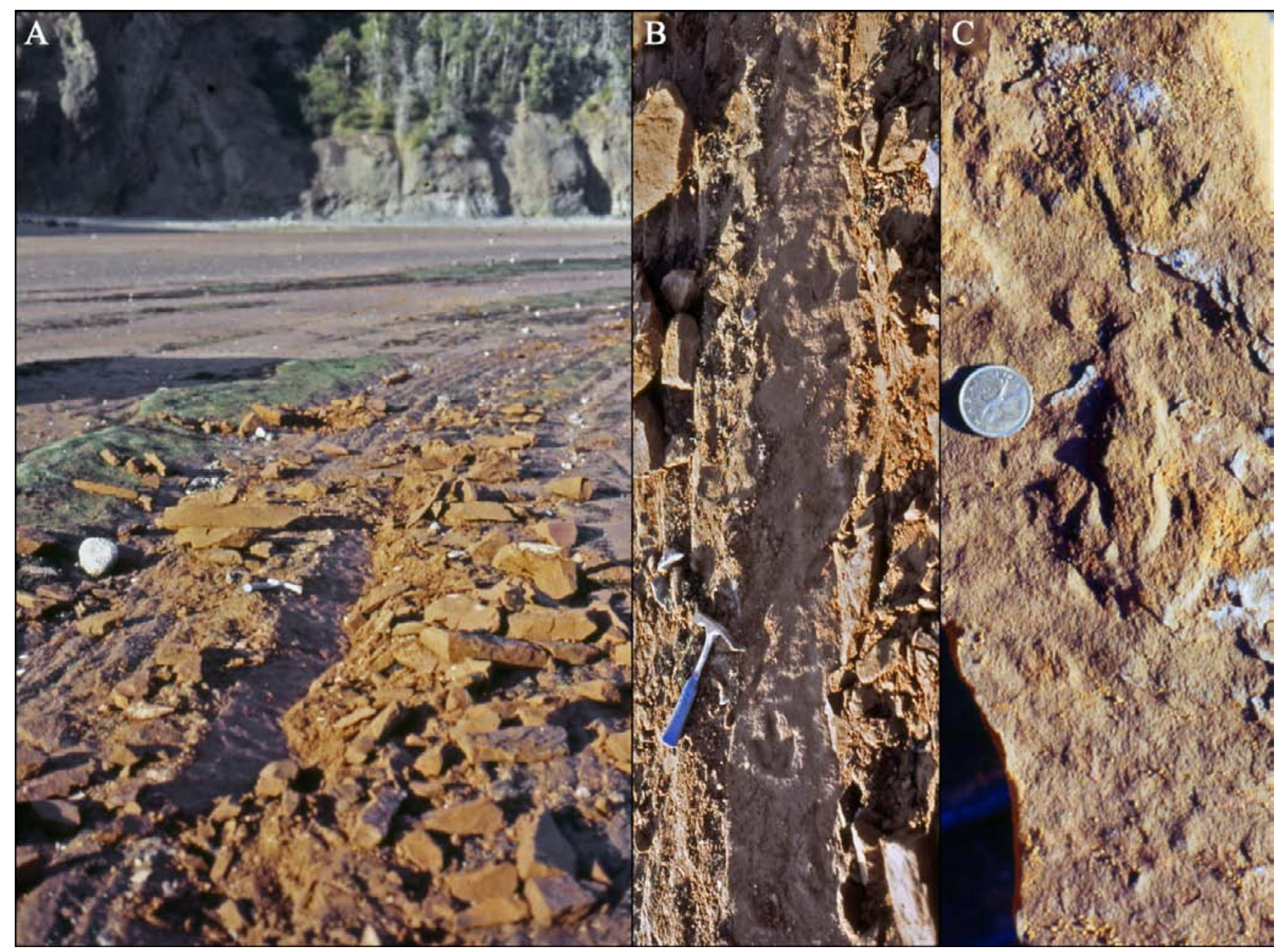

Figure 35. Brontozoid (cf. Anchisauripus) trackway excavated in the foreshore in the middle mini-graben at Wasson Bluff in September 1987 (locality e in Fig. 25A, C-D). (A) View of excavation towards east, along strike at low tide. (B) Trackway (length of hammer: $27.9 \mathrm{~cm}$ ). (C) Natural cast of uppermost track in (B). (Canadian 25-cent coin is $23.88 \mathrm{~mm}$ in diameter.)

stratigraphic level than the breccia and closely resemble deposits of the type McCoy Brook Formation and yield well-preserved footprints, the first of which were discovered by PEO in 1978. Small brontozoid tracks (Anchisauripus) have been found along with relatively common footprints of Anomoepus scambus (YPM VP 008665, FGM994GF2; Olsen and Rainforth 2003; Fig. 38A, C) and poorly preserved tracks of Otozoum (YPM VP 008669; Fig. 38B).

Blue Sac east. Beach cliff outcrops east and north east of Blue Sac Road have yielded only tracks of Otozoum from volcanoclastic sandstones in rock falls (Fig. 39). This ichnotaxon is usually so uncommon that this occurrence deserves special mention.

Five Islands Provincial Park. Extensive outcrops of McCoy Brook Formation occur in large cliffs and along the foreshore to the west of The Old Wife in Five Islands
Provincial Park. Originally these outcrops were thought to represent part of the Blomidon Formation, but on structural grounds Liew (1976) correctly reinterpreted them as lying above the North Mountain Basalt rather than below it. This conclusion corresponds with PEO's 1973 observation that the succession preserves a footprint assemblage similar to one from the Hartford basin and first discovered by PEO and Baird in 1973 (Baird MS, pp. 531-532). Although strata west of The Old Wife are now accepted as part of the McCoy Brook Formation, their precise level within the formation is not clear. Although a contact with the North Mountain Basalt is exposed within the cliff face, the contact is structurally complex and condensed. Structural continuity between the main cliff outcrop of gently dipping strata and the basalt is not evident, but it appears that the McCoy Brook strata may lie far above the basalt contact, plausibly making them the 


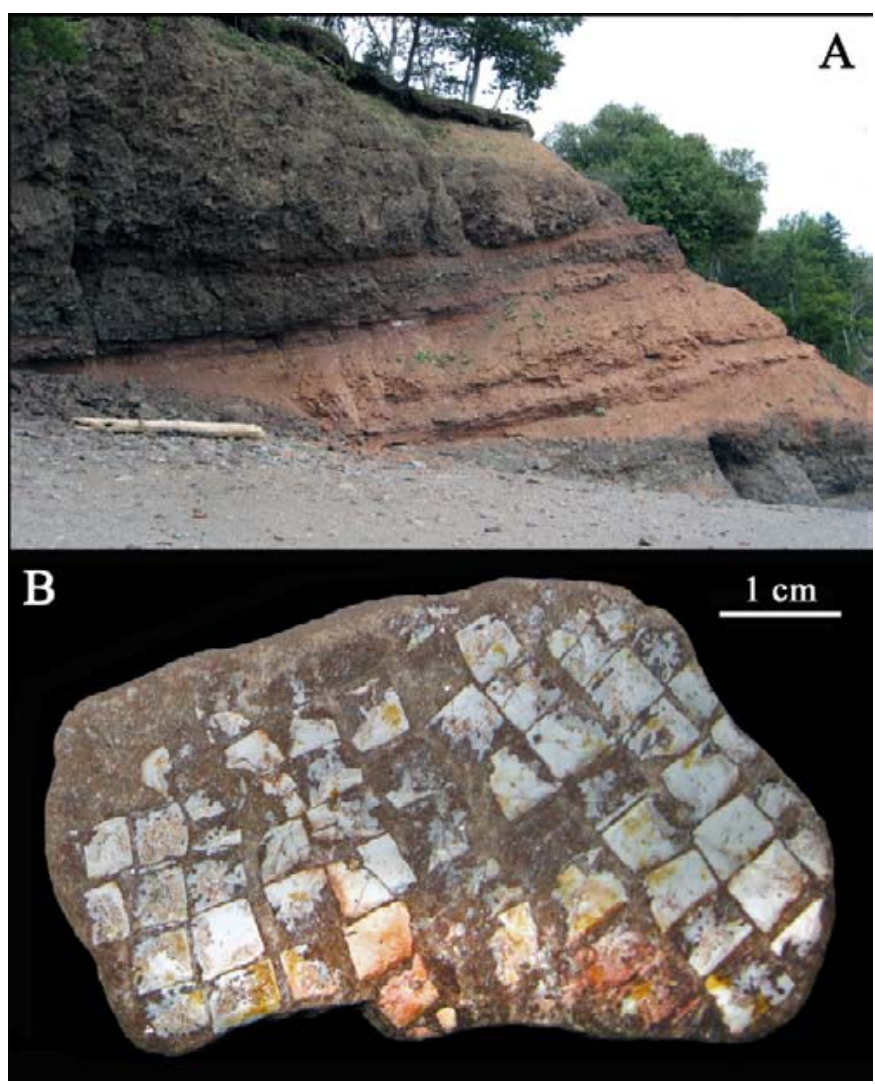

Figure 36. (A) Lower mudstone and sandstone palaeosol interbed between basalt-clast debris flows in western mini-graben debris flows. (B) Portion of protosuchid abdominal armour (FMG007GF1) found in float adjacent to basalt debris flows in western mini-graben debris flows (location h in Fig. 24).

stratigraphically highest and youngest exposed units within the Fundy basin.

Although no definitive tetrapod skeletal remains have been recovered from Five Islands Provincial Park, an important assemblage of footprints has been assembled over the years (Fig. 40). This assemblage differs from those at McKay Head and Blue Sac east and west in being dominated by brontozoid tracks of all sizes, including Eubrontes giganteus (Fig. 40C) and apparently lacking Anomoepus and Otozoum.

Coves on the South Shore of Scots Bay. The largely grey, green and brown limestone, silicified limestone, and sandstone beds of the type Scots Bay Member have yielded a few tetrapod bones and a slightly richer assemblage of footprints (Fig. 41). To date several sphenodontian bones have been reported (Cameron and Jones 1988), as well as small and large brontozoid tracks (Fig. 41B-E). The assemblage is consistent with, but much less rich than, that at Wasson Bluff.
The tetrapod assemblage from the McCoy Brook Formation closely resembles presumably more or less coeval, post-end-Triassic-extinction assemblages from China, Europe, southern Africa and the American Southwest (Sues et al. 1994). With the possible exception of the sauropodomorph dinosaur, all identifiable tetrapod genera are shared by at least one of these other assemblages.

\section{DISCUSSION}

In addition to the fact that several specific faunal elements add considerably to our knowledge of the diversity, palaeobiology and phylogenetic relationships of early Mesozoic continental tetrapods, the faunal assemblages from the Fundy basin are noteworthy in three major respects. First, they contain the only currently known example of tightly temporally constrained latest Rhaetian and earliest Hettangian assemblages of continental tetrapods with associated radiometric ages anywhere. Second, they comprise one of only two sequences of fully continental tetrapod assemblages spanning the Middle Triassic through Early Jurassic (the other being in the American Southwest). Finally, they currently represent the highest-palaeolatitude occurrences of early Mesozoic continental tetrapods in North America. Each tetrapod assemblage provides important and unique insights into the patterns and processes of faunal change and geographic provinciality in continental ecosystems during the first third of the Mesozoic Era.

\section{Evidence for the end-Triassic extinction (ETE)}

The faunal assemblages from the McCoy Brook Formation shed light on the timing and pattern of faunal change at the ETE, with much detail having accrued since the original assessment by Olsen et al. (1987). With the establishment of the GSSP (Global Boundary Stratotype Section and Point) of the base of the Hettangian, and hence the Triassic-Jurassic boundary (Hillebrandt et al. 2007, 2013), the issue of the extinction event has become separated from the recognition of the system boundary. The GSSP for the base of the Hettangian is now defined as the first appearance of the ammonite Psiloceras spelae tirolicum (Hillebrandt and Krystyn 2009) at the Kuhjoch section in the Karwendel Mountains of the Northern Calcareous Alps in Tyrol (Austria). Consequently, recognition of the ETE in the Fundy basin is not the same as identification of the Triassic-Jurassic boundary, an issue that has tended to muddle past discussions of relevant data from the Fundy basin and elsewhere. However, keeping in mind the distinction between these issues, the Fundy assemblages provide a critical datum for the faunal ETE. 


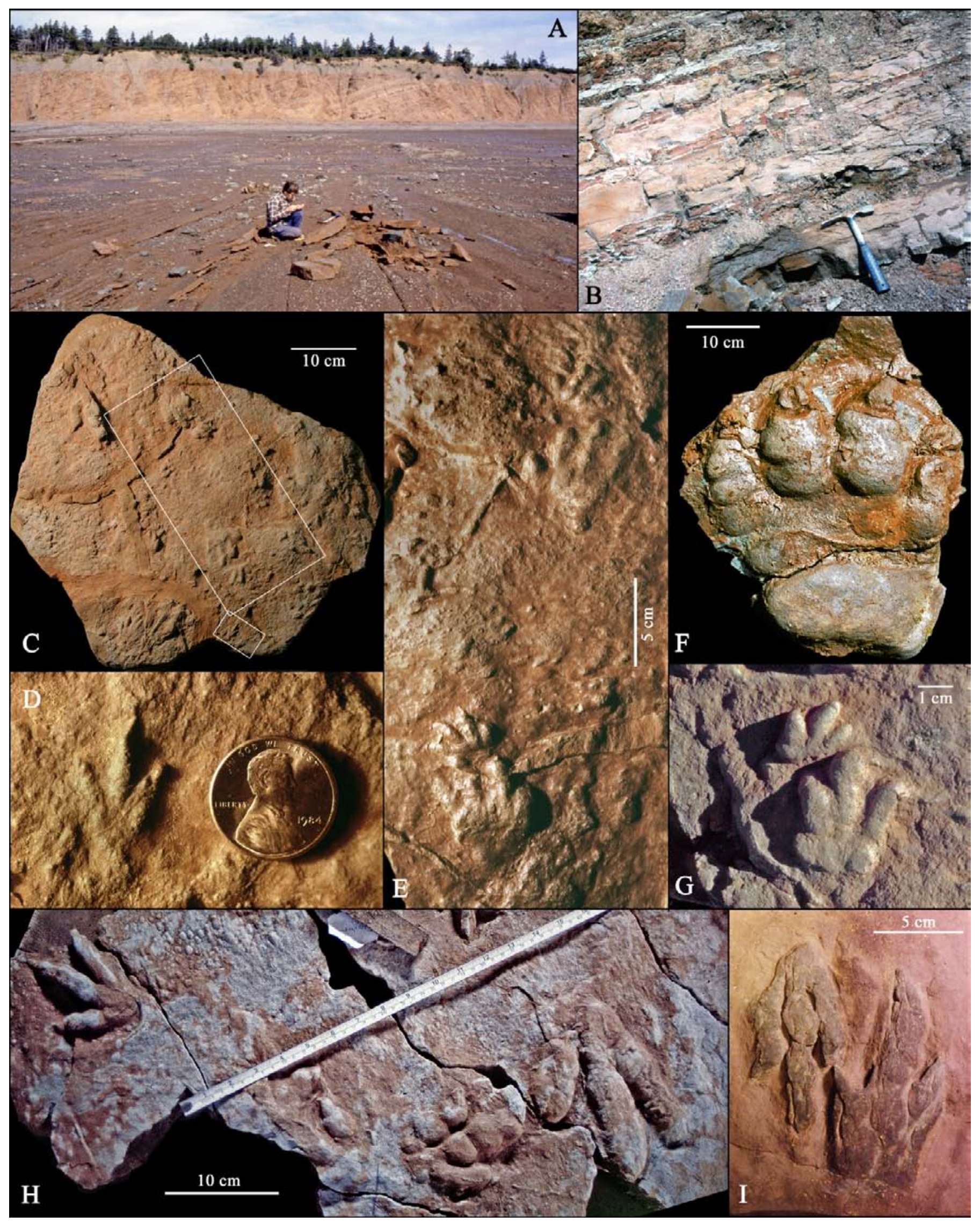


Figure 37. (previous page) Tetrapod footprints from the type section of the McCoy Brook Formation at McKay Head (locality 15 in Fig. 2E; Tanner 1996). (A) PEO collecting tracks in the foreshore at low tide, view is to north at approximately $45.393^{\circ} \mathrm{N}, 64.215^{\circ} \mathrm{W}$ (photo by Amy McCune, 3 November 1980). (B) Characteristic track-bearing interbeds of tabular brown sandstone beds overlying friable red mudstones; bed producing Otozoum in (F) is at about $45.3961^{\circ} \mathrm{N}, 64.2104^{\circ} \mathrm{W}$ (section B of Tanner 1996). (C) YPM VPPU 023631, slab bearing numerous ichnites, mostly indistinct Batrachopus spp., but including one right-left pair of manus pes sets of Batrachopus cf. B. dispar (large Batrachopus), large inset box enlarged in E, one right pes impression of a small brontozoid (cf. Grallator), and one very small brontozoid (cf. Grallator or Stenonyx) in small inset box, enlarged in D. (D) Very small brontozoid (cf. Grallator or Stenonyx) footprint on slab YPM VPPU 023631, touted as "world's smallest dinosaur footprint" by Time magazine (17 November 1986) (photo by the late Donald Baird). (E) Batrachopus cf. B. dispar on YPM VPPU 023631, large inset box in (C) (photo by the late Donald Baird). (F) Otozoum moodii (FMG998GF53), natural cast of right pes, slightly compressed anteroposteriorly. (G) Batrachopus deweyi, natural cast of left manus-pes set (Eldon George collection, Parrsboro). (H) Upper left and lower right: Anomoepus scambus. Lower centre: brontozoid (cf. Anchisauripus) (all tracks distorted) (Eldon George collection, Parrsboro). (I) Plaster cast (YPM VP 008668) of natural cast of right and left pedes of different individuals of brontozoid tracks (cf. Anchisauripus sillimani).

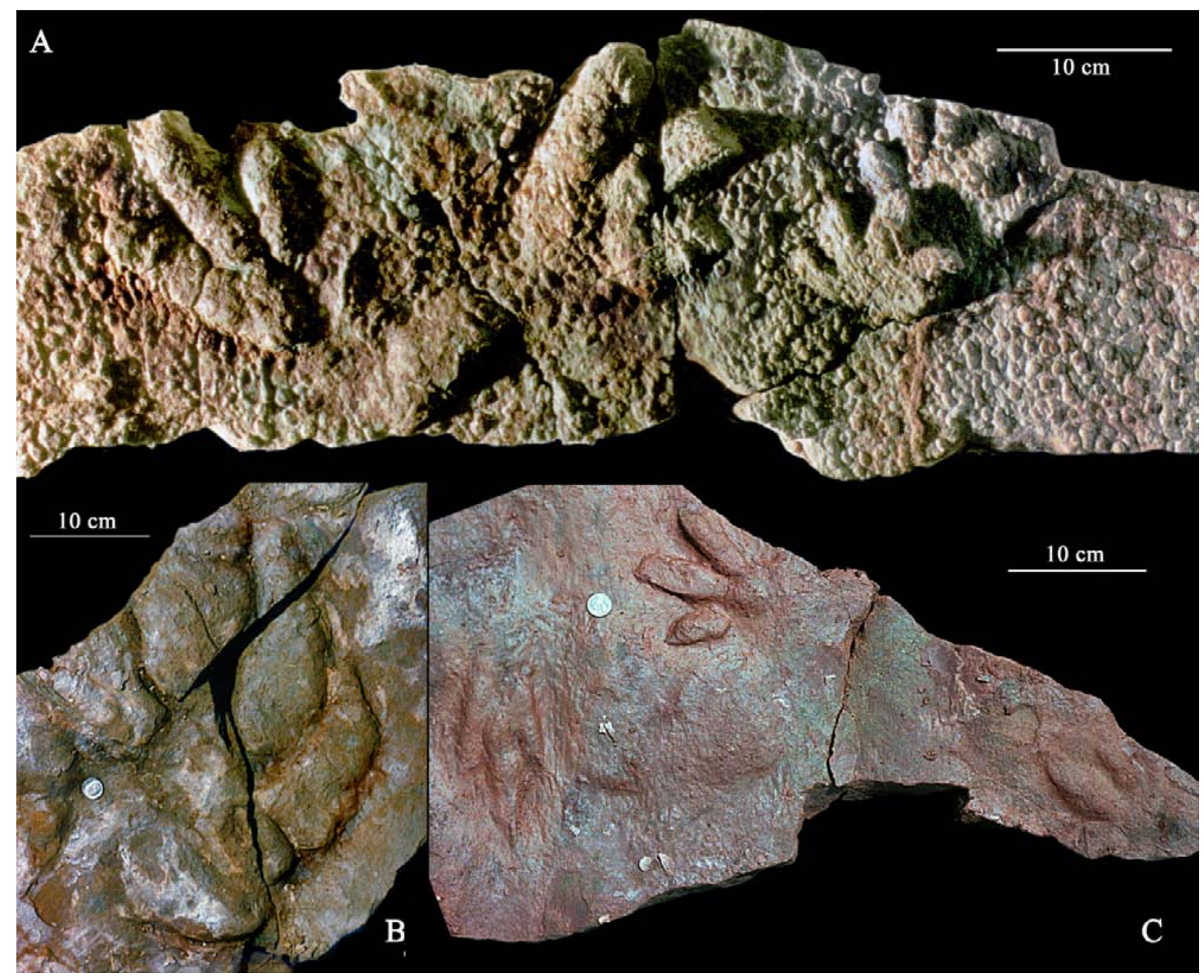

Figure 38. Natural casts of tetrapod footprints from Blue Sac west (locality 14 in Fig. 2E). (A) Large footprints of Anomoepus scambus in two trails (FGM994GF2), comprising a pes imprint with a metatarsal impression and an associated doublestruck manus impressions of one trail and an isolated pes imprint of a second trail. (B) Fragmented and distorted right pes of Otozoum moodii. Not collected. (C) Successive right-left pes impressions of Anomoepus scambus and isolated left brontozoid (cf. Anchisauripus) pes impression (YPM VP 008665). 

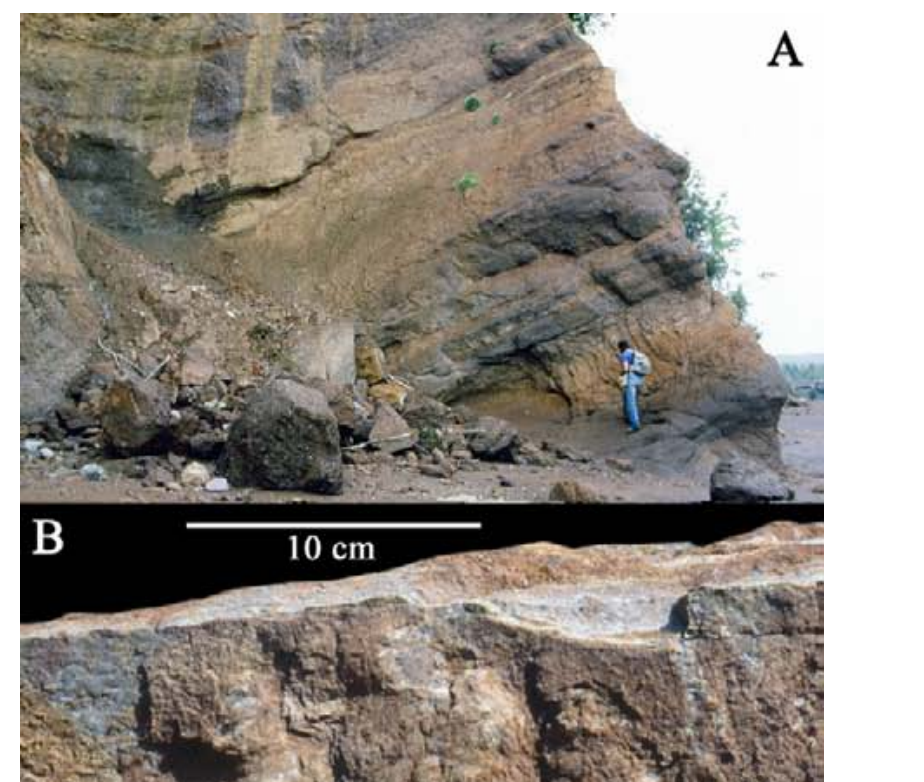

Figure 39. Otozoum from Blue Sac east (locality 12 in Fig. 2E). (A) Outcrop of track-bearing interbedded basaltic conglomerate and brown volcanoclastic sandstone with Joe Smoot for scale; taken in $1984\left(45.4051^{\circ} \mathrm{N}, 64.1111^{\circ} \mathrm{W}\right)$. (B) Otozoum moodii, natural cast of left pes impression, not collected. (C) Otozoum moodii, natural cast of small left pes and metatarsus impression, not collected (length of hammer: $29.2 \mathrm{~cm}$ ).

Fowell and Traverse (1995) and Cirilli et al. (2009) showed that the initial palynological expression of the ETE occurs in the Partridge Island Member of the Blomidon Formation above the palaeomagnetic polarity chron E23r. This is consistent with the picture in the Newark basin where it coincides with a major turnover among tetrapod ichnotaxa (Olsen et al. 2002; Whiteside et al. 2007; Olsen et al. 2011; Blackburn et al. 2013). However, Cirilli et al. (2009) documented the presence of a few taxa of pollen and spores characteristic of the latest Rhaetian in Europe in the basal portion of the Scots Bay Member. This is consistent with the projected correlation of the GSSP of the base of Hettangian stage to a level above the North Mountain Basalt (Whiteside et al. 2010; Blackburn et al. 2013; Fig. 5).

Blackburn et al. (2013) calculated the age of the ETE as $201.564 \pm 0.015 \mathrm{Ma}$, based on eight zircon CA-TIMS ${ }^{206} \mathrm{~Pb} /{ }^{238} \mathrm{U}$ ages from eastern North American and Moroccan CAMP igneous rocks, including a 201.566 $\pm 0.031 \mathrm{Ma}$ date from the North Mountain Basalt. Based on these dates, the age of the Triassic-Jurassic boundary should be about $100 \pm 40 \mathrm{ka}$ after the ETE, or $201.42 \pm 0.02 \mathrm{Ma}$ (RMS error) (where the larger uncertainty derives from problems with correlating the marine and terrestrial astrochronologies). These ages are consistent with lower-precision and entirely independent $\mathrm{U}-\mathrm{Pb}$ dates from marine sections (Guex et al. 2012; Wotzlaw et al. 2014). Based on cyclostratigraphic correlation of the Scots Bay Member to the more southern Hartford and Newark basin sections, the Triassic-Jurassic boundary projects to above the top of the Scots Bay Member (Whiteside et al. 2010; Blackburn et al. 2013). Thus, the fluviolacustrine sandstone assemblage, the Scots Bay vertebrate assemblages (at Scots Bay and Wasson Bluff), and the pre-Scots Bay assemblage (Wasson Bluff) are latest Triassic (latest Rhaetian) in age, as are the North Mountain Basalt and the Partridge Island Member of the Blomidon Formation. However, these later assemblages, as well as the top of the Partridge Island Member, postdate the initial phase of the ETE, with floral changes evidently continuing through the remainder of the Rhaetian. The post-Scots Bay tetrapod assemblage with sauropodomorph dinosaurs at Wasson Bluff is plausibly earliest Hettangian in age, and the other McCoy Brook assemblages are of even younger, presumably Hettangian age.

Thus the assemblages from the McCoy Brook Formation are critically important to the discussion of the end-Triassic extinction among continental tetrapods because they can 


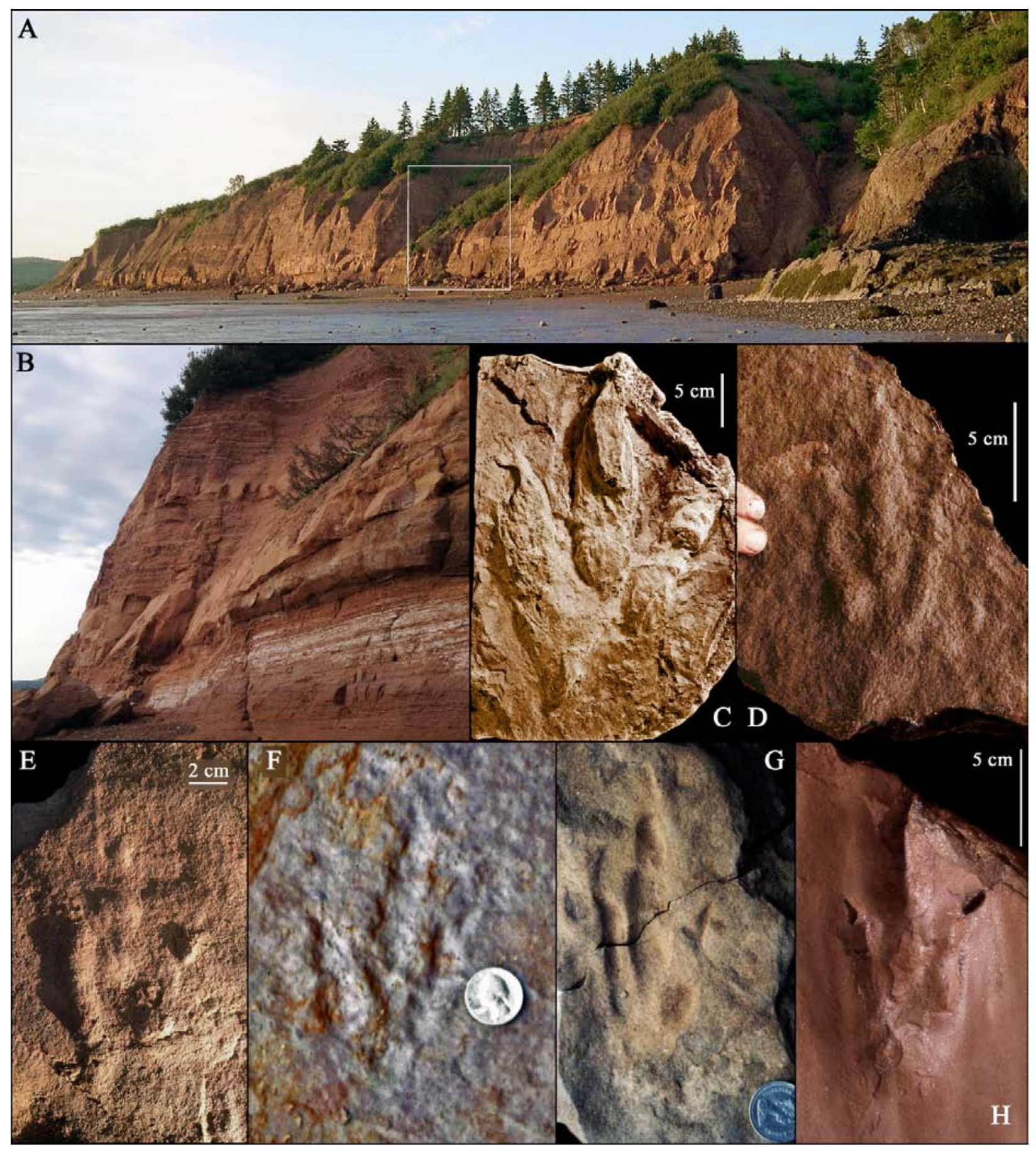

Figure 40. Tetrapod footprint assemblage from the McCoy Brook Formation of Five Islands. (A) Gently dipping strata of the formation, view towards northwest: the North Mountain Basalt on right underlies the McCoy Brook Formation with a faulted onlap; the main footprint-bearing units are relatively low in the section, below a prominent laterally continuous set of sandstone beds (inset locates the close-up in B), but footprints do occur higher elsewhere in the section. (B) Detail of tabular, laterally persistent sandstone and mudstone layers parsimoniously interpreted as marginal lacustrine or very shallow lacustrine strata (low in photo), producing abundant brontozoid footprints. (C) Eubrontes cf. E. giganteus, plaster cast of right pes impression. (D) Natural cast of brontozoid (cf. Anchisauripus) left pes impression (YPM VP 007353). (E) Natural cast of brontozoid (cf. Anchisauripus) right pes impression (NSM014GF023.001). (F) Brontozoid (cf. Anchisauripus) left pes impression, not collected (US 25-cent coin is $24.26 \mathrm{~mm}$ in diameter). (G) Brontozoid (cf. Anchisauripus) left pes impression (YPM VP 007354) (Canadian 25-cent coin is $23.88 \mathrm{~mm}$ in diameter). (H) Small brontozoid (cf. Grallator cursorius) (YPM VP 008708). 





Figure 41. (previous page) Tetrapod footprints from the Scots Bay Member, Scots Bay area. (A) Outcrop face is about $5 \mathrm{~m}$ high; large fallen block in lower centre is sandstone bearing the footprint shown in B facing towards outcrop; lower arrow marks contact between North Mountain Basalt and overlying carbonates of the Scots Bay Member of the McCoy Brook Formation; middle arrow marks contact between the carbonates of the Scots Bay Member and sandstones that can be interpreted as McCoy Brook Formation, undivided or upper Scots Bay Member (there are abundant clasts of the typical strata of the Scots Bay Member in the cross-bedded sandstone; upper arrow marks the upper surface of the cross-bedded sandstone bearing abundant footprints such as those shown in B and C. Above this are more thinly bedded sandstones (photo taken from $45.2514^{\circ} \mathrm{N}, 64.4450^{\circ} \mathrm{W}$, middle outcrops at Hassan's (2000) Central Broad Cove; photo taken on 31 August 2012). (B) Brontozoid footprints. The one at left is a large specimen of Eubrontes giganteus, and in the middle of the photograph are two medium-sized footprints of cf. Anchisauripus). The footprints are on a large sandstone block derived from the far right edge of $\mathrm{A}$, photographed in 1980 and not collected, now obliterated by erosion (photograph taken just after rain; length of hammerhead: $18.4 \mathrm{~cm}$ ). (C) Medium-sized brontozoid track (cf. Anchisauripus) in sandstone with red mudstone parting filling track (middle digit is approximately $1.2 \mathrm{~cm}$ wide) from block noted in (A) (not collected). (D) Natural cast of poorly preserved medium-sized brontozoid footprint (cf. Anchisauripus) on fallen block of calcareous purple sandstone from Hassan's (2000) Davidson Cove, approximately $45.2686^{\circ} \mathrm{N}, 64.4125^{\circ} \mathrm{W}$ (not collected). (E) Natural cast of very poorly preserved small brontozoid footprint (cf. Grallator) on a fallen block of calcareous purple sandstone, same locality as (D) (not collected). (F) Natural cast in fine calcarenite of a poorly preserved manus-pes set of ?Batrachopus sp. (NSM), eastern part of Hassan's (2000) Central Broad Cove, approximately $45.2515^{\circ} \mathrm{N}, 64.4445^{\circ} \mathrm{W}$.

now be placed in a tight temporal framework. Representing a broad range of depositional environments, ranging from perennial lacustrine to fluvial and aeolian settings, and documented by hundreds of fossils, these assemblages lack any of the characteristic Late Triassic faunal elements, most conspicuously metoposaurid temnospondyls, phytosaurs, procolophonids, and diverse non-crocodylomorph and non-dinosaurian archosaurs, all of which are known from older assemblages in the Fundy basin and elsewhere. The absence of these typical Late Triassic tetrapods is fully consistent with what is seen in other eastern North American sequences that are correlated to the Fundy sections by independent, non-biostratigraphic means. Thus, at least within eastern North America, the tetrapod extinctions characterizing the ETE occurred in less than $100 \mathrm{ka}$ of the initial palynological transition, probably less than $30 \mathrm{ka}$ as seen in the McCoy Brook assemblages. The post-Scots Bay assemblages likewise represent the initial post-ETE Jurassic recovery. Although the initiation of the CAMP is apparently coincident with the initial ETE, and its likely cause (Blackburn et al. 2013), further eruptions of the CAMP post-dating the tetrapod localities at Wasson Bluff seem to have had little or no additional impact on tetrapod diversity. Although taxonomically closely similar assemblages of continental tetrapods are known from the American Southwest, western Europe, southern Africa, and China, none of these other assemblages associated with the Triassic-Jurassic transition has temporal controls anywhere near the level of those for the McCoy Brook assemblages.

\section{Faunal change through the Triassic in time and space}

The stratigraphic continuity and the attendant superposition of tetrapod assemblages through the Fundy
Group section afford an unusually complete perspective on faunal change, albeit at varying levels of precision, and at the highest palaeolatitudinal position exposed in eastern North America. As we examine the various assemblages from the Fundy basin progressively further distant in time from the ETE and the Triassic-Jurassic boundary, in both directions, temporal controls become less precise. Above the Triassic-Jurassic boundary, especially for the McCoy Brook occurrences younger than those at Wasson Bluff, non-biostratigraphic control is entirely lacking. Below the ETE, the White Water and Red Head members of the Blomidon Formation are correlated to the Newark basin astrochronology via palaeomagnetic polarity stratigraphy (Kent and Olsen 2000), which provides a temporal resolution of less than one million years and a substage-level of correlation to marine sections for the Norian and Rhaetian; but this is not true of the important St Mary's Bay assemblage of tetrapod tracks, which has not yet been directly tied to the polarity sequence. The Evangeline Member of the Wolfville Formation can only be dated at the stage level (Carnian) and the age of the Economy Member is even less constrained, although plausibly Middle Triassic based on superposition and tenuous biostratigraphic data. Nonetheless, compared to tetrapod assemblages elsewhere, the present data at least allow correlation to assemblages worldwide, keeping in mind the aforementioned uncertainties.

Correlation of columnar sections, when arranged by palaeolatitude, demonstrates the strong disparity in dominant faunal constituents between higher latitudes and the tropics during the Triassic. This disparity is a palaeobiogeographical feature that has increasingly attracted attention (Ezcurra 2010; Whiteside et al. 2011; Olsen et al. 2011; Irmis et al. 2011; Kent et al. 2014). Especially conspicuous is the complete absence of 
sauropodomorph dinosaurs from the Pangaean tropics and subtropics throughout the Late Triassic, along with the absence of capitosauroid, trematosauroid, and plagiosaurid temnospondyls during the Norian and Rhaetian in the tropics. Sauropodomorphs are locally very abundant at higher latitudes, and their absence in various tropical and subtropical Pangaean assemblages during the Triassic (Rowe et al. 2011) is striking in view of the wealth of skeletal remains of other tetrapods known from these occurrences.

For at least the Carnian and early Norian, Whiteside et al. (2011) argued for strong provinciality in the moist equatorial Pangaean region; there, traversodontid cynodonts are abundant, whereas remains of these therapsids are rare or absent and procolophonid reptiles are abundant in the Northern Hemisphere subtropics (as, for example, in the Evangeline Member of the Wolfville Formation). During the Middle Triassic, however, synapsids appear to be generally uncommon in tropical to subtropical Pangaean strata (as is the case for the Economy Member of the Wolfville Formation) while they are abundant at higher latitudes in both hemispheres (Sues and Fraser 2010). Thus, strong provinciality seems to characterize the entire Middle to the Late Triassic interval.

Even more striking than this provincialism is its apparent elimination at the ETE. The hallmark of this loss of provincialism is the appearance of basal sauropodomorphs in the McCoy Brook Formation, as documented by skeletal remains at Wasson Bluff and Otozoum tracks elsewhere. Loss of provincialism is also evident at coarser levels of temporal precision in both the Hartford basin of the Newark Supergroup in New England and in the Kayenta Formation and Navajo Sandstone of the American Southwest (Rowe et al. 2011). However, this observation must be tempered by the fact that sampling of pre-ETE Rhaetian-age tetrapod faunas is generally poor, with the exception of the Newark basin, where a reasonably abundant and diverse assemblage of tetrapod tracks lacks Otozoum or other plausibly sauropodomorph tracks (Olsen et al. 2002).

That said, even at lower levels of taxonomic precision, all of the tetrapods from the McCoy Brook Formation identifiable at the genus level have wide, sometimes cosmopolitan distributions during the Early Jurassic. The tetrapod assemblages from the McCoy Brook Formation are critical in showing that these taxa were present in the Pangaean subtropics at the beginning of the Jurassic. It is even possible that individual species spread very widely, as is the case for Pachygenelus cf. P. monus (Shubin et al. 1991). Similarly, Clevosaurus bairdi and Protosuchus micmac are both closely related to congeneric taxa elsewhere (Sues et al. 1994, 1996; Bonaparte and Sues 2006).

\section{CONCLUSIONS}

The Fundy basin in Nova Scotia and New Brunswick is the largest of the exposed rift basins of the Newark Supergroup in eastern North America, which formed during the continental rifting phase of the breakup of Pangaea. Its thick fill of sedimentary and igneous rocks ranges in age from the Late Permian to the Early Jurassic and contains a series of strata with significant assemblages of continental vertebrates. Following Olsen (1997), this succession can be divided into four tectonostratigraphic sequences (TS).

TS I is represented by the Honeycomb Point and possibly Lepreau formations, which appear to be of Permian age. The Honeycomb Point Formation has yielded only footprints and bone fragments to date. Based on correlation with the Ikakern Formation in Morocco it is probably of Late Permian age.

TS II is represented by the Wolfville Formation, which can be further divided into Economy Member, of probable Middle Triassic age, and the Evangeline Member, of early Late Triassic (Carnian) age. Both members have diverse assemblages of continental tetrapods that differ markedly from each other in their composition. The Economy Member has yielded remains of capitosauroid and trematosaurid temnospondyls as well as a diversity of mostly still poorly known reptiles. This tetrapod assemblage does not share any tetrapod taxa with that of the overlying Evangeline Member. The Evangeline Member has yielded the metoposaurid Metoposaurus bakeri (elsewhere known from Carnian-age strata of the Dockum Group in Texas) and a considerable diversity of reptiles, many of which are currently known only from this unit.

TS III comprises most of the Blomidon Formation, which is Norian to Rhaetian in age and has various horizons preserving often-abundant tracks and rare skeletal remains of tetrapods.

TS IV conformably overlies TS III and includes the late Rhaetian top of the Blomidon Formation and the McCoy Brook Formation, which overlies the North Mountain Basalt and is latest Rhaetian to earliest Jurassic (Hettangian) in age. The McCoy Brook Formation has yielded assemblages of mostly small continental tetrapods that include Canada's oldest known skeletal remains of dinosaurs. These assemblages are noteworthy for the absence of any of the characteristic Late Triassic tetrapod groups despite the fact that they represent a broad range of depositional environments. Recent work has correlated the GSSP for the base of the Jurassic (Hettangian) well above the radiometrically well constrained North Mountain Basalt. The occurrence of sauropodomorph dinosaurs from the McCoy Brook Formation at Wasson Bluff is likely of earliest Hettangian age whereas the other bone-bearing localities in that formation are of older, latest Rhaetian age. 
The Fundy basin is of global importance because it preserves the only known stratigraphically tightly constrained record of the biotic changes in continental ecosystems at the Triassic-Jurassic transition to date. Thus it provides critical data for testing hypotheses concerning the tempo and mode of the end-Triassic extinction event.

\section{ACKNOWLEDGEMENTS}

We dedicate this paper to the memory of our late friend and mentor Donald Baird, a pioneer in the study of Palaeozoic and early Mesozoic vertebrates from the Canadian Maritimes. Among the many colleagues with whom we have had the pleasure to work on aspects of the geology and vertebrate palaeontology of the Fundy basin we particularly thank Tim Fedak, David Brown, Dennis Kent, Neil Shubin, and Jessica Whiteside. We are indebted to Sterling Nesbitt, Bill Parker, Rainer Schoch, and Robin Whatley for discussions of various vertebrate fossils discussed in this paper. We thank Bill Amaral, Tim Fedak, George Hrynewich, Peter Kroehler, Eric Leighton, Amy Litt, Sterling Nesbitt, Steve Orzack, Louise Roth, Chuck Schaff, Neil Shubin, Dan Simanek, Bill Stevens, Alan Turner, Alex Werth, and Jessica Whiteside for discoveries of vertebrate fossils. Bill Amaral and Diane Scott prepared many of the fossils with their customary skill, and Diane Scott prepared the specimen drawings reproduced in Figures 31 and 32. We thank Tim Fedak and Nick Fraser for their helpful reviews of a draft of the manuscript and Rob Fensome and Chris White for their meticulous editing. We are grateful to Deborah Skilliter, Curator of Geology at the Nova Scotia Museum, her predecessor Bob Grantham, Katherine Ogden, Registrar at the Nova Scotia Museum, and Ken Adams, former Curator of the Fundy Geological Museum, for their unfailing enthusiastic support and help with permits and cataloguing. Our studies have received financial support from the National Science Foundation, the Lamont Climate Center, the National Geographic Society, and the Natural Sciences and Engineering Research Council of Canada.

\section{REFERENCES}

Ackermann, R.V., Schlische, R.W., and Olsen, P.E. 1995, Synsedimentary collapse of portions of the lower Blomidon Formation (Late Triassic), Fundy rift basin, Nova Scotia. Canadian Journal of Earth Science, 32, pp. 1965-1976. http://dx.doi.org/10.1139/e95-150

Armstrong, R.L. and Besancon, J. 1970. A Triassic timescale dilemma: K-Ar dating of Upper Triassic mafic igneous rocks, eastern USA and Canada and post-Upper Triassic plutons, western Idaho, USA. Eclogae Geologicae Helvetiae, 63, pp. 15-28.
Baird, D. 1957. Triassic reptile footprint faunules from Milford, New Jersey. Bulletin of the Museum of Comparative Zoology, Harvard College, 117, pp. 449-520.

Baird, D. 1963. Rhynchosaurs in the Late Triassic of Nova Scotia. Geological Society of America Special Paper, 73, p. 107.

Baird, D. 1986. Some Upper Triassic reptiles, footprints, and an amphibian from New Jersey. The Mosasaur, 3, pp. 125-153.

Baird, D. and Olsen, P.E. 1983. Late Triassic herpetofauna from the Wolfville Fm. of the Minas Basin (Fundy Basin) Nova Scotia, Canada. Geological Society of America, Abstracts with Program, 15, p. 122.

Baird, D. and Take, W.F. 1959. Triassic reptiles from Nova Scotia. Geological Society of America Bulletin, 70, pp. 1565-1566.

Barr, S.M. and White, C.E. 2005a. Bedrock geology of the Loch Lomond area (NTS 21 H/09). Saint John and Kings counties, New Brunswick. New Brunswick Department of Natural Resources and Energy. Minerals and Energy Division, Plate 2005-41, scale 1:50 000.

Barr, S.M. and White, C.E. 2005b. Bedrock geology of the Salmon River area (NTS 21 H/06). Saint John County, New Brunswick. New Brunswick Department of Natural Resources. Minerals, Policy and Planning Division, Plate 2005-42, scale 1:50 000.

Barrett, P.M. 2000. Prosauropod dinosaurs and iguanas: speculations on the diets of extinct reptiles. In Evolution of herbivory in terrestrial vertebrates: perspectives from the fossil record. Edited by H.-D. Sues. Cambridge University Press, Cambridge, pp. 42-78. http://dx.doi.org/10.1017/ CBO9780511549717.004

Blackburn, T.J., Olsen, P.E., Bowring, S.A., McLean, N.M., Kent, D.V., Puffer, J., McHone, G., Rasbury, E.T., and EtTouhami, M. 2013. Zircon U-Pb geochronology links the end-Triassic extinction with the Central Atlantic Magmatic Province. Science, 340, pp. 941-945. http:// dx.doi.org/10.1126/science.1234204

Bonaparte, J.F. and Sues, H.-D. 2006. A new species of Clevosaurus (Lepidosauria: Rhynchocephalia) from the Late Triassic of Rio Grande do Sul, Brazil. Palaeontology, 49, pp. 917-923. http://dx.doi.org/10.1111/j.14754983.2006.00568.x

Busbey, A.B. III, and Gow, C.E. 1984. A new protosuchian crocodile from the Upper Triassic Elliot Formation of South Africa. Palaeontologia africana, 25, pp. 127-149.

Cameron, B. and Jones, J.R. 1988. Plant fossils from the early Mesozoic Fundy Group of the Annapolis Valley region of Nova Scotia. In Mines and Minerals Branch, report of activities 1988, part A. Edited by D. MacDonald and Y. Brown. Nova Scotia Department of Mines and Energy, Report 88-3, pp. 173-177.

Carmichael, C.M. and Palmer, H.C. 1968. Paleomagnetism of the Late Triassic, North Mountain Basalt of Nova 
Scotia. Journal of Geophysical Research, 73, pp. 28112822. http://dx.doi.org/10.1029/JB073i008p02811

Carrano, M.T. and Wilson, J.A. 2001. Taxon distributions and the tetrapod track record. Paleobiology, 27, pp. 563-581. http://dx.doi.org/10.1666/0094-8373(2001)/027 $<0564$ :TDATTT>2.0.CO;2

Carroll, R.L., Belt, E.S., Dineley, D.L., Baird, D., and McGregor, D.C. 1972. Field excursion A59: Vertebrate paleontology of eastern Canada. Guidebook. TwentyFourth International Geological Congress, Montreal, Quebec, 113 p.

Case, E.C. 1931. Description of a new species of Buettneria, with a discussion of the brain case. Contributions from the Museum of Paleontology, University of Michigan, 3, pp. 187-206.

Christie-Blick, N. and Driscoll, N.W. 1995. Sequence stratigraphy. Annual Review of Earth and Planetary Sciences, 23, pp. 451-478. http://dx.doi.org/10.1146/ annurev.ea.23.050195.002315

Cirilli, S., Marzoli, A., Tanner, L., Bertrand, H., Buratti, N., Jourdan, F., Bellieni, G., Kontak, D., and Renne, P.R. 2009. Latest Triassic onset of the Central Atlantic Magmatic Province (CAMP) volcanism in the Fundy Basin (Nova Scotia): new stratigraphic constraints. Earth and Planetary Science Letters, 286, pp. 514-525. http:// dx.doi.org/10.1016/j.espl.2009.07.021

Cisneros, J.C. 2008. Phylogenetic relationships of procolophonid parareptiles with remarks on their geological record. Journal of Systematic Palaeontology, 6, pp. 345-366. http://dx.doi.org/10.1017/S147720190 7002350

Clark, J.M. 1986. Phylogenetic relationships of the crocodylomorph archosaurs. Unpublished Ph.D. dissertation, University of Chicago, Chicago, Illinois, 556 p.

Colbert, E.H. and Mook, C.C. 1951. The ancestral crocodilian Protosuchus. Bulletin of the American Museum of Natural History, 97, pp. 143-182.

Comeau, R.L. 1978. Summary drilling report, Annapolis Valley Project, Nova Scotia. For Getty Minerals Company Ltd, 6 April 1978, 58 p. [archived at Nova Scotia Natural Resources: ISN 4271, AN 432899, AR 21H/02B, Doc \# 54-K-20(01). (http://www.novascotia.ca/natr/meb/ download/ar_release_june2012.asp)].

Dawson, J.W. 1855. Acadian geology: an account of the geological structure and mineral resources of Nova Scotia, and portions of the neighbouring provinces of British America. Oliver and Boyd, Edinburgh, 388 p.

Dawson, J.W. 1891. The geology of Nova Scotia, New Brunswick, and Prince Edward Island, or Acadian geology. Fourth edition. MacMillan and Co., London, $694+103+37 \mathrm{p}$.

Deenen, M.H.L., Ruhl, M., Bonis, N.R., Krijgsman, W., Kuerschner, W.M., Reitsma, M., and Van Bergen, M.J.
2010. A new chronology for the end-Triassic mass extinction. Earth and Planetary Science Letters, 291, pp. 113-125. http://dx.doi.org/10.1016/j.espl.2010.01.003

Deenen, M.H.L., Krijgsman, W., and Ruhl, M. 2011. The quest for chron E23r at Partridge Island, Bay of Fundy, Canada: CAMP emplacement postdates the end-Triassic extinction event at the North American craton. Canadian Journal of Earth Sciences, 48, pp. 1282-1291. http:// dx.doi.org/10.1139/e11-015

Donohoe, H.V., Jr. and Wallace, P.I. 1978. Geology map of the Cobequid highlands. Preliminary map 78-1. Nova Scotia Department of Mines, Halifax, Nova Scotia, scale 1:50 000 .

Donohoe, H.V., Jr. and Wallace, P.I. 1982. Geological map of the Cobequid highlands (Colchester, Cumberland and Pictou counties), Nova Scotia. Map sheets 82-6, 82-7, 828, 82-9 and legend. Nova Scotia Department of Mines and Energy, Halifax, Nova Scotia, scale 1:50 000.

Dunay, R. 1975. Palynological summary, Mobil Gulf Chinampas N-37 Well history report D.145. CanadaNova Scotia Offshore Petroleum Board, Halifax, 8 p.

Dzik, J. 2003. A beaked herbivorous archosaur with dinosaur affinities from the early Late Triassic of Poland. Journal of Vertebrate Paleontology, 23, pp. 556-574. http://dx.doi. org/10.1671/A1097

Ellenberger, P. 1976. Une piste avec traces de soies épaisses dans le Trias Inférieur à Moyen de Lodève (Herault, France): Cynodontipus polythrix nov. gen., nov. sp.; les Cynodontes en France. Geobios, 9, pp. 769-787. http:// dx.doi.org/10.1016/S0016-6995(76)80078-2

Esque, T.C., and Peters, E.L. 1994. Ingestion of bones, stones, and soil by desert tortoises. Fish and Wildlife Research, 13, pp. 73-84.

Ezcurra, M.D. 2010. Biogeography of Triassic tetrapods: evidence for provincialism and driven sympatric cladogenesis in the early evolution of modern tetrapod lineages. Proceedings of the Royal Society B, 277, pp. 2547-2552. http://dx.doi.org/10.1098/rspb.2010.0508

Fedak, T.J. 2007. Description and evolutionary significance of the sauropodomorph dinosaurs from the Early Jurassic (Hettangian) McCoy Brook Formation. Unpublished Ph.D. dissertation. Dalhousie University, Halifax, Nova Scotia, $251 \mathrm{p}$.

Fedak, T.J., Sues, H.-D., and Olsen, P.E. In press. First record of the tritylodontid cynodont Oligokyphus and cynodont postcranial bones from the McCoy Brook Formation of Nova Scotia, Canada. Canadian Journal of Earth Sciences.

Fowell, S.J. and Traverse, A. 1995. Palynology and age of the upper Blomidon Formation, Fundy Basin, Nova Scotia. Review of Palaeobotany and Palynology, 86, pp. 211-233. http://dx.doi.org/10.1016/0034-6667(94)00147-C

Fraser, N.C. 1985. Vertebrate faunas from Mesozoic fissure deposits of Southwest Britain. Modern Geology, 9, pp. 273-300. 
Fraser, N.C. 1988. The osteology and relationships of Clevosaurus (Reptilia: Sphenodontida). Philosophical Transactions of the Royal Society of London B, 321, pp. 125-178. http://dx.doi.org/10.1098/rstb.1988.0092

Golebiowski, R. and Braunstein, R.E. 1988. A Triassic/ Jurassic boundary section in the Northern Calcareous Alps (Austria). In Excursion guide to the geologic sites of "rare events in geology". Workshop and field-trip sponsored by the IGCP Project 199 and the Austrian Ministry of Science and Research, Vienna, Austria, Sept. 12-17, 1988. Edited by H. Stradner (chair). Berichte der Geologischen Bundesanstalt, Vienna, pp. 39-46.

Gow, C.E. 1980. The dentitions of the Tritheledontidae (Therapsida: Cynodontia). Proceedings of the Royal Society of London B, 208, pp. 461-481. http://dx.doi. org/10.1098/rspb.1980.0063

Gow, C.E. 2000. The skull of Protosuchus haughtoni, an Early Jurassic crocodyliform from southern Africa. Journal of Vertebrate Paleontology, 20, pp. 49-56. http://dx.doi. org/10.1671/0272-4634(2000)020[0049:TSOPHA]2.0. $\mathrm{CO} ; 2$

Gower, D.J. 2003. Osteology of the early archosaurian reptile Erythrosuchus africanus Broom. Annals of the South African Museum, 110, pp. 1-88.

Grantham, R.G. 1986. Dinosaur tracks and mega-flutes in the Jurassic of Nova Scotia. In Dinosaur tracks and traces. Edited by D.D. Gillette and M.G. Lockley. Cambridge University Press, Cambridge, pp. 281-284.

Groenewald, G.H. 1991. Burrow casts from the LystrosaurusProcolophon Assemblage Zone, Karoo Sequence, South Africa. Koedoe, 34, pp. 13-22. http://dx.doi.org/10.4102/ koedoe.v34i1.409

Guex, J., Schoene, B., Bartolini, A., Spangenberg, J., Schaltegger, U., O'Dogherty, L., Taylor, D., Bucher, H., and Atudorei, V. 2012. Geochronological constraints on postextinction recovery of the ammonoids and carbon cycle perturbations during the Early Jurassic. Palaeogeography, Palaeoclimatology, Palaeoecology, 346-347, pp. 1-11. http://dx.doi.org/10.1016/j.palaeo.2012.04.030

Hassan, H.S. 2000. Sedimentology and paleontology of the Lower Jurassic Scots Bay Formation, Bay of Fundy, Nova Scotia, Canada. Unpublished M.Sc. thesis, Acadia University, Wolfville, Nova Scotia, 180 p.

Haubold, H. 1971. Ichnia amphibiorum et reptiliorum fossilium. In Handbuch der Paläoherpetologie. Teil 18. Edited by O. Kuhn. Gustav Fischer Verlag, Stuttgart and Portland, $124 \mathrm{p}$.

Haubold, H. and Klein, H. 2000. Die dinosauroiden Fährten Parachirotherium-Atreipus-Grallator aus dem unteren Mittelkeuper (Obere Trias: Ladin, Karn, ?Nor) in Franken. Hallesches Jahrbuch für Geowissenschaften B, 22, pp. 59-85.

Hayatsu, A. 1979. K-Ar isochron age of the North Mountain Basalt, Nova Scotia. Canadian Journal of Earth Sciences,
16, pp. 973-975. http://dx.doi.org/10.1139/e79-085

Hennig, E. 1922. Die Säugerzähne des württembergischen Rhät-Lias-Bonebeds. Neues Jahrbuch für Mineralogie, Geologie und Paläontologie, Beilage-Band, 46, pp. 181267.

Hesselbo, S.P., Robinson, S.A., Surlyk, F., and Piasecki, S. 2002. Terrestrial and marine extinction at the TriassicJurassic boundary synchronized with major carbon-cycle perturbation: a link to initiation of massive volcanism? Geology, 30, pp. 251-254. http://dx.doi.org/10.1130/00917613(2002)030<0251:tameat $>2.0 . C O ; 2$

Hillebrandt, A.von and Krystyn, L. 2009. On the oldest Jurassic ammonites of Europe (Northern Calcareous Alps, Austria) and their global significance. Neues Jahrbuch für Geologie und Paläontologie, Abhandlungen, 253, pp. 163-195. http://dx.doi.org/10.1127/0077-77 49/2009/0253-0163

Hillebrandt, A.von, Krystyn, L., and Kuerschner, W.M. 2007. A candidate GSSP for the base of the Jurassic in the Northern Calcareous Alps (Kuhjoch section, Karwendel Mountains, Tyrol, Austria). International Subcommission on Jurassic Stratigraphy Newsletter, 34, pp. 2-20.

Hillebrandt, A.von, Krystyn, L., Kürschner, W.M., Bonis, N.R., Ruhl. M., Richoz, S., Schobben, M.A.N., Urlichs, M., Bown, P.R., Kment, K., McRoberts, C.A., Simms, M., and Tomãsovych, A. 2013. The Global Stratotype Section and Point (GSSP) for the base of the Jurassic System at Kuhjoch (Karwendel Mountains, Northern Calcareous Alps, Tyrol, Austria). Episodes, 36, pp. 162-198.

Hitchcock, C.H. 1889. Recent progress in ichnology. Proceedings of the Boston Society of Natural History, 24, pp. 117-127.

Hodych, J.P. and Dunning, G.R. 1992. Did the Manicouagan impact trigger end-of-Triassic mass extinction? Geology, 20, pp. 51-54. http://dx.doi.org/10.1130/00917613(1992)020<0051:DTMITE >2.3.CO;2

Hopson, J.A. 1984. Late Triassic traversodont cynodonts from Nova Scotia and southern Africa. Palaeontologia africana, 25, pp. 181-201.

Huber, P., Lucas, S.G., and Hunt, A.P. 1993. Vertebrate biochronology of the Newark Supergroup Triassic, eastern North America. In The nonmarine Triassic. Edited by S.G. Lucas and M. Morales. New Mexico Museum of Natural History \& Science Bulletin, 3, pp. 179-186.

Hubert, J.F. and Forlenza, M.F. 1988. Sedimentology of braided-river deposits in Upper Triassic Wolfville redbeds, southern shore of Cobequid Bay, Nova Scotia, Canada. In Triassic-Jurassic rifting, continental breakup and the origin of the Atlantic Ocean and passive margins. Part A. Edited by W. Manspeizer. Elsevier, New York, pp. 231-247. http://dx.doi.org/10.1016/B978-0-444-429032.50014-2

Hubert, J.F., and Hyde, M.G. 1982. Sheet-flow deposits of graded beds and mudstones on an alluvial sandflat-playa 
system: Upper Triassic Blomidon redbeds, St. Mary's Bay, Nova Scotia. Sedimentology, 29, pp. 457-474. http:// dx.doi.org/10.1111/j.1365-3091.1982.tb01730.x

Hubert, J.F. and Mertz, K.A. 1984. Eolian sandstones in Upper Triassic-Lower Jurassic red beds of the Fundy Basin, Nova Scotia. Journal of Sedimentary Petrology, 54, pp. 798-810. http://dx.doi.org/10.1306/212F84FE2B24-11D7-8648000102C1865D

Hunt, A.P. 1993. A revision of the Metoposauridae (Amphibia: Temnospondyli) of the Late Triassic with description of a new genus from the western United States. Museum of Northern Arizona Bulletin, 59, pp. 67-97.

Irmis, R.B., Parker, W.G., Nesbitt, S.J., and Liu, J. 2007. Early ornithischian dinosaurs: the Triassic record. Historical Biology, 19, pp. 3-22. http://dx.doi. org/10.1080/08912960600719988

Irmis, R.B., Mundil, R., Martz, J.W., and Parker, W.G. 2011. High-resolution $\mathrm{U}-\mathrm{Pb}$ ages from the Upper Triassic Chinle Formation (New Mexico, USA) support a diachronous rise of dinosaurs. Earth and Planetary Science Letters, 309, pp. 258-267. http://dx.doi.org/10.1016/j.espl.2011.07.015

Jalil, N.-E. 1999. Continental Permian and Triassic vertebrate localities from Algeria and Morocco and their stratigraphic correlations. Journal of African Earth Sciences, 29, pp. 219-226. http://dx.doi.org/10.1016/ S0899-5362(99)00091-3

Jalil, N.-E. and Janvier, P. 2005. Les pareiasaures (Amniota, Parareptilia) du Permien supérieur du Bassin d'Argana, Maroc. Geodiversitas, 27, pp. 35-132.

Jones, M.E.H. 2006. The Early Jurassic clevosaurs from China (Diapsida: Lepidosauria). In The Triassic-Jurassic terrestrial transition. Edited by J.D. Harris, S.G. Lucas, J.A. Spielmann, M.G. Lockley, A.R.C. Milner, and J.I. Kirkland. New Mexico Museum of Natural History \& Science Bulletin, 37, pp. 548-561.

Jong, W. 1985. The subsurface lithostratigraphy of the Triassic Blomidon and Upper Wolfville formations (Fundy basin) of the central Annapolis Valley, Nova Scotia. Unpublished B.Sc. Thesis, Acadia University, Wolfville, Nova Scotia, $142 \mathrm{p}$.

Kent, D.V. and Olsen, P.E., 1999. Astronomically tuned geomagnetic polarity time scale for the Late Triassic. Journal of Geophysical Research, 104, pp. 12831-12841. http://dx.doi.org/10.1029/1999JB900076

Kent, D.V., and Olsen, P.E. 2000. Magnetic polarity stratigraphy and paleolatitude of the Triassic-Jurassic Blomidon Formation in the Fundy basin (Canada): implications for early Mesozoic tropical climate gradients. Earth and Planetary Science Letters, 179, pp. 311-324. http://dx.doi.org/10.1016/S0012-821X(00)00117-5

Kent, D.V., Olsen, P.E., and Witte, W.K. 1995. Late Triassic-earliest Jurassic geomagnetic polarity sequence and paleolatitudes from drill cores in the Newark rift basin, eastern North America. Journal of Geophysical Research, 100(B8), pp. 14965-14998. http://dx.doi. org/10.1029/95JB01054

Kent, D.V., Malnis, P.S., Colombi, C.E., Alcober, O.A., and Martínez, R.N. 2014. Age constraints on the dispersal of dinosaurs in the Late Triassic from magnetochronology of the Los Colorados Formation (Argentina). Proceedings of the National Academy of Sciences USA, 111, pp. 79587963. http://dx.doi.org/10.1073/pnas.1402369111

Keppie, J.D. 1979. Geological map of the Province of Nova Scotia. Nova Scotia Department of Mines, Halifax, Nova Scotia, scale 1:500 000.

Klein, G.de V. 1960. Stratigraphy, sedimentary petrology, and structure of Triassic sedimentary rocks, Maritime Provinces, Canada. Ph.D. dissertation, Yale University, New Haven, Connecticut, 262 p.

Klein, G.de V. 1962. Triassic sedimentation, Maritime Provinces, Canada. Geological Society of America Bulletin, 73, pp. 1127-1146. http://dx.doi.org/10.1130/0016-7606 (1962)73[1127:TSMPC]2.0.CO;2

Klein, H., Voigt, S., Saber, H., Schneider, J.W., Hminna, A., Fischer, J., Lagnaoui, A., and Brosig, A. 2011. First occurrence of a Middle Triassic tetrapod ichnofauna from the Argana Basin (Western High Atlas, Morocco). Palaeogeography, Palaeoclimatology, Palaeoecology, 307, pp. 218-231. http:dx.doi.org/10.1016/j.palaeo.2011 .05 .021

Kozur, H.W. and Weems, R.E. 2010. The biostratigraphic importance of conchostracans in the continental Triassic of the northern hemisphere. In The Triassic timescale. Edited by S.G. Lucas. Geological Society of London, Special Publications, 334, pp. 315-417. http://dx.doi. org/10.1144/SP334.13

Kühne, W.G. 1956. The Liassic therapsid Oligokyphus. British Museum (Natural History), London, 150 p.

Kyte, F.T., Tanner, L.H., and Walker, A.E. 2008. Anomalous iridium at the palynological Triassic-Jurassic boundary in the Fundy Basin, Partridge Island, Nova Scotia. Lunar and Planetary Science Conference, 39, abstract \#2463.

Leleu, S. and Hartley, A.J. 2010. Controls on the stratigraphic development of the Triassic Fundy Basin, Nova Scotia: implications for the tectonostratigraphic evolution of Triassic Atlantic rift basins. Journal of the Geological Society of London, 167, pp. 437-454. http://dx.doi. org/10.1144/0016-76492009-092

Leleu, S., Hartley, A.J., and Williams, B.P.J. 2009. Large-scale alluvial architecture and correlation in a Triassic pebbly braided river system, lower Wolfville Formation (Fundy Basin, Nova Scotia, Canada). Journal of Sedimentary Research, 79, pp. 265-286. http://dx.doi.org/10.2110/ jsr.2009.034

Leleu, S., van Lanen, X.M.T., and Hartley, A.J. 2010. Controls on the architecture of a Triassic sandy fluvial system, Wolfville Formation, Fundy Basin, Nova Scotia: 
implications for the interpretation and correlation of ancient fluvial successions. Journal of Sedimentary Research, 80, pp. 867-883. http://dx.doi.org/10.2110/ jsr. 2010.080

Li, J.-L. 1983. Tooth replacement in a new genus of procolophonid from the Early Triassic of China. Palaeontology, 26, pp. 567-583.

Liew, Y.-C. 1976. Structure, geochemistry, and stratigraphy of Triassic rocks, North Shore of Minas Basin, Nova Scotia. Unpublished M.Sc. thesis, Acadia University, Wolfville, Nova Scotia, $181 \mathrm{p}$.

Lockley, M.G. and Harris, J.D. 2011. Two-toed tracks through time: on the trail of "raptors" and their allies. In Dinosaur Tracks 2011: an international symposium, Obernkirchen, April 14-17, 2011. Abstract Volume and Field Guide to Excursions. Edited by A. Richter and M. Reich. Universitätsdrucke Göttingen, p. 34.

Lockley, M.G. and Lucas, S.G. 2013. Evazoum gatewayensis, a new Late Triassic archosaurian ichnospecies from Colorado: implications for footprints in the ichnofamily Otozoidae. In The Triassic System. Edited by L.H. Tanner, J.A. Spielmann, and S.G. Lucas. New Mexico Museum of Natural History \& Science Bulletin, 61, pp. 345-353.

Lockley, M.G., Lucas, S.G., and Hunt, A.P. 2006. Evazoum and the renaming of Northern Hemisphere "Pseudotetrasauropus": implications for tetrapod ichnotaxonomy at the Triassic-Jurassic boundary. In The Triassic-Jurassic terrestrial transition. Edited by J.D. Harris, S.G. Lucas, J.A. Spielmann, M.G. Lockley, A.R.C. Milner, and J.I. Kirkland. New Mexico Museum of Natural History \& Science Bulletin, 37, pp. 199-206.

Lucas, S.G. 1998. Global Triassic tetrapod biostratigraphy and biochronology. Palaeogeography, Palaeoclimatology, Palaeoecology, 143, pp. 347-384. http://dx.doi. org/10.10126/S0031-0182(98)00117-5

Lucas, S.G., and Heckert, A.B. 2011. Late Triassic aetosaurs as the trackmaker of the tetrapod footprint ichnotaxon Brachychirotherium. Ichnos, 18, pp. 197-208. http:// dx.doi.org/10.1080/10420940.2011.632456

Lucas, S.G. and Schoch, R.R. 2002. Triassic temnospondyl biostratigraphy, biochronology and correlation of the German Buntsandstein and North American Moenkopi Formation. Lethaia, 35, pp. 97-106. http://dx.doi. org/10.1111/j.1502-3931.2002.tb00071.x

Lucas, S.G., Heckert, A.B., and Hotton, N. III. 2002. The rhynchosaur Hyperodapedon from the Upper Triassic of Wyoming and its global biostratigraphic significance. In Upper Triassic stratigraphy and paleontology. Edited by A.B. Heckert and S.G. Lucas. New Mexico Museum of Natural History \& Science Bulletin, 21, pp. 149-156.

Lull, R.S. 1953. Triassic life of the Connecticut Valley. (Revised.) State of Connecticut, State Geological and Natural History Survey, Bulletin, 81, pp. 1-331.

Luo, Z. and Sun, A. 1994. Oligokyphus (Cynodontia:
Tritylodontidae) from the Lower Lufeng Formation (Lower Jurassic) of Yunnan, China. Journal of Vertebrate Paleontology, 13, pp. 477-482. http://dx.doi.org/10.1080/ 02724634.1994 .10011526

Luttrell, G.W. 1989. Stratigraphic nomenclature of the Newark Supergroup of eastern North America. U.S. Geological Survey Bulletin, 1572, pp. 1-136.

MacNaughton, R.B. and Pickerill, R.K. 2010. A cautionary note on the use of invertebrate trace fossils for correlation in the Triassic-Jurassic Fundy Group. Atlantic Geology, 46, pp. 90-94. http://dx.doi.org/10.4138/atlgeol.2010.005

Martinelli, A.G., Bonaparte, J.F., Schultz, C.L., and Rubert, R. 2005. A new tritheledontid (Therapsida, Eucynodontia) from the Late Triassic of Rio Grande do Sul (Brazil) and its phylogenetic relationships among carnivorous nonmammalian eucynodonts. Ameghiniana, 42, pp. 191-208.

Marzoli, A., Renne, P.R., Piccirillo, E.M., Ernesto, M., Bellieni, G., and De Min, A. 1999. Extensive 200-millionyear-old continental flood basalts of the Central Atlantic Magmatic Province. Science, 284, pp. 616-618. http:// dx.doi.org/10.1126/science.284.5414.616

McElwain, J.C., Beerling, D.J., and Woodward, F.I. 1999. Fossil plants and global warming at the Triassic-Jurassic boundary. Science, 285, pp. 1386-1390. http://dx.doi.org/ $10.1126 /$ science.285.5432.1386

McHone, J.G. 2011. Triassic basin stratigraphy at Grand Manan, New Brunswick, Canada. Atlantic Geology, 47, pp. 125-137. http://dx.doi.org/10.4138/atlgeol.2011.006

McLeod, M.J. and Johnson, S.G. 1998. Bedrock geological compilation of the Musquash area (NTS 21 G/01), Saint John, Charlotte and Kings counties, New Brunswick. New Brunswick Department of Natural Resources and Energy, Minerals and Energy Division, Plate 98-22, scale 1:50 000.

McRoberts, C.A., Ward, P.D., and Hesselbo, S. 2007. A proposal for the base Hettangian Stage (= base Jurassic System) GSSP at New York Canyon (Nevada, USA) using carbon isotopes. International Subcommission on Jurassic Stratigraphy Newsletter, 34, pp. 43-49.

Mertz, K.A. and Hubert, J.F. 1990. Cycles of sand-flat sandstone and playa-lacustrine mudstone in the TriassicJurassic Blomidon redbeds, Fundy rift basin, Nova Scotia: implications for tectonic and climatic controls. Canadian Journal of Earth Sciences, 27, pp. 442-451. http://dx.doi. org/10.1139/e90-039

Moore, R.G., Ferguson, S.A., Boehner, R.C., and Kennedy, C.M. 2009. Bedrock geology map of the WolfvilleWindsor Area, NTS sheet 21H/01 and part of 21A/16, Hants and Kings Counties, Nova Scotia. Nova Scotia Department of Natural Resources, Minerals Resources Branch, Open File Map ME 2000-3, version 2, 1:50,000.

Mueller, B.D. 2007. Koskinonodon Branson and Mehl, 1929, a replacement name for the preoccupied temnospondyl Buettneria Case, 1922. Journal of Vertebrate Paleontology, 27, p. 225. http://dx.doi.org/10.1671/02724634(2007)27[225:KBAMAR]2.0.CO;2 
Muttoni, G., Kent, D.V., Olsen, P.E., Di Stefano, P., Lowrie, W., Bernasconi, S., and Martín Hernández, F. 2004. Tethyan magnetostratigrapy from Pizzo Mondello and correlation to the Late Triassic Newark APTS. Geological Society of America Bulletin, 116, pp. 1043-1058. http:// dx.doi.org/10.1130/B25326.1

NACSN (North American Commission on Stratigraphic Nomenclature). 2005. North American Stratigraphic Code. American Association of Petroleum Geologists Bulletin, 89, pp. 1547-1591. http://dx.doi.org/10.1306/ 07050504129

Nadon, G.C. and Middleton, G.V. 1985. The stratigraphy and sedimentology of the Fundy Group (Triassic) of the St. Martins area, New Brunswick. Canadian Journal of Earth Sciences, 22, pp. 1183-1203. http://dx.doi.org/10.1139/ e85-121

Nesbitt, S.J. 2011. The early evolution of archosaurs: relationships and the origin of major clades. Bulletin of the American Museum of Natural History, 353, pp. 1-292. http://dx.doi.org/10.1206/352.1

Olsen, P.E. 1978. On the use of the term Newark for Triassic and Early Jurassic rocks of eastern North America. Newsletter on Stratigraphy, 7, pp. 90-95.

Olsen, P.E. 1981. Comment and reply on 'Eolian dune field of Late Triassic age, Fundy Basin, Nova Scotia.' Geology, 9, pp. 557-559. http://dx.doi.org/10.1130/00917613(1981)9<557:CAROED>2.0.CO;2

Olsen, P.E. 1988. Paleontology and paleoecology of the Newark Supergroup (Early Mesozoic, eastern North America). In Triassic-Jurassic rifting, continental breakup and the origin of the Atlantic Ocean and passive margins. Edited by W. Manspeizer. Elsevier, New York, pp. 186-230. http://dx.doi.org/10.1016/B978-0-444-42903-2.50013-0

Olsen, P.E. 1995a. A new approach for recognizing track makers. Geological Society of America Abstracts with Programs, 27, p. 72.

Olsen, P.E., 1995b. Paleontology and paleoenvironments of Early Jurassic age strata in the Walter Kidde Dinosaur Park (New Jersey, USA). In Field guide and proceedings of the Twelfth Annual Meeting of the Geological Association of New Jersey. Edited by J.E.B. Baker. William Patterson College, Patterson, New Jersey, pp. 156-190.

Olsen, P.E. 1997. Stratigraphic record of the early Mesozoic breakup of Pangea in the Laurasia-Gondwana rift system. Annual Reviews of Earth and Planetary Sciences, 25, pp. 337-401. http://dx.doi.org/10.1146/annurev. earth.25.1.337

Olsen, P.E., and Baird, D. 1986. The ichnogenus Atreipus and its significance for Triassic biostratigraphy. In The beginning of the Age of Dinosaurs: faunal change across the Triassic-Jurassic boundary. Edited by K. Padian. Cambridge University Press, New York, pp. 61-87.

Olsen, P.E. and Et-Touhami, M. 2008. Field Trip \#1: Tropical to subtropical syntectonic sedimentation in the Permian to Jurassic Fundy rift basin, Atlantic Canada, in relation to the Moroccan conjugate margin. Central Atlantic Conjugate Margins Conference Halifax, Nova Scotia, Canada, August 2008, 121 p.

Olsen, P.E. and Flynn, J.J. 1989. Field guide to the vertebrate paleontology of Late Triassic rocks in the southwestern Newark Basin (Newark Supergroup, New Jersey and Pennsylvania). The Mosasaur, 4, pp. 1-35.

Olsen, P.E. and Padian, K. 1986. Earliest records of Batrachopus from the Southwest U.S., and a revision of some early Mesozoic crocodylomorph ichnogenera. In The beginning of the Age of Dinosaurs: faunal change across the Triassic-Jurassic boundary. Edited by K. Padian. Cambridge University Press, New York, pp. 259-273.

Olsen, P.E. and Rainforth, E.C. 2003. The Early Jurassic ornithischian dinosaurian ichnogenus Anomoepus. In The great rift valleys of Pangea in eastern North America. Vol. 2: sedimentology, stratigraphy, and paleontology. Edited by P.M. LeTourneau and P.E. Olsen. Columbia University Press, New York, pp. 314-367.

Olsen, P.E. and Schlische, R.W. 1990. Transtensional arm of the earlyMesozoic Fundy riftbasin:penecontemporaneous faulting and sedimentation. Geology, 18, pp. 695-698. http://dx.doi.org/10.1130/0091-7613(1990)018<0695:TA OTEM $>2.3 . \mathrm{CO} ; 2$

Olsen, P.E., Shubin, N.H., and Anders, M.E. 1987. Early Jurassic tetrapod assemblages constrain Triassic-Jurassic extinction event. Science, 237, pp. 1025-1029. http:// dx.doi.org/10.1126/science.3616622

Olsen, P.E., Schlische, R.W., and Gore, P.J.W. (eds.) 1989. Field guide to the tectonics, stratigraphy, sedimentology, and paleontology of the Newark Supergroup, eastern North America. 28th International Geological Congress, Guidebook for Field Trip T351. American Geophysical Union, Washington, DC, $174 \mathrm{p}$.

Olsen, P.E., Fowell, S.J., and Cornet, B. 1990. The TriassicJurassic boundary in continental rocks of eastern North America: a progress report. In Global catastrophes in earth history; an interdisciplinary conference on impacts, volcanism, and mass mortality. Edited by V.L. Sharpton and P.D. Ward. Geological Society of America Special Paper, 247, pp. 585-593. http://dx.doi.org/10.1130/SPE 247-p585

Olsen, P.E., Kent, D.V., Cornet, B., Witte, W.K., and Schlische, R.W. 1996. High-resolution stratigraphy of the Newark rift basin (early Mesozoic, eastern North America). Geological Society of America Bulletin, 108, pp. 40-77. http://dx.doi.org/10.1130/0016-7606(1996)108<0040:HR SOTN $>2.3 . \mathrm{CO} ; 2$

Olsen, P.E., Smith, J.B., and McDonald, N.G. 1998. Type material of the type species of the classic theropod footprint genera Eubrontes, Anchisauripus, and Grallator (Early Jurassic, Hartford and Deerfield basins, Connecticut and Massachusetts, U.S.A.). Journal of 
Vertebrate Paleontology, 18, pp. 586-601. http://dx.doi.or g/10.1080/02724634.1998.10011086

Olsen, P.E., Kent, D.V., Fowell, S.J., Schlische, R.W., Withjack, M.O., and LeTourneau, P.M. 2000. Implications of a comparison of the stratigraphy and depositional environments of the Argana (Morocco) and Fundy (Nova Scotia, Canada) Permian-Jurassic basins. In Le Permien et le Trias du Maroc. Actes de la première réunion du Groupe Marocain du Permien et du Trias. Edited by M. Oujidi and M. Et-Touhami. Hilal Impression, Oujda, pp. 165-183.

Olsen, P.E., Kent, D.V., Et-Touhami, M., Fowell, S.J., and Witte, W.K. 2002. Cyclicity, time scale, and correlation of the Triassic and Early Jurassic rift strata of the Argana Basin, Morocco. In Troisième réunion du Groupe Marocain du Permien et du Trias, Casablanca, 18-20 Avril 2002, Résumés. Edited by R. Essamoud and F. Ekamel. Casablanca, pp. 29-30.

Olsen, P.E., Kent, D.V., Et-Touhami, M., and Puffer, J.H. 2003a. Cyclo-, magneto-, and bio-stratigraphic constraints on the duration of the CAMP event and its relationship to the Triassic-Jurassic boundary. In The Central Atlantic Magmatic Province: insights from fragments of Pangea. Edited by W.E. Hames, J.G. McHone, P.R. Renne, and C. Ruppel. Geophysical Monograph Series, 136, pp. 7-32. http://dx.doi.org/10.1029/136GM02

Olsen, P.E., Kent, D.V., and Et-Touhami, M. 2003b. Chronology and stratigraphy of the Fundy and related Nova Scotia offshore basins and Morocco based on core and outcrop. In Conventional core workshop. Edited by D. Brown. Geological Society of America (NE Section) and Atlantic Geoscience Society, Halifax, Nova Scotia, pp. 51-63.

Olsen, P.E., Whiteside, J.H., and Fedak, T. 2005a. TriassicJurassic faunal and floral transition in the Fundy basin, Nova Scotia. Field Guide for North American Paleontological Convention 2005, Halifax, 52 p.

Olsen, P.E., Whiteside, J.H., and Fedak, T. 2005b. Field Trip A7: The Triassic-Jurassic faunal and floral transition in the Fundy basin, Nova Scotia. Geological Association of Canada, Mineralogical Association of Canada, Canadian Society of Petroleum Geologists, Canadian Society of Soil Sciences Joint Meeting, Halifax, May 2005. Atlantic Geoscience Society Special Publication Number 26, 53 p.

Olsen, P.E., Kent, D.V., and Whiteside, J.H. 2011. Implications of the Newark Supergroup-based astrochronology and geomagnetic polarity time scale (Newark-APTS) for the tempo and mode of the early diversification of the Dinosauria. Earth and Environmental Science Transactions of the Royal Society of Edinburgh, 101, pp. 201-229. http://dx.doi.org/10.1017/S1755691011020032

Olsen, P.E., Kent, D.V., and Et-Touhami, M. 2012. Determining the concentration of individual eruptive events of the CAMP: distinguishing interflow hiatuses from subterranean alteration and void infilling. Geophysical Research Abstracts, 14, EGU2012-13599.

Parker, W.G., Irmis, R.B., Nesbitt, S.J., Martz, J.W., and Browne, L.S. 2005. The Late Triassic pseudosuchian Revueltosaurus callenderi and its implications for the diversity of early ornithischian dinosaurs. Proceedings of the Royal Society of London B, 272, pp. 963-969. http:// dx.doi.org/10.1098/rspb.2004.3047

Peyer, K., Carter, J.G., Sues, H.-D., Novak, S.E., and Olsen, P.E. 2008. A new suchian archosaur from the Upper Triassic of North Carolina. Journal of Vertebrate Paleontology, 28, pp. 363-381. http://dx.doi.org/10.1080/0272-4634 (2008)28[363:ANSAFT]2.0.CO;2

Poole, E. G. 1979. The Triassic-Jurassic boundary in Great Britain. Geological Magazine, 116, pp. 303-311. http:// dx.doi.org/10.1017/S0016756800043788

Powers, S. 1915. The Acadian Triassic. Ph.D. dissertation, Harvard University, Cambridge, Massachusetts, 209 p.

Powers, S. 1916. The Acadian Triassic. Journal of Geology, 24, pp. 1-26, 105-122, 254-268. http://dx.doi. org/10.1086/622299, http://dx.doi.org/10.1086/622313, http://dx.doi.org/10.1086/622327

Rainforth, E.C. 2003. Revision and re-evaluation of the Early Jurassic dinosaurian ichnogenus Otozoum. Palaeontology, 46, pp. 803-838. http://dx.doi.org/10.1111/1475-4983. 00320

Rainforth, E.C. 2005. Ichnotaxonomy of the fossil footprints of the Connecticut Valley (Early Jurassic, Newark Supergroup, Connecticut and Massachusetts). Ph.D. dissertation, Columbia University, New York, 1302 p.

Redfield, W.C. 1856. On the relations of the fossil fishes of the sandstone of Connecticut and the Atlantic States to the Liassic and Oolitic periods. American Journal of Science, Series 2, 22, pp. 357-363.

Rieppel, O., Jiang, D.-Y., Fraser, N.C., Hao, W.-C., Motani, R., Sun, Y.-L., and Sun, Z.-Y. 2010. Tanystropheus cf. T. longobardicus from the early Late Triassic of Guizhou Province, southwestern China. Journal of Vertebrate Paleontology, 30, pp. 1082-1089. http://dx.doi.org/10.10 80/02724634.2010.483548

Robinson, P.L. 1957. An unusual sauropsid dentition. Journal of the Linnean Society (Zoology), 43, pp. 283293.

Rowe, T.B., Sues, H.-D., and Reisz, R.R. 2011. Dispersal and diversity in the earliest North American sauropodomorph dinosaurs, with a description of a new taxon. Proceedings of the Royal Society B, 278, pp. 1044-1053. http://dx.doi. org/10.1098/rspb.2010.1867

Ryan, J.D. and Willard, B. 1947. Triassic footprints from Bucks County, Pennsylvania. Proceedings of the Pennsylvania Academy of Science, 21, pp. 91-93.

Säilä, L.K. 2010. Osteology of Leptopleuron lacertinum Owen, a procolophonoid parareptile from the Upper Triassic of Scotland, with remarks on ontogeny, ecology and 
affinities. Earth and Environmental Science Transactions of the Royal Society of Edinburgh, 101, pp. 1-25. http:// dx.doi.org/10.1017/S1755691010009138

Sarjeant, W.A.S. and Stringer, P. 1978. Triassic reptile tracks in the Lepreau Formation, southern New Brunswick, Canada. Canadian Journal of Earth Sciences, 15, pp. 594602. http://dx.doi.org/10.1139/e78-064

Schaller, M.F., Wright, J.D., and Kent, D.V. 2011. Atmospheric $\mathrm{pCO}_{2}$ perturbations associated with the Central Atlantic Magmatic Province. Science, 331, pp. 1404-1409. http:// dx.doi.org/10.1126/science.1199011

Schaller, M.F., Wright, J.D., Kent, D.V., and Olsen, P.E. 2012. Rapid emplacement of the Central Atlantic Magmatic Province as a net sink for $\mathrm{CO}_{2}$. Earth and Planetary Science Letters, 323-324, pp. 27-39. http://dx.doi.org/10.1016/j. epsl.2011.12.028

Schoch, R.R. 2011. How diverse is the temnospondyl fauna in the Lower Triassic of southern Germany? Neues Jahrbuch für Geologie und Paläontologie, Abhandlungen, 261, pp. 49-60. http://dx.doi.org/10.1127/0077-7749/2011/0147

Schoch, R.R. and Milner, A.R. 2000. Stereospondyli. In Handbuch der Paläoherpetologie. Teil 3B. Edited by $\mathrm{P}$. Wellnhofer. Verlag Dr. Friedrich Pfeil, Munich, 203 p.

Schoene, B., Crowley, J.L., Condon, D.C., Schmitz, M.D., and Bowring, S.A. 2006. Reassessing the uranium decay constants for geochronology using ID-TIMS U-Pb data. Geochimica et Cosmochimica Acta, 70, pp. 426-445. http://dx.doi.org/10.1016/j.gca.2005.09.007

Schoene, B., Guex, J., Bartolini, A., Schaltegger, U., and Blackburn, T.J. 2010. Correlating the end-Triassic mass extinction and flood basalt volcanism at the $100 \mathrm{ka}$ level. Geology, 38, pp. 387-390. http://dx.doi.org/10.1130/ G30683.1

Sellwood, B.W., and Valdes, P.J. 2006. Mesozoic climates: general circulation models and the rock record. Sedimentary Geology, 190, pp. 269-287. http://dx.doi. org/10.1016/j.sedgeo.2006.05.013

Sennikov, A.G. 2011. New tanystropheids (Reptilia: Archosauromorpha) from the Triassic of Europe. Paleontological Journal, 45, pp. 90-104. http://dx.doi. org/10.1134/S0031030111010151

Sereno, P.C. 1991. Lesothosaurus, "fabrosaurids," and the early evolution of Ornithischia. Journal of Vertebrate Paleontology, 11, pp. 168-197. http://dx.doi.org/10.1080/ 02724634.1991.10011386

Shubin, N.H., Crompton, A.W., Sues, H.-D., and Olsen, P.E. 1991. New fossil evidence on the sister-group of mammals and early Mesozoic faunal distributions. Science, 251, pp. 1063-1065. http://dx.doi.org/10.1126/ science.251.4997.1063

Shubin, N.H., Olsen, P.E., and Sues, H.-D. 1994. Early Jurassic small tetrapods from the McCoy Brook Formation of Nova Scotia, Canada. In In the shadow of the dinosaurs: early Mesozoic tetrapods. Edited by N.C.
Fraser and H.-D. Sues. Cambridge University Press, New York, pp. 242-250.

Skilliter, C.C. 1996. The sedimentology of Triassic fluvial and aeolian deposits of Carrs Brook, Colchester County, Nova Scotia. Unpublished B.Sc. thesis, Saint Mary's University, Halifax, Nova Scotia, 124 p.

Smoot, J.P. and Castens-Seidel, B. 1982. Sedimentary fabrics produced in playa sediments by efflorescent salt crusts: an explanation for "adhesion ripples". In Abstracts of Papers, 11th International Congress on Sedimentology, McMaster University, Hamilton, Ontario. International Association of Sedimentologists, p. 10.

Smoot, J.P. and Olsen, P.E. 1985. Massive mudstones in basin analysis and paleoclimatic interpretation of the Newark Supergroup. U.S. Geological Survey Circular, 946, pp. 29-33.

Smoot, J.P. and Olsen, P.E. 1988. Massive mudstones in basin analysis and paleoclimatic interpretation of the Newark Supergroup. In Triassic-Jurassic rifting, continental breakup and the origin of the Atlantic Ocean and passive margins. Part A. Edited by W. Manspeizer. Elsevier, New York, pp. 249-274. http://dx.doi.org/10.1016/B978-0444-42903-2.50015-4

Spielmann, J.A., Lucas, S.G., Rinehart, L.F., and Heckert, A.B. 2008. The Late Triassic archosauromorph Trilophosaurus. New Mexico Museum of Natural History \& Science Bulletin, 43, pp. 1-177.

Steinthorsdottir, M., Jeram, A.J., and McElwain, J.C. 2011. Extremely elevated $\mathrm{CO}_{2}$ at the Triassic/Jurassic boundary. Palaeogeography, Palaeoclimatology, Palaeoecology, 308, pp. 418-432. http://dx.doi.org/10.1016/j.palaeo.2011. 05.050

Stevens, G.R. 1980. Mesozoic volcanism and structure northern Bay of Fundy region, Nova Scotia. Geological and Mineralogical Associations of Canada, 1980, Halifax, Nova Scotia, Annual Meeting, Field Trip Guidebook, Trip 8. Halifax, Nova Scotia, $41 \mathrm{p}$.

Stevens, G.R. 1987. Jurassic basalts of the northern Bay of Fundy region, Nova Scotia. In Northeastern Section of the Geological Society of America: centennial field guide. Edited by D.C. Roy. Volume 5. Geological Society of America, Boulder, Colorado, pp. 415-420. http://dx.doi. org/10.1130/0-8137-5405-4.415

Sues, H.-D. 1985. First record of the tritylodontid Oligokyphus (Synapsida) from the Lower Jurassic of western North America. Journal of Vertebrate Paleontology, 5, pp. 328335. http://dx.doi.org/10.1080/02724634.1985.10011869

Sues, H.-D. 2003. An unusual new archosauromorph reptile from the Upper Triassic Wolfville Formation of Nova Scotia. Canadian Journal of Earth Sciences, 40, pp. 635649. http://dx.doi.org/10.1139/e02-048

Sues, H.-D. and Baird, D. 1998. Procolophonidae (Amniota: Parareptilia) from the Upper Triassic Wolfville Formation of Nova Scotia, Canada. Journal of Vertebrate 
Paleontology, 18, pp. 525-532. http://dx.doi.org/10.1080/ 02724634.1998.10011079

Sues, H.-D. and Fraser, N.C. 2010. Triassic life on land: the great transition. Columbia University Press, New York, $236 \mathrm{p}$.

Sues, H.-D. and Hopson, J.A. 2010. Anatomy and phylogenetic relationships of Boreogomphodon jeffersoni (Cynodontia: Gomphodontia) from the Upper Triassic of Virginia. Journal of Vertebrate Paleontology, 30, pp. 12021220. http://dx.doi.org/10.1080/2724634.2010.483545

Sues, H.-D. and Reisz, R.R. 2008. Anatomy and phylogenetic relationships of Sclerosaurus armatus (Amniota: Parareptilia) from the Buntsandstein (Triassic) of Europe. Journal of Vertebrate Paleontology, 28, pp. 1031-1042. http://dx.doi.org/10.1080/0272-4634-28.4.1031

Sues, H.-D. and Schoch, R.R. 2013. Anatomy and phylogenetic relationships of Calamops paludosus (Temnospondyli: Stereospondyli) from the Triassic of the Newark basin, Pennsylvania. Journal of Vertebrate Paleontology, 33, pp. 1061-1070. http://dx.doi.org/10.10 80/02724634.2013.759120

Sues, H.-D., Hopson, J.A., and Shubin, N.H. 1992. Affinities of ?Scalenodontoides plemmyridon Hopson, 1984 (Synapsida: Cynodontia) from the Upper Triassic of Nova Scotia. Journal of Vertebrate Paleontology, 12, pp. 168171. http://dx.doi.org/10.1080/2724634.1992.10011447

Sues, H.-D., Shubin, N.H., and Olsen, P.E. 1994. A new sphenodontian (Lepidosauria: Rhynchocephalia) from the McCoy Brook Formation (Lower Jurassic) of Nova Scotia, Canada. Journal of Vertebrate Paleontology, 14, pp. 327-340. http://dx.doi.org/10.1080/02724634.1994.1 0011563

Sues, H.-D., Shubin, N.H., Olsen, P.E., and Amaral, W.W. 1996. On the cranial structure of a new protosuchid (Archosauria: Crocodyliformes) from the McCoy Brook Formation (Lower Jurassic) of Nova Scotia, Canada. Journal of Vertebrate Paleontology, 16, pp. 34-41. http:// dx.doi.org/10.1080/02724634.1996.10011281

Sues, H.-D., Olsen, P.E., Scott, D.M., and Spencer, P.S. 2000. Cranial osteology of Hypsognathus fenneri, a latest Triassic procolophonid reptile from the Newark Supergroup of eastern North America. Journal of Vertebrate Paleontology, 20, pp. 275-284. http://dx.doi. org/10.1671/0272-4634(2000)020[0275:COOHFA]2.0. $\mathrm{CO} ; 2$

Sues, H.-D., Hook, R.W., and Olsen, P.E. 2013. Donald Baird and his discoveries of Carboniferous and early Mesozoic vertebrates in Nova Scotia. Atlantic Geology, 49, pp. 90103. http://dx.doi.org/10.4138/atlgeol.2013.004

Sulej, T. 2007. Osteology, variability, and evolution of Metoposaurus, a temnospondyl from the Late Triassic of Poland. Palaeontologia Polonica, 64, pp. 29-139.

Tanczyk, E.I. 1988. Paleomagnetic investigations on the Îles de la Madeleine, Gulf of St. Lawrence. Geological Survey of Canada Paper, 88-1B, pp. 79-89.

Tanner, L.H. 1996. Formal definition of the Lower Jurassic McCoy Brook Formation, Fundy Rift Basin, eastern Canada. Atlantic Geology, 32, pp. 127-135.

Tanner, L.H. 2006. Synsedimentary seismic deformation in the Blomidon Formation (Norian-Hettangian), Fundy basin, Canada. In The Triassic-Jurassic terrestrial transition. Edited by J.D. Harris, S.G. Lucas, J.A. Spielmann, M.G. Lockley, A.R.C. Milner, and J.I. Kirkland. New Mexico Museum of Natural History \& Science Bulletin, 37, pp. 35-42.

Tanner, L.H. and Hubert, J.F. 1991. Basalt breccias and conglomerates in the Lower Jurassic McCoy Brook Formation, Fundy basin, Nova Scotia: differentiation of talus and debris-flow deposits. Journal of Sedimentary Petrology, 61, pp. 15-27.

Tanner, L.H. and Kyte, F.T. 2005. Anomalous iridium enrichment in sediments at the Triassic-Jurassic boundary, Blomidon Formation, Fundy basin, Canada. Earth and Planetary Science Letters, 240, pp. 634-641. http://dx.doi.org/10.1016/j.epsl.2005.09.050

Tanner, L.H., Hubert, J.F., Coffey, B.P., and McInerney, D.P. 2001. Stability of atmospheric $\mathrm{CO}_{2}$ levels across the Triassic/Jurassic boundary. Nature, 411, pp. 675-677. http://dx.doi.org/10.1038/35079548

Tanner, L.H., Kyte, F.T., and Walker, A.E. 2008. Multiple Ir anomalies in uppermost Triassic to Jurassic-age strata of the Blomidon Formation, Fundy basin, eastern Canada. Earth and Planetary Science Letters, 274, pp. 103-111. http://dx.doi.org/10.1016/j.epsl.2008.07.013

Van Helden, B.G.T. 1986. Palynology: Irving Chevron et al. Cape Spencer No. 1 Well history report D.241. CanadaNova Scotia Offshore Petroleum Board, Halifax, 2 p.

Voigt, S., Hminna, A., Saber, H., Schneider, J.W., and Klein, H. 2010. Tetrapod footprints from the uppermost level of the Permian Ikakern Formation (Argana Basin, Western High Atlas, Morocco). Journal of African Earth Sciences, 57, pp. 470-478. http://dx.doi.org/10.1016/j. jafrearsci.2009.12.003

Voigt, S., Schneider, J.W., Saber, H., Hminna, A., Lagnaoui, A., Klein, H., Brosig, A., and Fischer, J. 2011. Complex tetrapod burrows from the Middle Triassic red beds of the Argana Basin (Western High Atlas, Morocco). Palaios, 26, pp. 555-566. http://dx.doi.org/10.2110/palo.2011.p11$014 \mathrm{r}$

Wade, J.A., Brown, D.E., Traverse, A., and Fensome, R.A. 1996. The Triassic-Jurassic Fundy Basin, eastern Canada: regional setting, stratigraphy and hydrocarbon potential. Atlantic Geology, 32, pp. 189-231.

Weems, R.E. and Olsen, P.E. 1997. Synthesis and revision of groups within the Newark Supergroup, eastern North America. Geological Society of America Bulletin, 109, pp. 195-209. http://dx.doi.org/10.1130/0016-7606(1997) 109<0195:SAROGW>2.3.CO;2 
Weinbaum, J.C. 2011. The skull of Postosuchus kirkpatricki (Archosauria: Paracrocodyliformes) from the Upper Triassic of the United States. PaleoBios, 30, pp. 18-44.

Welles, S.P. 1993. A review of lonchorhynchine trematosaurs (Labyrinthodontia), and the description of a new genus and species of the lower Moenkopi Formation. PaleoBios, 14, pp. 1-24.

White, T.C.R. 2011. The significance of unripe seeds and animal tissues in the protein nutrition of herbivores. Biological Reviews, 86, pp. 217-224. http://dx.doi. org/10.1111/j.1469-185X.2010.00143.x

Whiteside, J.H., Olsen, P.E., Kent, D.V., Fowell, S.J., and EtTouhami, M. 2007. Synchrony between the CAMP and the Triassic-Jurassic mass-extinction event? Palaeogeography, Palaeoclimatology, and Palaeoecology, 244, pp. 345-367. http://dx.doi.org/10.1016/j.palaeo.2006.06.035

Whiteside, J.H., Olsen, P.E., Eglinton, T.I., Brookfield, M.E., and Sambrotto, R.N. 2010. Compound-specific carbon isotopes from Earth's largest flood basalt province directly link eruptions to the end-Triassic mass extinction. Proceedings of the National Academy of Sciences USA, 107, pp. 6721-6725. http://dx.doi. org/10.1073/pnas.1001706107

Whiteside, J.H., Grogan, D.S., Olsen, P.E., and Kent, D.V. 2011. Climatically driven biogeographic provinces of Late Triassic tropical Pangea. Proceedings of the National Academy of Sciences USA, 108, pp. 8972-8977. http:// dx.doi.org/10.1073/pnas.1102473108

Whittle, C.H. and Onorato, L. 2000. On the origins of gastroliths - determining the weathering environment of rounded and polished stones by scanning-electron microscope examination. In Dinosaurs of New Mexico. Edited by S.G. Lucas and A.B. Heckert. New Mexico Museum of Natural History \& Science Bulletin, 17, pp. 69-73.

Wild, R. 1973. Die Triasfauna der Tessiner Kalkalpen. XXIII. Tanystropheus longobardicus (Bassani) (Neue Ergebnisse). Schweizerische Paläontologische Abhandlungen, 95, pp. $1-162$.

Wild, R. 1980. Die Triasfauna der Tessiner Kalkalpen. XXIV. Neue Funde von Tanystropheus (Reptilia, Squamata). Schweizerische Paläontologische Abhandlungen, 102, pp. $1-43$.

Williams, G.L., Fyffe, L.R., Wardle, R.J., Colman-Sadd, S.P., and Boehner, R.C. (eds.). 1985. Lexicon of Canadian stratigraphy. Volume VI: Atlantic region. Canadian Society of Petroleum Geologists, Calgary, Alberta, 572 p.

Wings, O. 2005. Taphonomy, gastroliths, and the lithophagic behavior of sauropodomorph dinosaurs. Journal of Vertebrate Paleontology, 25 (Suppl. to 3), p. 131A.

Withjack, M.O., Olsen, P.E., and Schlische, R.W. 1995. Tectonic evolution of the Fundy rift basin, Canada: evidence of extension and shortening during passive margin development. Tectonics, 14, pp. 390-405. http:// dx.doi.org/10.1029/94TC03087
Withjack, M.O., Schlische, R.W., and Baum, M.S. 2009. Extensional development of the Fundy rift basin, southeastern Canada. Geological Journal, 44, pp. 631651. http://dx.doi.org/10.1002/gj.1186

Withjack, M.O., Baum, M.S., and Schlische, R.W. 2010. Influence of preexisting fault fabric on inversion-related deformation: a case study of the inverted Fundy rift basin, southeastern Canada. Tectonics, 29, TC6004, 22 p. http:// dx.doi.org/10.1029/2010TC002744

Wotzlaw, J.F., Guex, J., Bartolini, A., Gallet, Y., Krystyn, L., McRoberts, C.A., Taylor, D., Schoene, B., and Schaltegger, U. 2014. Towards accurate numerical calibration of the Late Triassic: high-precision $\mathrm{U}-\mathrm{Pb}$ geochronology constraints on the duration of the Rhaetian. Geology, 42, pp. 571-574. http://dx.doi.org/10.1130/G35612.1

\section{APPENDIX}

\section{Type sections for members of formations of the Fundy Group in the Fundy rift basin}

The establishment of the new members is intended to follow the North American Stratigraphic Code (NACSN 2005). These members were first introduced as informal subdivisions in Olsen et al. (2000) and used in subsequent papers (e.g., Olsen et al. 2003b, 2005a, b; Olsen and EtTouhami 2008). The geographic coordinates for many of the localities cited here were obtained using Google Earth or an iPhone $4 \mathrm{~s}$ for which the datum is WGS84, which is very similar to NAD83.

\section{New members}

\section{Economy Member of the Wolfville Formation}

The Economy Member of the Wolfville Formation is herein named for the community of Economy, Colchester County, Nova Scotia and is based on the shore and foreshore outcrops between Lower Economy and Carrs Brook, Colchester County, Nova Scotia between approximately $45.3962^{\circ} \mathrm{N}, 63.9582^{\circ} \mathrm{W}$ and $45.3963^{\circ} \mathrm{N}, 63.9654^{\circ} \mathrm{W}$. The type section was measured at $45.3961^{\circ} \mathrm{N}, 63.9608^{\circ} \mathrm{W}$ and published by Olsen (1997, fig. 11).

Based on distinctive lithologies present at the site producing the faunal assemblage discovered by Baird and first reviewed by Olsen (1988), the informal term "Lower Economy beds" was coined by Olsen and Flynn (1989) and used by Huber et al. (1993) for the steeply dipping strata outcropping near Lower Economy, Colchester County, Nova Scotia, and the assemblage from these strata formed the basis of the latter's Economian Land Vertebrate Faunachron. Olsen (1997) referred to these same strata at the same 
outcrops as the "Economy beds" and "Lower Economy beds" and provided a measured section (modified here in Fig. A1). Although Olsen (1997) assigned these beds to TS I, they should be assigned to TS II as corrected in subsequent papers (e.g., Olsen et al. 2000, 2003b). Olsen et al. (2000) informally named these beds the "Economy member" and recognized it as the basal part of TS II in the Fundy Basin.

As defined here and visible at its type section, the Economy Member consists of red and brown largely clastic rocks comprising metre-scale lithic and intraformational conglomerate and sandstone beds with trough cross-bedding, often overlain by red sandy mudstones. The intraformational conglomerate and some lithic conglomerates are often matrix-poor and cemented with calcite. Generally these calcite-cemented units contain tetrapod bones as clasts. Many of the sandstone and mudstone units are intensely bioturbated. Interbedded in the section are tabular and laterally continuous red mudstones and claystones with interbedded tabular sandstones interpreted as lacustrine intervals, as well as significant well sorted orange quartzitic sandstones with dune-scale cross-bedding interpreted as

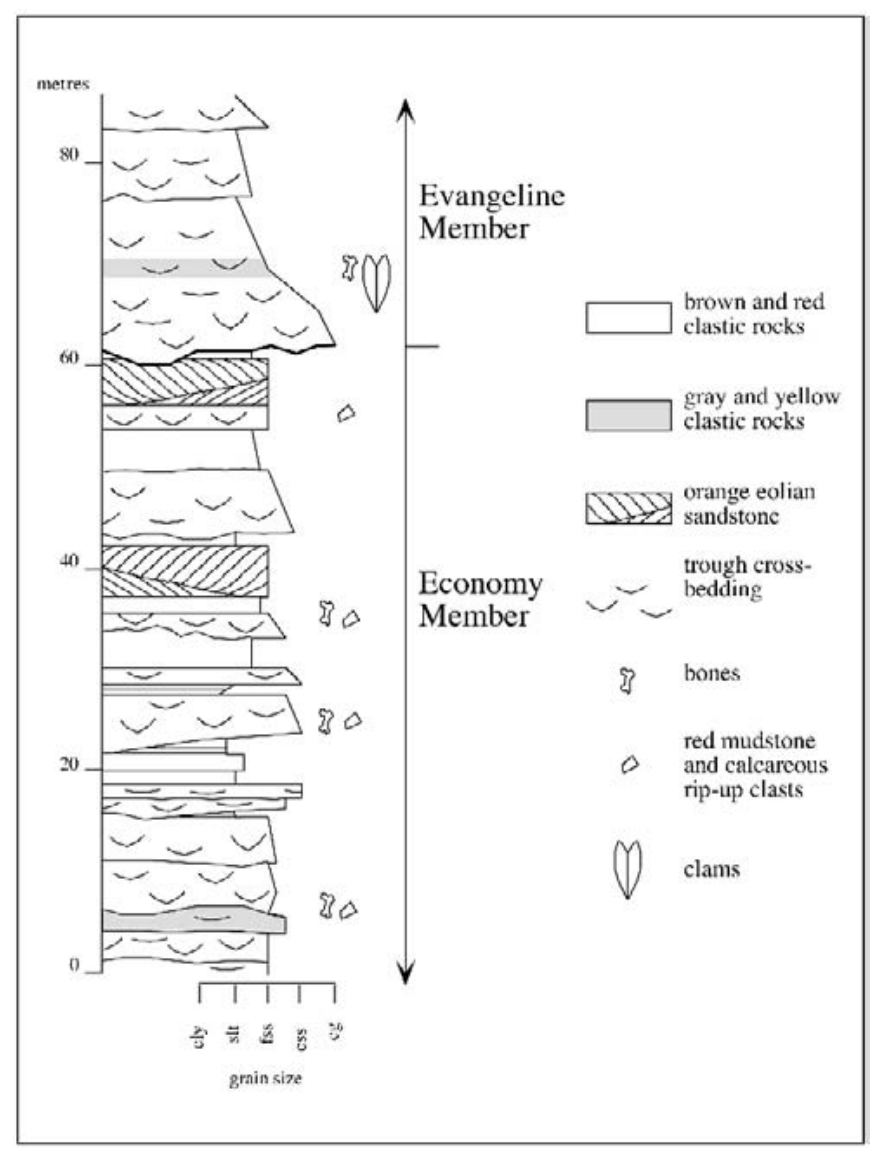

Figure A1. Type section of the Economy Member at Carrs Brook, Nova Scotia. Modified from Olsen (1997). aeolian dunes.

The lower boundary of the Economy Member is locally an unconformity on pre-Late Permian strata, which is not seen at the type section, but is seen on the south shore of the Minas Basin. There, at Half Moon Bay, Leleu et al. (2010) identified sections similar to the type section, and the strongly angular unconformity with Carboniferous strata is visible there. The quartzitic aeolian sandstones lie near the base of what Leleu et al. (2010) termed middle Wolfville and just above the locally highest conglomerate of the lower Wolfville. We consider that the affinities of the aeolian units that Leleu and her colleagues assigned to the middle Wolfville lie with their lower Wolfville, and hence belong to the Economy Member as defined here. The upper boundary of the Economy Member is here defined as the contact between the uppermost orange quartzitic sandstone with dune-scale bedding and well-rounded quartz grains (interpreted as an aeolian dune facies; Skilliter 1996; Leleu et al. 2010) and overlying red and brown sandstones and conglomerates of the Evangeline Member of the Wolfville Formation (Fig. A1). The Economy Member is at least 60 $\mathrm{m}$ thick at its type section, but may be considerably thicker elsewhere; quantification of its total thickness is limited by exposure and faulting. It is roughly $70 \mathrm{~m}$ thick at Half Moon Bay (Leleu et al. 2010).

As discussed in the main text, the age of the Economy Member is poorly constrained but clearly Triassic and older than most Newark Supergroup strata. It could be as old as Early to Middle Triassic or as young as early Carnian.

\section{Evangeline Member of the Wolfville Formation}

The Evangeline Member of the Wolfville Formation is herein named for Evangeline Beach at Grand Pré, Kings County, Nova Scotia, and based on shore and foreshore outcrops between the shoreline west of the end of Beach road, Grand Pré, Kings County, Nova Scotia, between $45.1344^{\circ} \mathrm{N}, 64.3316^{\circ} \mathrm{W}$ and $45.1365^{\circ} \mathrm{N}$ and $64.3267^{\circ} \mathrm{W}$. The strata in these outcrops comprise the Evangeline Member's stratotype (Fig. A2).

In general, the Evangeline Member comprises the middle of the traditional Wolfville Formation as discussed by Baird and Take (1959), Baird (1963), Baird in Carroll et al. (1972), Baird and Olsen (1983), Olsen (1988), Olsen et al. $(1989,2005 \mathrm{a}, \mathrm{b})$ and Olsen and Et-Touhami (2008). The establishment of the Evangeline Member formalizes the informal terms "Evangeline beds" and "Evangeline member" previously used by Olsen (1997) and Olsen et al. (2003b). In its type area the Evangeline Member is at least $200 \mathrm{~m}$ thick, but probably at least twice that in total thickness in that area, as faulting and covered intervals preclude an accurate assessment. Hubert and Forlenza (1988), Leleu and Hartley (2010) and Leleu et al. $(2009,2010)$ described sections along the Burntcoat-Noel and Evangeline shores, and Leleu et al. 
(2010) described the section from Kingsport to Medford.

The base of the Evangeline Member is defined as the contact with the uppermost underlying quartzitic (aeolian dune) sandstone of the Economy Member. Its upper boundary is formed by the unconformity or correlative conformity with the overlying Red Head Member of the Blomidon Formation. That contact is likely exposed within the Kingsport to Medford section that has been described by Leleu et al. (2010), showing up as a change in strike rather than a change in the very low dips.

In contrast with the underlying Economy Member of the Wolfville Formation and the overlying Red Head Member of the Blomidon Formation, the Evangeline Member has no obvious aeolian sandstones and has much more bioturbation, especially by roots, and on the whole is less variable in fluvial facies.

Based on the presence of Metoposaurus bakeri, the Evangeline Member is late Carnian in age, but confirmation from other evidence is needed.

\section{Red Head Member of the Blomidon Formation}

The Red Head Member of the Blomidon Formation is named for its type section at Red Head, Colchester County, Nova Scotia $\left(45.3836^{\circ} \mathrm{N}, 64.0385^{\circ} \mathrm{W}\right)$. Shore cliff and foreshore outcrops of the type section consist of orange-tobrown cross-bedded sandstones with interbeds of gravelly sandstone and tabular mudstone and sandstone. The informal names "Red Head beds" (Olsen 1997) and "Red Head member" (Olsen et al. 2003b) have previously been used for the same interval. The type section is $32.5 \mathrm{~m}$ thick and was described by Hubert and Mertz (1984, fig. 9). The age of the Red Head Member appears to be middle to late Norian, approximately $214 \mathrm{Ma}$ according to Kent and Olsen (2000).

The Red Head Member, as defined here, comprises the basal part of the Blomidon Formation. Strata here designated as the Red Head Member were not separated from the Wolfville Formation by earlier authors (e.g., Hubert and Mertz 1984) because they have a higher frequency of coarser-grained units in contrast to the comparatively finegrained portions of the Blomidon Formation. However, not only does the overall lithology (not just grain size) and facies of the Red Head Member differ dramatically from the underlying Wolfville Formation but it is also intimately interbedded with more typical Blomidon-like facies in sections contiguous with the type section (Fig. A3). The Red Head Mamber is separated from the Wolfville (as now defined) at least locally by a significant unconformity (TS II - TS III unconformity), and in some outcrops the Wolfville Formation is absent, so that Red Head Member rests directly on Carboniferous strata (Fig. A3).

The base of the Red Head Member is defined as the unconformity or correlative conformity with the underlying

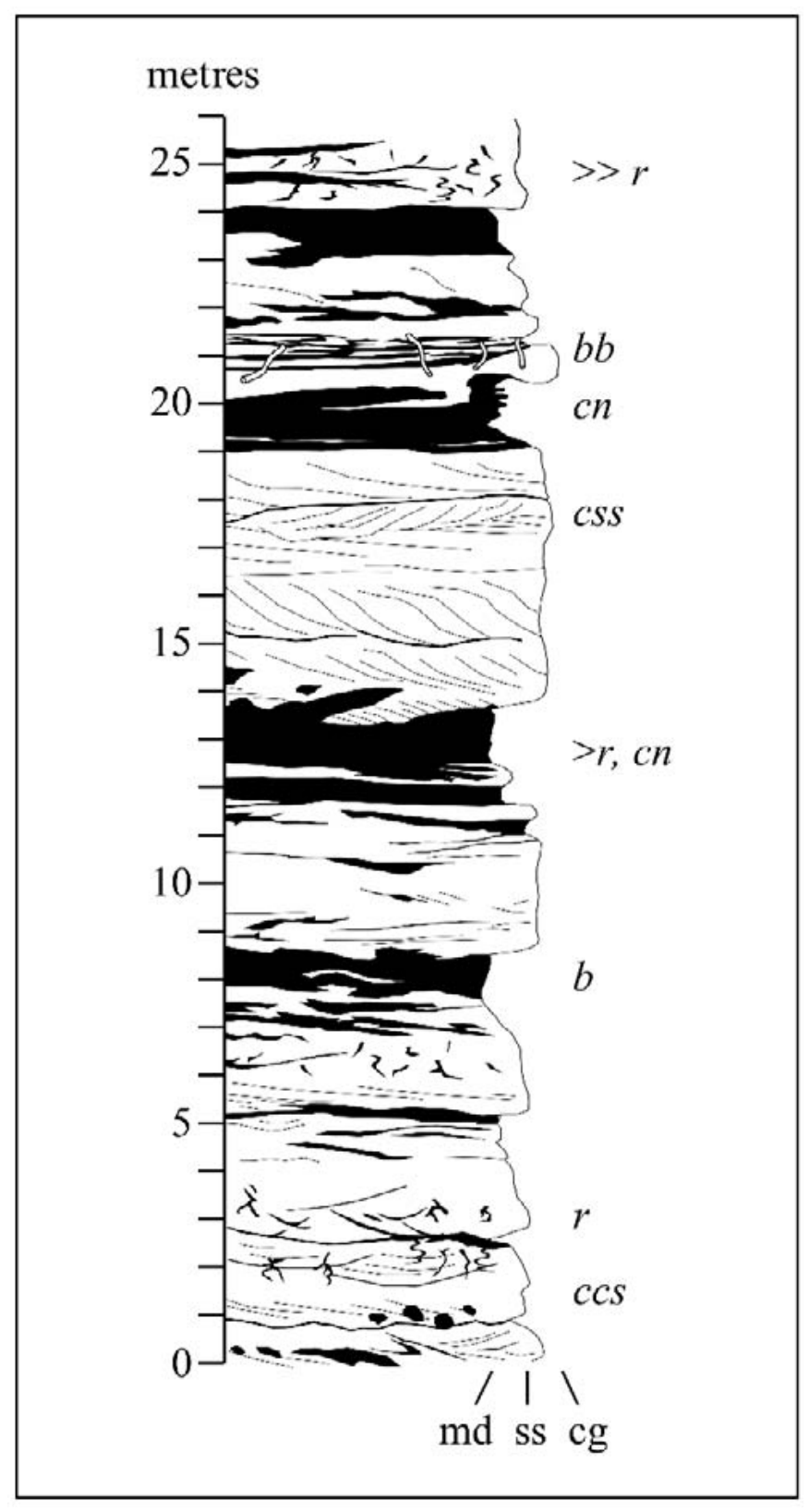

Figure A2. Type section of the Evangeline Member. Abbreviations: b, burrows, bb, big burrows; ccs, conchostracans; cn, carbonate nodules; css, calcitecemented, largely mud-clast conglomerate; r, 'ropy' calcareous rhizoliths.

Wolfville Formation or older units (such as Carboniferous strata) and is marked by a transition into less bioturbated sandstones and the presence of well-sorted cross-bedded sandstones interpreted as aeolian. The basal unconformity is strongly angular on the north shore of the Minas Basin in the vicinity of the type section at two sets of outcrops: one in the foreshore at Pinnacle Island $\left(45.3784^{\circ} \mathrm{N}, 64.1266^{\circ} \mathrm{W}\right)$, 
described by Olsen and Et-Touhami (2008), and the other in the foreshore at Lower Economy $\left(45.3962^{\circ} \mathrm{N}\right.$, $63.9716^{\circ} \mathrm{W}$ ) described in detail by Withjack et al. (2009). The unconformity is also evident in the Consolidated Beacon Resources Ltd. Line 10 seismic profile described by Withjack et al. (2010) over the Economy peninsula. On the south side of Pinnacle Island (Fig. 6B), sandstones and gravelly sandstone of the Red Head Member are well exposed in the cliffs and in the foreshore (accessible at low tide), and they rest with a profound unconformity upon truncated Wolfville Formation sandstones and gravels. At Pinnacle Island, the basal part of the Blomidon Formation strikes about $270^{\circ}$ to $300^{\circ}$ and dips about $35^{\circ}$ to $40^{\circ} \mathrm{N}$, whereas the Wolfville Formation strikes about $340^{\circ}$ to $360^{\circ}$ and dips about $20^{\circ} \mathrm{E}$. This is probably the best area to see the TS II - TS III unconformity in the Fundy basin. Withjack et al. (2009) described less well-exposed outcrops of the unconformity on the cliffs and foreshore at Lower Economy. There, basal conglomeratic sandstones of the Red Head Member, gently dipping $16^{\circ}$ west-southwest, rest unconformably on the Upper Carboniferous Mabou Group (Fig. A3) on the shore. However, in the foreshore, where the Red Head Member dips $20^{\circ}$ west and strikes $171^{\circ}$, it rests with a highly angular unconformity on Wolfville strata that dip on average about $57^{\circ}$ south-southeast and strike $111^{\circ}$ (Withjack et al. 2009, fig. 11a). In both situations at Lower Economy, seaweed obscures the facies of the Wolfville Formation, and it is unclear if strata in contact with the Red Head Member belong to the Economy Member or the Evangeline Member. It may be that the strong discordance at these two outcrops is due to syn-Triassic salt tectonics or some other tectonic mechanism.

The unconformable contact between the Red Head Member of the Blomidon Formation and the underlying Evangeline Member of the Wolfville Formation outcrops on the south shore of the Minas basin in the Kingsport to Medford section described by Leleu and Hartley (2010). It is evident as an approximately $25^{\circ}$ change in bedding strike visible in the foreshore (at about $45.1877^{\circ} \mathrm{N}, 64.3526^{\circ} \mathrm{W}$ ) with the contact between underlying beds striking about $250^{\circ}$ (dipping about $4^{\circ} \mathrm{NW}$ ) and overlying beds striking $225^{\circ}$ (dipping about $3^{\circ} \mathrm{NW}$ ), projecting into the cliff outcrops at the $150 \mathrm{~m}$ mark in Leleu and Hartley's (2010) section (field checked on 3 July 2013). Below this level, there is abundant purple mottling, large rhizomorphs and rhizoliths, and differential cementation including calcitecemented intraformational conglomerate, and no beds of aeolian sandstone. Above this level are beds of aeolian sandstone visible in the cliff face (Leleu and Hartley, 2010) with at least one in the foreshore (notably at $45.189019^{\circ} \mathrm{N}$, $64.351265^{\circ} \mathrm{W}$ ), there is virtually no color mottling, no large rhizomorphs or rhizoliths nor calcite-cemented intraformational conglomerate, all of which are consistent with the upper beds being part of the Red Head Member

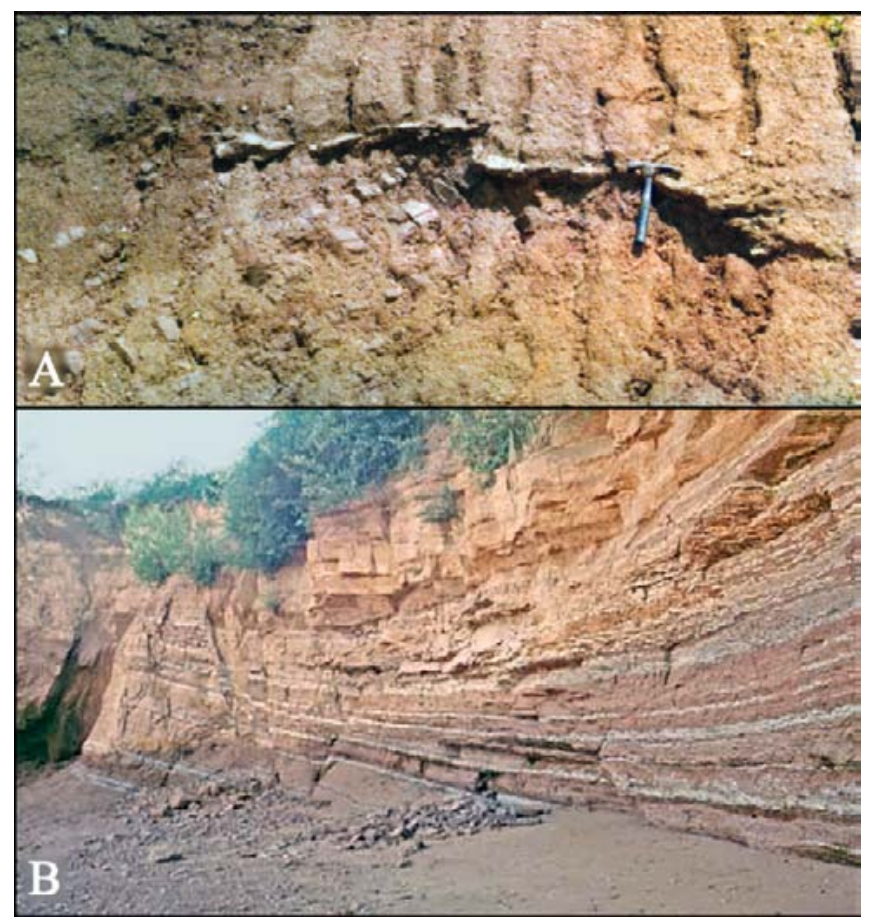

Figure A3. (A) Sedimentary breccia of the Red Head Member resting with an angular unconformity on red beds of the Carboniferous Mabou Group, Lower Economy, Colchester County $\left(45.3993^{\circ} \mathrm{N}, 63.9736^{\circ} \mathrm{W}\right)$. The strata of both the Red Head Member and Mabou Group dip northwest, but the latter dip more steeply. Note that the unconformity is an onlap in Red Head bedding plane coordinates. (B) Red Head Member with interbedded mudstones comparable to the White Water Member, Lower Economy, Colchester County $\left(45.3949^{\circ} \mathrm{N}, 63.9935^{\circ} \mathrm{W}\right)$.

of the Blomidon Formation, and the lower beds belonging to the Evangeline Member of the Wolfville Formation. Consequently, the Red Head Member is about $80 \mathrm{~m}$ thick in this area based on the section in Leleu and Hartley (2010).

The Red Head Member has been identified at its type area, the Economy peninsula, the Medford area, and in the subsurface in the GAV-3 core (Kent and Olsen 1999) and the Chinampas N-37 and Cape Spencer P-79 wells (as identified in cuttings by PEO) (Fig. A4). Maximum thickness of the Red Head Member in outcrop is in excess of $100 \mathrm{~m}$ as seen at Economy Mountain (Hubert and Mertz 1984), and it may be much thicker in the Bay of Fundy as seen in the Chinampas N-37 and Cape Spencer P-79 wells, where it may be up to 620 and $446 \mathrm{~m}$ thick, respectively - although it is difficult to identify the member accurately using cuttings and so these estimates are uncertain.

The marked decrease in bioturbation, the appearance of extensive aeolian dune sandstones, and the interbedded strata of mudstones with sand-patch fabric (see below) are 
indicative of a more arid climatic regime for the Red Head Member than the underlying Wolfville. The reduction in bioturbation is responsible for the better preservation of mud-cracked bedding plane surfaces and most likely for the abundant tetrapod tracks typical of the unit in the Paddy Island - North Medford area.

\section{White Water Member of the Blomidon Formation}

We designate the cyclical mudstone and sandstone sequence exposed mostly in the sea cliffs from $45.2554^{\circ} \mathrm{N}$, $64.3512^{\circ} \mathrm{W}$ (Borden Brook, White Water) to $45.2272^{\circ} \mathrm{N}$, $64.3582^{\circ} \mathrm{W}$ (Mill Brook), Blomidon, Kings County, Nova Scotia, as the stratotype of the White Water Member of the Blomidon Formation. The stratotype section was described and measured by Olsen et al. (1989, pp. 142-145, figs. 10.410.7), and the name derives from the small community of White Water, Nova Scotia, adjacent to the mouth of Borden Brook as it opens onto the tidal flat of the Minas Basin. Olsen et al. (2003b) used the informal name "White Water member", and we formalize the term here. The White Water Member is bounded below by its conformable contact with the Red Head Member of the Blomidon Formation, and above by the conformable contact with the Partridge Island Member of the Blomidon Formation.

The White Water Member is almost entirely composed of sedimentary cycles exhibiting a characteristic facies called "sand-patch massive mudstone" first recognized by Smoot and Castens-Seidel (1982) and described for the White Water Member by Smoot and Olsen (1985) in general, and at the stratotype by Smoot and Olsen (1988) and Mertz and Hubert (1990); the last-named authors also described the cycles that characterize the member. In addition to sandpatch cycles, various forms of syn-Blomidon salt-dissolution features are present, including collapse and growth bowls (Olsen and Et-Touhami 2008) and larger-scale brecciation and collapse structures (Olsen et al. 1989; Ackermann et al. 1995; Olsen and Et-Touhami 2008) indicating the former presence of halite beds - but see Tanner (2006) for a different interpretation. Fossils are nearly absent in all but the laminated mudstone facies in these cycles as seen in the area around the Minas Basin and $60 \mathrm{~km}$ to west southwest - as seen in the various Getty Mines cores (e.g., GAV-77-3; Kent and Olsen 2000) (Fig. A4) - where the facies of the White Water Member is very consistent and closely resembles that of the stratotype. However, fossils are much more common in the only other major outcrop of the member, at the cliff and foreshore in Digby County, $143 \mathrm{~km}$ to the southwest of the type section (Hubert and Hyde 1982; Figs. 21-22). There, sand-patch fabric is muted and preservation of bedding features is much more common.

The White Water Member is at least $200 \mathrm{~m}$ thick in the type area, where the total thickness is obscured by faulting and inaccessibility. It is $312 \mathrm{~m}$ thick in the GAV-77-3 core, which is likely a very similar thickness to that of the type area. The White Water Member may have a similar thickness at Five Islands, and even to the west in the Cape Spencer P-79 well (Fig. A4), where it attains a minimum thickness of 292 $\mathrm{m}$ and is coarser-grained and has multiple conglomeratic layers. However, the Member appears to reach its maximum thickness to the southwest, where strata of the Fundy Group overall attain their greatest development (Wade et al. 1996). There, in the Chinampas N-37 well, a minimum of $1157 \mathrm{~m}$ of White Water Member is present (Fig. A4).

Based on the polarity stratigraphy in the GAV-77-3 core and correlation to the Newark basin astrochronology (Kent and Olsen 2000), the age the White Water Member is 213 to 201.6 Ma (middle-late Norian to late Rhaetian).

\section{Partridge Island Member of the Blomidon Formation}

Perhaps the most distinctive sedimentary sequence in the Fundy basin is the metre- to several-metres-thick interval of variegated strata comprising the uppermost Blomidon Formation, which we designate here the Partridge Island Member. The name is derived from Partridge Island, a headland near Parrsboro, Cumberland County, Nova Scotia, connected to the mainland by a tombolo (Fig. A5). The

Figure A4. (following page) Stratigraphic determinations for the major wells and cores in the Fundy basin discussed in this paper. Original units in report on which the depths are based are shown in italics. The interpretation of the MobilGulf Chinampas N-37 well is based on Canadian Stratigraphic Service Ltd Log E-105, Mobil mud log, palynological summary report 8618-M3-6-1, and well cuttings (examined by PEO on 11 September, 2000) archived at the Canada-Nova Scotia Offshore Petroleum Board Geoscience Research Centre (CNOSPB-GRC), Dartmouth. The interpretation of the Irving-Chevron Cape Spencer (no. 1) P-79 well is based on the Canadian Stratigraphic Service Ltd Log E-189, mud log D241, palynological summary reports by R.E. Dunay (1975) and B.G.T. Van Helden (1986) and well cuttings archived at CNSOPB-GRC (examined by PEO on 20 September 2000). The interpretation of and map coordinates for the Getty Mines (Sladen) Margaretsville AV-4 core are based on the core (examined by PEO), diamond-drill log (by D.A. Campbell, 1966), and the map (calibrated using Google Earth) and a report by Comeau (1978), archived at the Nova Scotia Department of Natural Resources Drill Core Library (DNRDCL), Stellarton. The interpretation of the Getty Mines Morden GAC-77-3 core is based on the core at DNRDCL (examined by PEO), Comeau (1978; map coordinates calibrated using Google Earth and map in report archived at DNRDCL), Jong (1985), and Kent and Olsen (2000). 


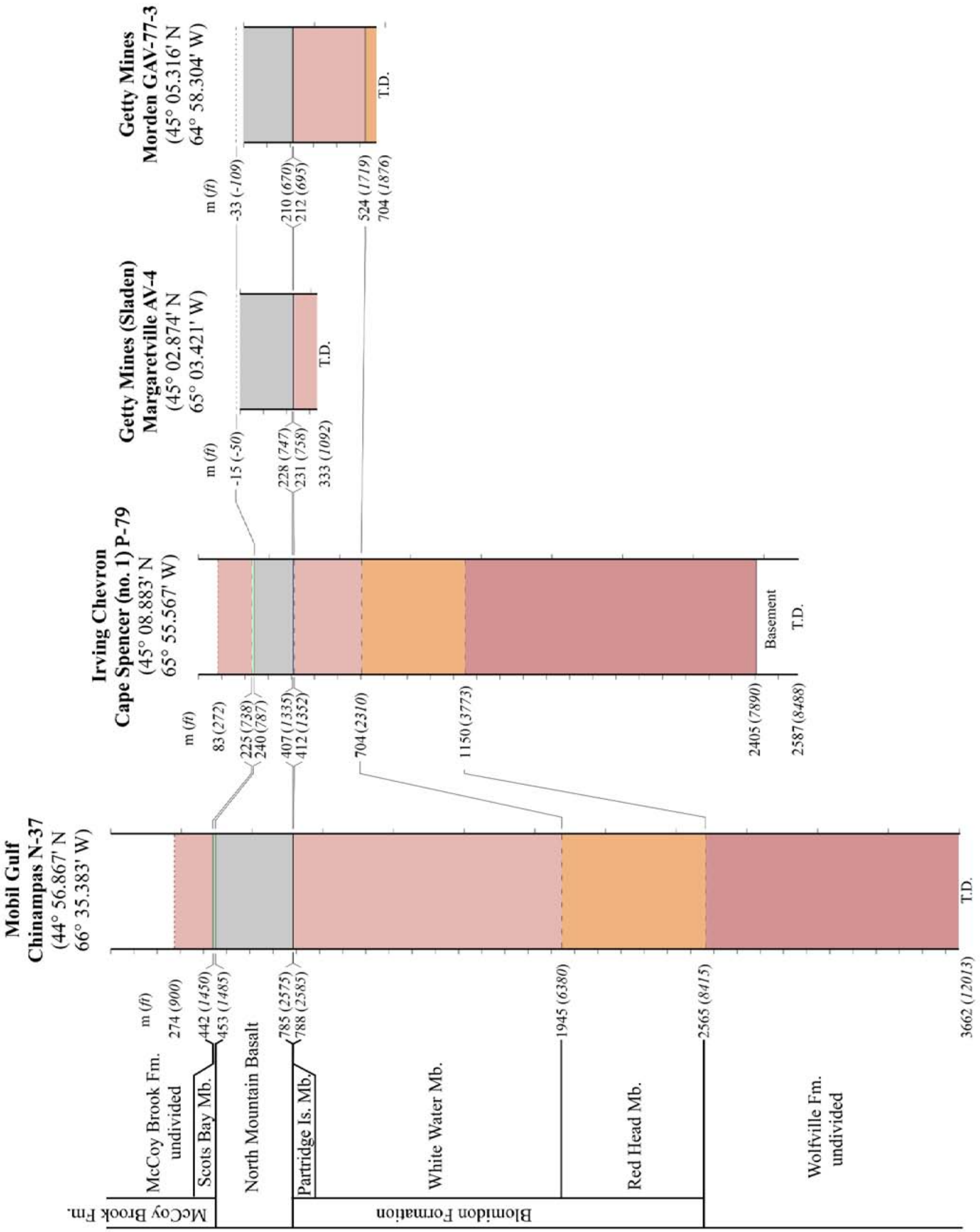


type section is on the northwestern side of Partridge Island $\left(45.2272^{\circ} \mathrm{N}, 64.3582^{\circ} \mathrm{W}\right)$. The informal name "Partridge Island member" was previously used for these strata (Olsen et al. 2003b, Olsen et al. 2005a, b; Olsen and Et-Touhami 2008; Whiteside et al. 2007).

The most distinctive aspect of the member is its variegated nature, generally consisting of alternating layers of red, purple, grey, and black mudstones and calcareous mudstone at decimetre-scale. Where not metamorphosed by the overlying North Mountain Basalt, the grey, black, and even some of the red units contain pollen and spores (Olsen et al. 1987; Fowell and Traverse 1994; Whiteside et al. 2007; Cirilli et al. 2009), and some of the black mudstones have total organic carbon contents in excess of $5 \%$ (Tanner et al. 2008), contrasting with the nearly barren nature of the rest of the Fundy Group. Despite its lateral continuity, however, the member is highly variable laterally, even at the outcrop scale (Fig. A5). This variation is due largely to penecontemporaneous faulting and localized collapse and growth structures related to evaporite growth and dissolution (Olsen and Et-Touhami 2008), as well as faulting related to loading from, and in rheological contrast with, the overlying North Mountain Basalt during the latest Triassic and later.

The boundary between the Partridge Island Member and the underlying White Water Member is defined as the base of the lowest grey to black mudstone between the red beds of the White Water Member and the North Mountain Basalt (Fig. A5). The upper limit of the Partridge Island Member is the contact with the overlying North Mountain Basalt.

Kozur and Weems (2010, p. 351) argued that facies seen at the type section and the member itself, "...occurs only discontinuously beneath the North Mountain Basalt..." Their interpretation is largely based on nearly inaccessible cliff outcrops at Five Islands Provincial Park, where they report "thick paleosols at the top of the Blomidon Formation immediately below the North Mountain Basalt"; they interpret these palaeosols as strong evidence for a major hiatus between the Blomidon Formation and North Mountain Basalt and that the "...Partridge Island Member apparently occupies broad swales cut into the top of the underlying part of the Blomidon Formation."

However, this is demonstrably not the case. Identical facies, and hence the Partridge Island Member, outcrop and subcrop over a large area, and there are no places the member is absent (except very locally due to faults). Outcrops at Cape Sharp $\left(45.3684^{\circ} \mathrm{N}, 64.3911^{\circ} \mathrm{W}\right)$ about $4 \mathrm{~km}$ west of the type section are indistinguishable from the former and were the first to produce palynologically productive samples (collected by PEO and processed by B. Cornet). The same facies, albeit somewhat faulted, is present on Pinnacle Island at Five Islands (Fig. A5), $17 \mathrm{~km}$ to the east of the type section. About $11.5 \mathrm{~km}$ to the south of the type section, facies identical to the type section (contra Kozur and Weems 2010) were temporarily exposed during construction at Blomidon Provincial Park, where the member was measured and sampled on 9 August 1984 (at approximately $45.2630^{\circ} \mathrm{N}$, $64.3379^{\circ} \mathrm{W}$ ) by $\mathrm{M}$. Anders (Columbia University) (Fig. A5) and was found to contain palynomorphs by Bruce Cornet (personal communication). A similar temporary exposure was present in a drainage ditch on the north side of Highway 358 (at approximately $45.1934^{\circ} \mathrm{N}, 64.4253^{\circ} \mathrm{W}$ ) during the 1980s, but was not sampled. Another roadside ditch adjacent to a basalt rock quarry near Berwick, Kings County at $45.0833^{\circ} \mathrm{N} 64.7967^{\circ} \mathrm{W}$ exposed slumped but not metamorphosed grey and black mudstone. Getty Minerals core GAV-77-3 recovered characteristic Partridge Island facies at depths from 210 to $212 \mathrm{~m}$, although the core was badly decimated by sampling prior to 6 September 1995 when PEO measured it (Fig. A5). From the original log of this core (Comeau 1978), it is clear that black mudstone was present, as also indicated in the original log of GAV-77-2 (a similarly decimated core, measured by PEO on 28 August 1995). These boreholes are about $59 \mathrm{~km}$ west-southwest of Partridge Island. The most distant locality $(63 \mathrm{~km}$ westsouthwest) with facies unambiguously typical of the type section is seen in the Sladen (Quebec) Margaretville AV-4 core that has excellent recovery through the Partridge Island Member (Figs. A4-A5). The total distance with facies characteristic of the type section is thus at least $83 \mathrm{~km}$ (Margaretville AV-4 to Pinnacle Island), and so the Partridge Island Member can hardly be considered a local facies.

At two places along the north shore of the Minas Basin, the overlying North Mountain Basalt has metamorphosed the Partridge Island Member. The outcrops at Five Islands display a thick $(4-5 \mathrm{~m})$ metamorphic zone. Strata of the Partridge Island Member are altered to a white to purple hornfels virtually devoid of organic matter, as are the underlying few metres of the White Water Member. Kozur and Weems (2010) interpreted these white to purple strata as a palaeosol without providing details (Fig. A5). The section contains numerous small faults (Withjack et al. 2010) that, seen from beach level, create the appearance due to parallax that the metamorphic interval is locally cut out, although it can be observed from a great distance or by air that this is not the case. The inaccessible nature of the section has made measuring a section practically impossible

Figure A5. (following page) Examples of lateral variations in Partridge Island Member, including the type section. Coordinates given in text. Partridge Island type section from Whiteside et al. (2007) with palaeomagnetic polarity stratigraphy from Deenen et al. (2011); Central Clarence section modified from Olsen and Et-Touhami (2008). 


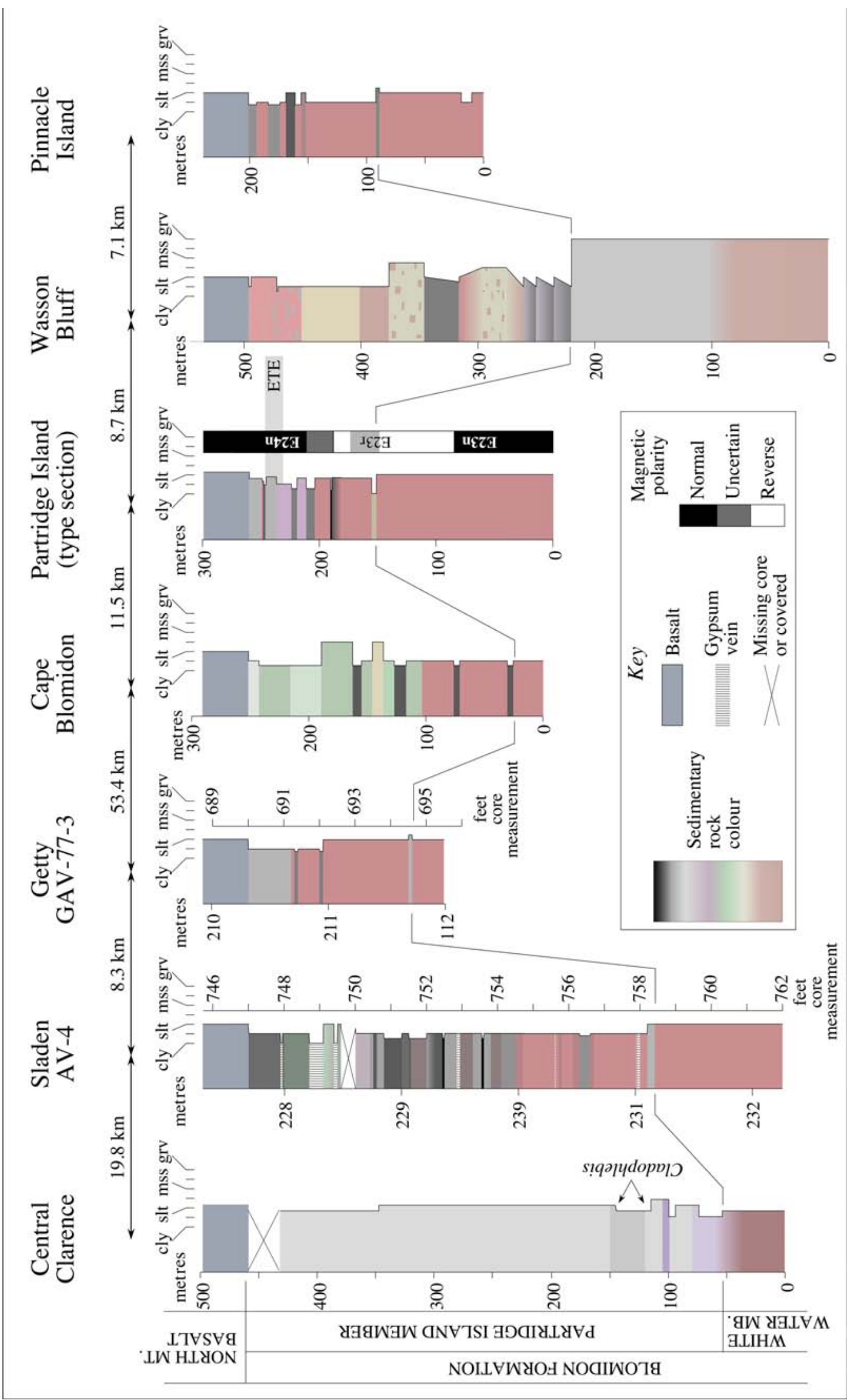


(Fig. A5). A second location with metamorphosed strata of the Partridge Island Member is at Clarke Head, Green Hill, Cumberland County $\left(45.3788^{\circ} \mathrm{N}, 64.2605^{\circ} \mathrm{W}\right)$, where deposits of this member are slightly conglomeratic and extensively faulted. At this location the Partridge Island Member is again represented by a white to purple hornfels. There is no palaeosol at either locality, nor is there physical evidence of a hiatus.

Facies similar to that of the type section of the Partridge Island Member may also be present in the subsurface below the main Bay of Fundy (Fig. A5). Cuttings from the Chinampas N-37 well indicate the presence of thin grey units at $2580 \mathrm{~m}$ (examined on 11 July 2000), and the cuttings from the Cape Spencer P-79 well contained darkgrey mudstone chips at $410 \mathrm{~m}$ (examined on 20 July 2000); both cores are archived at the Canada-Nova Scotia Offshore Petroleum Board Geoscience Research Centre (CNOSPBGRC), Dartmouth, Nova Scotia. While consistent with the facies seen at the type section of the member, the sparse cuttings do not allow for a detailed comparison.

The variegated nature of the Partridge Island Member persists laterally into coarser, even conglomeratic facies as exposed at Wasson Bluff $\left(45.3940^{\circ} \mathrm{N}, 64.2310^{\circ} \mathrm{W}\right.$; Fig. A5), east of McKay Head $\left(45.3982^{\circ} \mathrm{N}, 64.1928^{\circ} \mathrm{W}\right)$ and Blue Sac $\left(45.4040^{\circ} \mathrm{N}, 64.1127^{\circ} \mathrm{W}\right)$, where it is very thin along the Cobequid-Chedabucto fault system, but also along the strike of the basin, notably at Central Clarence $\left(44.9092^{\circ} \mathrm{N}\right.$, $65.2174^{\circ} \mathrm{W}$; Fig. A5). At the latter location the member is an unusually thick (about $4 \mathrm{~m}$ ), predominately white sandstone and pale-grey to cream-coloured mudstone and produces the only plant macrofossils in the Blomidon Formation, consisting almost entirely of the filicalean fern Cladophlebis (Baird in Carroll et al. 1972; Olsen et al. 2005a, b ; Olsen and Et-Touhami 2008). Apparent metamorphism has removed most of the organic matter from these beds, although some pollen can still be found in residues following treatment with hydrofluoric acid, although it is seemingly too fragile to be recoverable (PEO, personal observation). This section is particularly interesting because Armstrong and Besancon (1970) published a K-Ar age of $195 \pm 4 \mathrm{Ma}$, from what they reported as a biotite-bearing ash there - if there is indeed an ash (as opposed to a reset age), it deserves further study. Further southwest along strike, towards Annapolis Royal, Digby County, a quarry at $44.7839^{\circ} \mathrm{N}, 65.5076^{\circ} \mathrm{W}$ reveals poor exposures of the Partridge Island Member, more closely resembling the type section but thicker and with fewer dark grey intervals (section found too poorly exposed to measure on 6 July 2008). Further to the westsouthwest, at its westernmost occurrence yet known, the Partridge Island Member appears metamorphosed as at an access road to a quarry near Roxville, Digby County at $44.6191^{\circ} \mathrm{N}, 65.8400^{\circ} \mathrm{W}$ (observed on 25 July 2001 ), where it is conglomeratic.

The relative and numerical age of Partridge Island member is especially well constrained and has played a key role in debates about the nature of the Triassic-Jurassic transition in eastern North America - a prime motivation for formally naming the unit, in addition to its distinctive lithology. The palynoflora of the type section of the member has been independently analyzed three times with the same results (Fowell and Traverse 1994; Whiteside et al. 2007; Cirilli et al. 2009). Preservation of pollen and spores is good, and, in all three studies, the last occurrences of the vessicate pollen taxon Patinasporites densis are roughly 20 $\mathrm{cm}$ from the top of the member, marking the onset of the palynological end-Triassic extinction. When it could be argued that the Triassic-Jurassic boundary occurred at the onset of the marine extinction and associated geochemical events (e.g., Poole 1979; Golebiowski and Braunstein 1988; Hesselbo et al. 2002; McRoberts et al. 2007), it seemed logical to correlate the Blomidon palynological event to this marine extinction (e.g., Olsen et al. 1987, 2002, 2003b). Now, of course, it is recognized that the system and period boundary must correlate to a level higher than the upper portion of the Blomidon Formation (lower part of the McCoy Brook Formation, above the Scots Bay Member) because the new GSSP is defined on the basis of a younger datum, the first appearance of the ammonite Psiloceras spelae tirolicum (Hillebrandt and Krystyn 2009; Hillebrandt et al. 2007, 2009). Thus the Triassic-Jurassic boundary marks not the extinction but rather the beginning of the biotic recovery from that extinction. But the correlation between the strata themselves or the extinction event has not appreciably changed, except that the extinction level and hence the Partridge Island Member are now late Rhaetian in age by definition.

Deenen et al. (2011) found the reverse polarity chron E23r, first identified in the Newark basin (Kent et al. 1995), at the type section at Partridge Island below the palynological extinction level (Fig. A5). In the Newark basin E23r occurs below the palynological extinction level and below the highest known occurrence of the conchostracan Shipingia olseni, a supposedly early Norian index fossil according to Kozur and Weems (2010). This conchostracan was the main evidence for the existence of a major hiatus below and close to the palynological extinction level, which dates to the late Rhaetian. The fact that E23r has the same relative position to the palynological extinction level in both the Newark and Fundy basins (in the Partridge Island Member) and relative to the overlying basalts in the Newark and Fundy basins as well as in the Argana Basin in Morocco (Deenen et al. 2010) would seem to make the likelihood of a major hiatus remote. 